(2) norden 



\section{Promotion of renewable energy in the Nordic countries}

- Opportunities for harmonization of instruments

Juha Ruokonen, Gunnar Aronsen, Anna-Maija Turkama, Kristian Gautesen, Mats Nilsson, Juha Ollikainen \&

Atle Middtun

TemaNord 2008:598 
Promotion of renewable energy in the Nordic countries

- Opportunities for harmonization of instruments

TemaNord 2008:598

(C) Nordic Council of Ministers, Copenhagen 2008

ISBN 978-92-893-1782-5

Print: Ekspressen Tryk \& Kopicenter

Copies: 0

Printed on environmentally friendly paper

This publication can be ordered on www.norden.org/order. Other Nordic publications are available at www.norden.org/publications

Printed in Denmark

Nordic Council of Ministers

Store Strandstræde 18

DK-1255 Copenhagen K

Phone (+45) 33960200

Fax (+45) 33960202

www.norden.org

\section{Nordic Council}

Store Strandstræde 18

DK-1255 Copenhagen K

Phone (+45) 33960400

Fax (+45) 33111870

\section{Nordic co-operation}

Nordic cooperation is one of the world's most extensive forms of regional collaboration, involving Denmark, Finland, Iceland, Norway, Sweden, and three autonomous areas: the Faroe Islands, Greenland, and Åland.

Nordic cooperation has firm traditions in politics, the economy, and culture. It plays an important rol in European and international collaboration, and aims at creating a strong Nordic community in a strong Europe.

Nordic cooperation seeks to safeguard Nordic and regional interests and principles in the global community. Common Nordic values help the region solidify its position as one of the world's most innovative and competitive. 


\section{Contents}

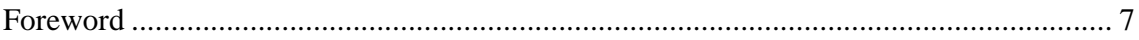

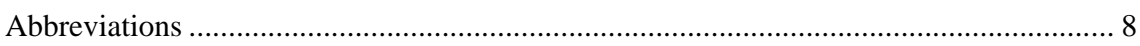

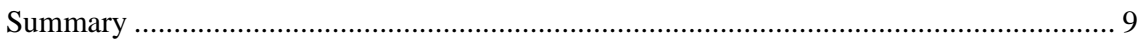

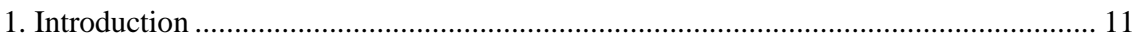

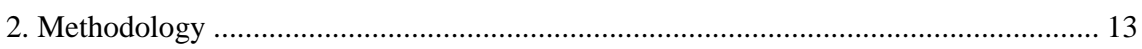

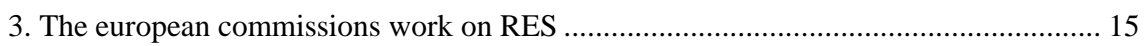

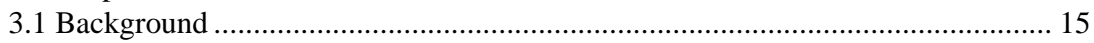

3.2 The Energy and Climate Package......................................................................... 16

3.3 Using Guarantee of Origin trading to meet targets ............................................... 18

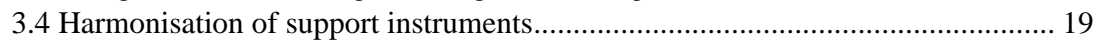

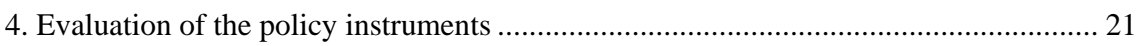

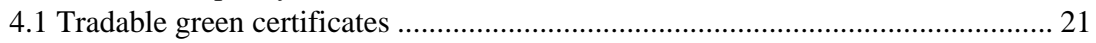

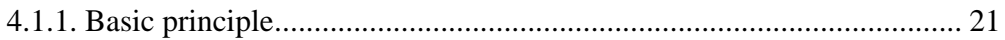

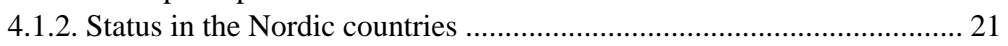

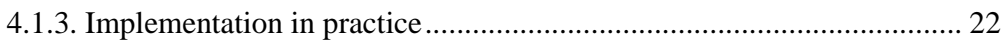

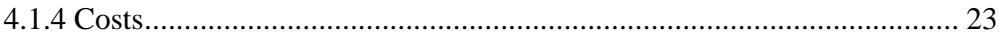

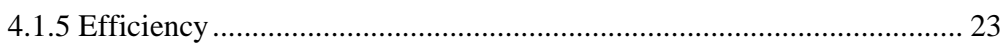

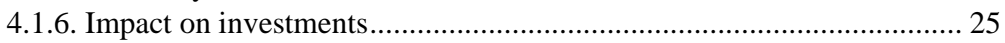

4.1.7. Impact on electricity market and prices................................................ 25

4.1.8 Suitability with other policies............................................................ 26

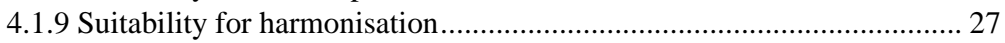

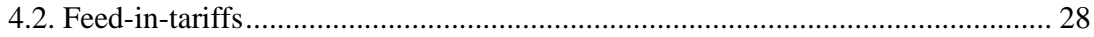

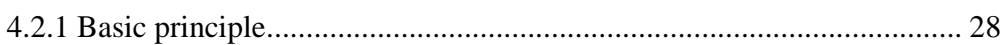

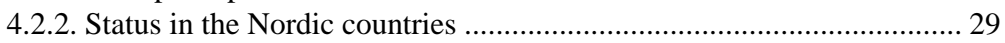

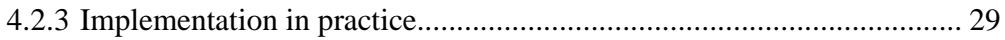

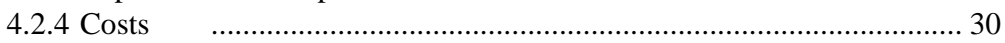

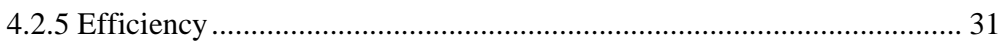

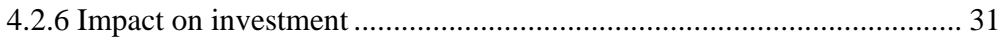

4.3 Other issues - Emissions trading and Guarantee of Origins................................. 34

4.4 Perspectives on harmonised support instruments ................................................... 35

5. Renewable energy in the Nordic countries .................................................................... 39

5.1 Status of RES and targets for 2020 in the Nordic countries ............................... 39

5.1.1 The status of renewable energy support .................................................. 39

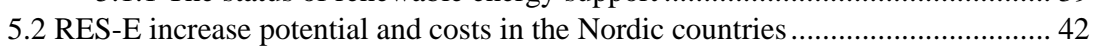

6. Analysis for a harmonised support system in the Nordic countries ............................. 47

6.1 Harmonised versus a non-harmonised solution.................................................. 47

6.2 A technology segmented market solution....................................................... 51

6.3 A harmonised feed-in tariff versus a green certificate scheme ............................. 52

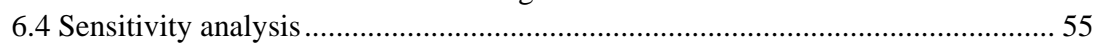

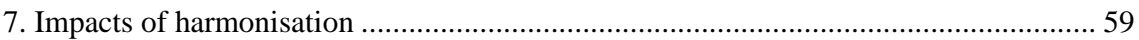

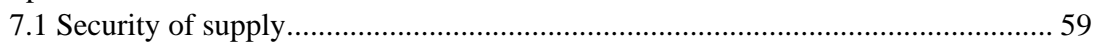

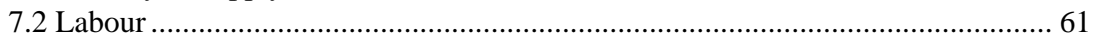

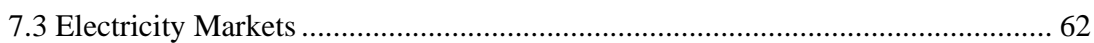

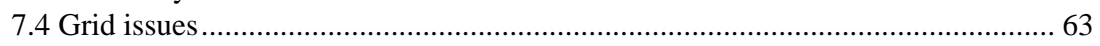

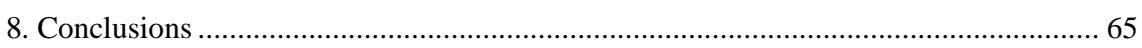

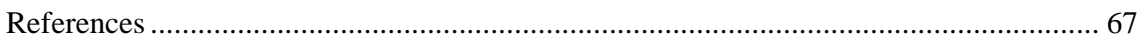




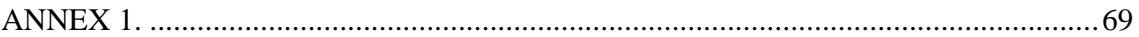

Renewable energy in the Nordic countries .........................................................6 69

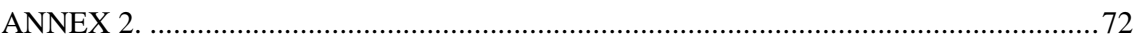

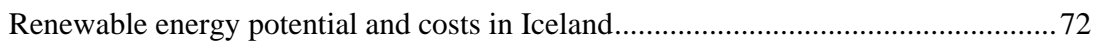

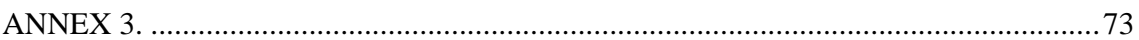

Description for the calculation of the long-run marginal-costs ................................. 73

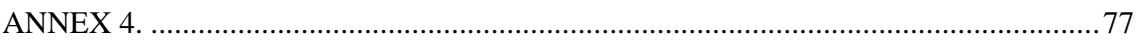

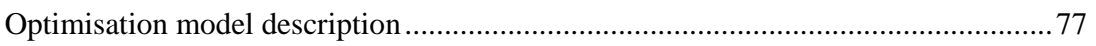

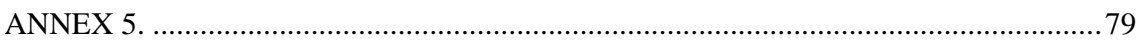

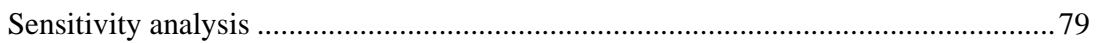

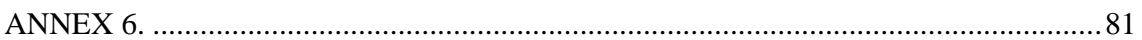

Harmonisation - Comparison on instruments .......................................................... 81

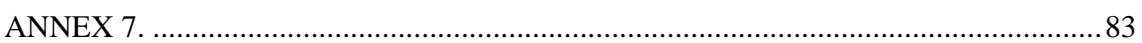

Viewpoint; torstein bye: harmonising instruments -why? ........................................8 83

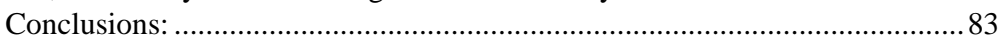

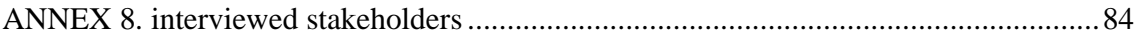

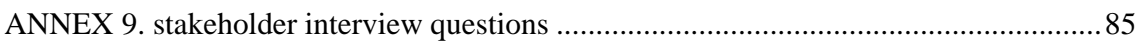

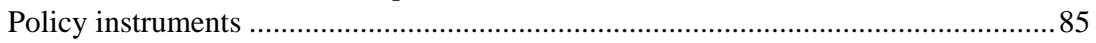

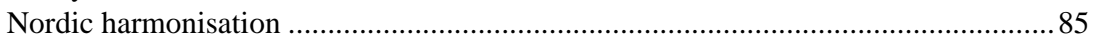

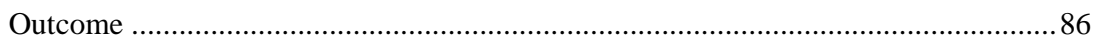

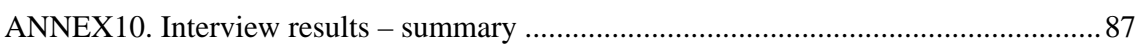




\section{Foreword}

This study was commissioned by the Nordic Working Group for Renewable Energy in January 2008.

The report is based on a literature review, interviews of selected companies and organisations and market expertise and analysis of the GreenStream Network Ltd. The report does not present the opinions of the Working Group for Renewable Energy. All the conclusions presented in the report are those of the authors (see below).

The report has been prepared by Mr. Juha Ruokonen, Mr. Gunnar Aronsen, Ms. Anna-Maija Turkama, Mr. Kristian Gautesen, Mr. Mats Nilsson, Mr. Juha Ollikainen from GreenStream Network Plc and $\mathrm{Mr}$ Atle Middtun from Norwegian School of Management. 


\section{Abbreviations}

$\begin{array}{ll}\text { CHP } & \text { Combined Heat and Power } \\ \text { EC } & \text { European Commission } \\ \text { EU ETS } & \text { European Union Emissions Trading Scheme } \\ \text { GDP } & \text { gross domestic product } \\ \text { GoO } & \text { Guarantee of Origin } \\ \text { IRR } & \text { internal rate of return } \\ \text { LRMC } & \text { long run marginal cost } \\ \text { RES } & \text { renewable energy source } \\ \text { RES-E } & \text { renewable energy source (for) electricity } \\ \text { R\&D } & \text { research and development } \\ \text { TSO } & \text { transmission system operator } \\ \text { WACC } & \text { weighted average cost for capital }\end{array}$




\section{Summary}

Ambitious targets to increase the she share of renewable energy (RES) technologies in energy production has awoken several level discussions on how and with what measures the targets will be reached. Nordic countries as well as other countries must readjust the used support mechanisms as well as the level of support to correspond the required increased targets. This reconsideration has given space for discussion on possible common Nordic support system - an idea that is supported by common electricity market and long co-operation in energy issues.

When comparing the required new RES capacity to the potentials each Nordic country has, it is clear that the Nordic countries can, at least based on the potentials, reach the targets on a national level. Denmark, which has invested significantly to wind power during the last decade, has still some potential to increase wind capacity but a notable share of new RES could be obtained with biomass. In Finland, the potential to increase biomass share is significant but giving the time restriction for the increased obligation, wind is the most promising technology for new capacity. In Norway, the potential to increase RES production is the biggest among Nordic countries. Although the share of renewables is already substantial, the potential for new wind and hydro capacity is vast. In addition, new technologies such as osmotic power (see explanation on footnote number 8) are likely to strengthen Norway's leader's position in RES production in a longer run. Also Sweden is estimated to be able to increase significantly the share of wind capacity. In theory, the Swedish potential is enormous but giving the time scope some restrictions need to be considered. Overall, it is clear that both off- and onshore wind have the most important role in increasing RES in the Nordic countries for the next decade.

Although national potentials exist, an important question is how much the increase is going to cost. Comparison between the Nordic countries showed clear cost differences between the potentials. Based on this, a common Nordic support scheme, built on a market base instrument would lead to more a cost-efficient solution than national measures would. Such harmonised scheme could be for example a common green certificate scheme for electricity based on renewable energy sources. Co-operation between Nordic countries in reaching the RES targets would reduce the overall costs of reaching the targets but on the other hand, investments to new power generation capacity would be unevenly distributed.

The location of new capacity under the harmonised, market based support system differs from the case where there is no harmonisation. Since the wind potentials in Norway and Sweden as well as Norway's 
hydro potential is estimated to be large and available with rather low cost, most of the new capacity would be located in these countries. The position of countries remains the same even if it is assumed that certain amount of bio, hydro and new, developing technologies is built in addition to wind. Under this solution the role of Norway's hydro potential and Sweden's bio potential extends but Finland and Denmark remain to have a minor role in new capacity. Still, the estimated increase potentials are not in every level comparable which gives some ambivalence to the amount of investments each country will have. Still, the cost assumptions are estimated to be in line with general estimates which again give confirmation to the results.

The country wise rather uneven distribution of new electricity production capacity as well as possible high share of wind production raises questions on possible impacts on national security of supply, the functionality of electricity markets, grid connections and the need for new balancing power capacity. Nordic countries will definitely need more grid connections and especially the harnessing of Norway's small hydro potential is going to be a challenge. Due to new investments, the possible labour impacts new capacity has is also a relevant question. New wind capacity building is estimated to bring the biggest impacts and consequently the positive labour impacts will follow the location of new plants. However, at this point, new RES capacity is not expected to have a macro economic significance in labour.

The final formulation of legislation concerning the EU RES obligations is the wild card for harmonisation at the moment. If shared targets between countries are not allowed or is complicated, the question whether harmonisation is needed in not relevant at this stage. If the Commission requirements set no limitation, the next question is whether a common political will for harmonisation can be found within Nordic countries in the given time frame or is a longer frame and also a larger EU-wide scope more relevant for harmonisation. 


\section{Introduction}

The EU Commission published a far reaching Climate action and renewable energy package on 23 January 23 2008. The package sets out the contribution expected from each Member State in meeting the EU targets of reducing emissions by $20 \%$ from 1990 levels by 2020 and increasing the share of renewable energy in energy use up to $20 \%$ by 2020 . Moreover, the package proposes a series of measures to targets are to be achieved. The main items proposed in the package include:

- Review of the EU Emissions Trading Scheme (EU ETS): introduction of EU-wide emission cap and harmonised allocation across the EU with full auctioning to energy sector, inclusion of new sectors and gases and possibility to exclude small installations.

- Country specific targets for share of renewable energy by 2020 with possibility to trade with Guarantee of Origin (GoO) between countries.

- Country specific emission reduction targets for the non-EU ETS sectors.

The EU ETS and trading with GoO are already taking place - some 1500 Mt of emissions allowances were traded and almost 100 TWh of GoO were voluntary used in the market in 2007. Still, to achieve the ambitious targets for renewable energy and greenhouse gas emission reductions, effective policies and measures has to be implemented. In addition, possibilities need to be considered over traditional and conservative solutions.

One possibility for such solution could be the harmonisation of renewable energy support mechanisms over countries. For Nordic countries this option is seen especially promising due to the long co-operation on energy issues. Harmonisation of the schemes for promoting the use of renewable energy sources (RES) has been on the agenda and it has been estimated that harmonisation can improve market conditions for trading with renewable electricity and efficiency of the markets. However, the consequences of harmonisation on security of supply, energy prices, promotion of less mature technologies and employment are not trivial and any informed decision on harmonisation measures require analysis of those impacts.

The overall objective of this report is to contribute and provide recommendations for the decision making process concerning possible introduction of harmonised or common Nordic RES support instruments and framework for promoting renewable energy sources. The main objective of this report is to: 
- Identify and evaluate the main support instruments and their characteristic from the harmonization perspective

- Evaluation of the potential and costs for increasing RES in Nordic countries

- Evaluate usefulness, consequences and benefits of the harmonisation

- Evaluate in what extent harmonization could be implemented and what are the prerequisites for harmonization

- Provide recommendations 


\section{Methodology}

This report aims at exploring the possibilities of implementing harmonised renewable support scheme in the Nordic countries. The project will also consider how a possible harmonisation would affect the demand on labour, security of supply and energy prices in these countries. The analysis will concentrate on the impacts that can be derived from the anticipated increase of the selected important renewable energy applications (hydropower, biomass and wind power).

The analysis will take into account the impacts in the areas where there are clear results from implementing the scheme such as labour required for building, operating, and maintenance as well as fuel supply of the most important renewable energy applications. Potential impacts in the following areas will be excluded from the analysis

- Impacts in the research and development of technology providers

- Any impact which is not directly related to building or operating the selected important applications of renewable energy (for example possible impacts in pulp and paper industry due to energy use of biomass are not analysed)

The analysis will be based on different data sources where some of the most important would be the data on each countries target for use of renewable energy sources, data on renewable increase potential and previous studies on benefits and impacts of harmonisation.

The renewable energy targets for Denmark, Finland and Sweden are set out in the European Commission's (EC) proposal and the targets are further converted to quantified increase targets. For Norway a similar target will be designed ${ }^{1}$. Data on the renewable energy increase potential for each country will be based on the EC`s proposal and other relevant papers where governmental studies will be preferred sources.

There have been several extensive studies on possible harmonisation of support systems for renewable energy in Europe and the Nordic countries. The results and recommendations are utilised in this study.

\section{Interviews}

Within the study, 32 stakeholders in Nordic countries were contacted and 21 eventually interviewed. They represent large and small energy producers, interest groups as well as administration in each Nordic country.

\footnotetext{
${ }^{1}$ Iceland is excluded from the harmonisation analysis but is discussed separately in Annex 2.
} 
The interviewed stakeholders were asked view on renewable energy support instruments in general, what is their opinion on harmonisation and what instrument they favour. These dialogues provide further background on the policy making as well as opinions of major actors that shape Nordic energy policy. The framework for questions, list of interviewed stakeholders and a summary result can be found in Annex 8-10.

\section{Methodology for optimisation}

The possible impacts harmonisation will have are analysed based on a quadratic optimisation model that was built within the study. The goal of the optimisation is to minimise the cost for the renewable electricity production mixture in the Nordic countries in 2020. Hence a dynamic model for time steps and for intermediate RES targets is not created. Decision variable in the model is production $Q$, over a range of different technologies in each Nordic country.

Cost for each technology is calculated by multiplying the price of production with the production level. The price $P$ is presented as a function $P=a+b^{*} Q$, where " $a$ " and " $b$ " are constant values, and $Q$ is the production volume in TWh. The total cost is defined as the sum of all technologies and countries as $P^{*} Q$. Hence is the cost function a quadratic function, for which an optimum is guaranteed.

The optimisation is done with a constraint that the total renewable target for each country must be reached but the production of each technology cannot exceed the estimated potential available in each country. For example: production $Q$, for onshore wind energy in Denmark, cannot exceed 2.76 TWh which is estimated to be the maximum potential in Denmark.

Based on the results driven from the optimisation model the status and position of each Nordic country under a non-harmonised and under a harmonised market solution is analysed. In addition, a segmented market solution - that is we assume that the harmonised market solution brings a certain amount of the selected technologies to the markets - is analysed. Finally, this analysis gives the basis for estimation of the possible impacts harmonisation will have on labour, security of supply and energy prices. The views and opinions of interviewed stakeholders is also utilised at this point. 


\section{The european commissions work on RES}

\subsection{Background}

On January $23^{\text {rd }} 2008$, the European Commission put forward a proposal for a new directive in order to reach the long-term targets set by the European Council and European parliament. This far reaching Climate action and renewable energy package sets out the following contribution expected from each Member State in meeting the EU targets by year 2020 to mitigate the climate change:

- Reduce greenhouse gas emissions by 20\% from 1990 levels

- Increase the share of renewable in energy consumption to $20 \%$

- Increase energy efficiency by $20 \%$

The European Union work for climate change mitigation and promoting renewable energy includes following, previous milestones:

- 1997: Commission White Paper on 'Energy for the future: renewable sources of energy - White Paper for a Community Strategy and Action Plan', sets an EU target for increasing the share of renewable energy to $12 \%$ from total energy consumption by 2010 .

- 2001: The European Union adopts the Directive on the Promotion of Electricity produced from Renewable Energy Sources ('Renewables or 'RES-E Directive'). The directive sets an EU-wide target of $21 \%$ of renewables share in electricity consumption by 2010 .

- 2003: EU adopts the Bio fuel Directive setting "reference values" of 2 \% market share for bio fuels in 2005 and a $5.75 \%$ share in 2010.

- 2006: European Parliament calls for $25 \%$ target for renewables in EU's energy consumption by 2020.

- 2007: Commission presents "Renewable Energy Roadmap" as a part of its "energy-climate change" package.

- 2008: The Proposal for a directive of the European Parliament and of the council on the promotion of the use of energy from renewable sources. 


\subsection{The Energy and Climate Package}

The new climate package from the European Commission proposes a number of measures how the targets are to be achieved. The main items proposed in the package include:

- Review of the EU Emissions Trading Scheme: introduction of EUwide emission cap and harmonized allocation across the EU with full auctioning to energy sector, inclusion of new sectors and gases and possibility to exclude small installations.

- Country specific targets for share of renewable energy by 2020 with possibility to trade with Guarantee of Origins between countries.

- Country specific emission reduction targets for the non-EU ETS sectors

The proposal says that the Member States should increase their share of renewable energy as an effort to boost the EU's share from today's $8.5 \%$ up to $20 \%$ by 2020 . Table 1 presents the RES increase targets for each Member State. A $10 \%$ increase in the share of renewables in the transport fuel consumption is included within the overall EU objective.

To achieve the common target, every nation in the 27 -member bloc is required to increase their share of renewables by $5.5 \%$ from 2005 levels, with the remaining increase calculated on the basis of per capita gross domestic product (GDP). 
Table 1 Targets for share of renewable energy in EU countries by 2020

\begin{tabular}{|l|c|c|}
\hline \multicolumn{1}{|c|}{ Member State } & Share of renewables in 2005 & Share required by 2020 \\
\hline Austria & $23.3 \%$ & $34 \%$ \\
\hline Belgium & $2.2 \%$ & $13 \%$ \\
\hline Bulgaria & $9.4 \%$ & $16 \%$ \\
\hline Cyprus & $2.9 \%$ & $13 \%$ \\
\hline Czech Republic & $6.1 \%$ & $13 \%$ \\
\hline Denmark & $17 \%$ & $30 \%$ \\
\hline Estonia & $18 \%$ & $25 \%$ \\
\hline Finland & $28.5 \%$ & $38 \%$ \\
\hline France & $10.3 \%$ & $23 \%$ \\
\hline Germany & $5.8 \%$ & $18 \%$ \\
\hline Greece & $6.9 \%$ & $18 \%$ \\
\hline Hungary & $4.3 \%$ & $13 \%$ \\
\hline Ireland & $3.1 \%$ & $16 \%$ \\
\hline Italy & $5.2 \%$ & $17 \%$ \\
\hline Latvia & $34.9 \%$ & $42 \%$ \\
\hline Lithuania & $15 \%$ & $23 \%$ \\
\hline Luxembourg & $0.9 \%$ & $11 \%$ \\
\hline Malta & $0 \%$ & $10 \%$ \\
\hline The Netherlands & $2.4 \%$ & $14 \%$ \\
\hline Poland & $7.2 \%$ & $15 \%$ \\
\hline Portugal & $20.5 \%$ & $31 \%$ \\
\hline Romania & $17.8 \%$ & $24 \%$ \\
\hline Slovak Republic & $6.7 \%$ & $14 \%$ \\
\hline Slovenia & $16 \%$ & $25 \%$ \\
\hline Spain & $8.7 \%$ & $49 \%$ \\
\hline Sweden & $39.8 \%$ & \\
\hline United Kingdom & $1.3 \%$ & $\%$ \\
\hline & & \\
\hline
\end{tabular}

The Commission also proposes a series of interim targets (indicative trajectory), in order to ensure a steady progress towards the 2020 targets.

- 25\% average between 2011 and 2012;

- 35\% average between 2013 and 2014;

- 45\% average between 2015 and 2016, and;

- 65\% average between 2017 and 2018.

The EU Member States are free to decide their preferred mix of renewables in order to take account of their different potentials, but they must present national action plans outlining their strategies to the Commission by 31 March 2010. The plans will need to be defined along three sectors: electricity, heating and cooling and transport.

While only the 2020 target is legally binding, the Commission has indicated that it could pursue earlier legal action in cases where a Member State's progress is so limited that it is clear the final target cannot be reached. 
In Figure 1 the share of renewable electricity (RES-E) in the EU 25 countries by 2006 compared to 2010 targets is presented. The figure shows that there is a large gap between the target and the actual share, which could illustrate how ambitious the EC`s 2020 goals are. This also implies that there is a strong need for effective and efficient support systems if the 2020 goals are going to be met.

Share of renewable electricity (\%)

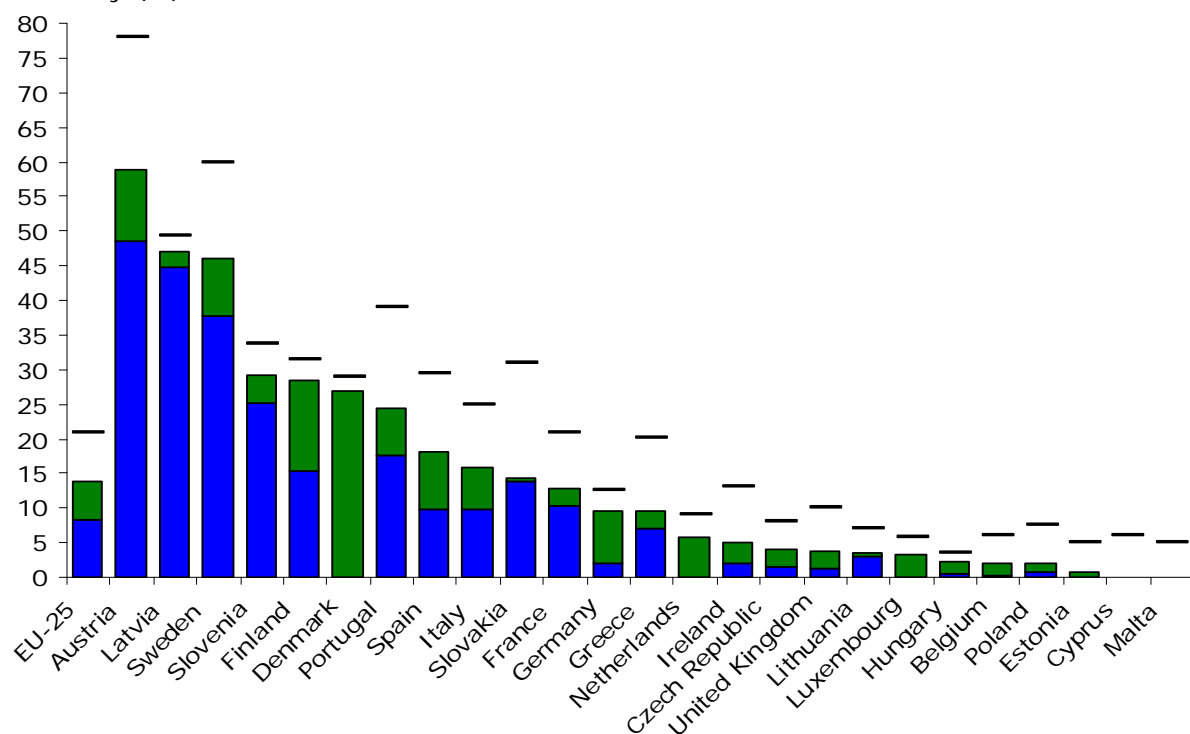

\subsection{Using Guarantee of Origin trading to meet targets}

The Commission's proposal allows for the virtual trade in renewable energies involving Guarantees of Origin, which certify the renewable origin of electricity produced and is seeking to improve cost-efficiency. This provision already features in the existing EU renewable legislation, but has hardly been utilized, according to the Commission.

Under the system, the Member States may invest in renewable energy production in another Member State in exchange for GoOs, which can then be counted towards the renewable target. But the Commission has attached the condition that a Member State must have already reached its own interim target before being allowed to receive investments and transfer GoOs to another Member State. In addition to Member State level trading, also private operators e.g. energy companies could trade with GoOs as well. The Commission's proposal includes possibility for Member States to restrict or prohibit transfer of GoOs if such transfer would 
undermine the secure and balanced energy supply, the environmental objectives of the domestic support schemes or would jeopardize the achievement of the indicative trajectory.

The possibility to trade with the GoOs has raised many questions and the proposal is not very clear on $\mathrm{GoO}$ trading. In general, international trading with GoOs is allowed but the details are still vague. The directive negotiations are ongoing and the final outcome of the GoO provisions of the new RES directive are in key role in determining weather a harmonised common renewable energy subsidy system covering several countries is possible.

\subsection{Harmonisation of support instruments}

In December 2005 the EC reported in a Communication to the Council and Parliament on the support of renewable energy sources in the EU 25 Member States. The EC analysed the different existing support systems and their success in increasing the share of renewable electricity. The results that were presented in the Communication paper were based on various studies. In addition to Member State and Commission experiences, extensive work was conducted by research institutions from several EU countries and extensive stakeholder consultations were conducted.

The report of the EC explained how the different support systems perform based on economic indicators. It discussed and identified the possible barriers for better development in renewable energy and gave some recommendations for further development and harmonisation. Based on the analysis of the performance of different support systems the EC called on the Member States to continue to harmonise and co-ordinate their support systems. The Commission considers a co-ordinated approach on support schemes on renewable energy sources as appropriate, based on two pillars: co-operation between countries and consideration for optimising the impact of the national schemes.

By and large, based on initial reactions of the Member States, the Commission proposal for Climate and energy package published on January $23^{\text {rd }} 2008$ has gained support at least the main content of it. One of the questions under discussion has been the, some may say controversial distribution of targets between the emission reductions and renewable energy increase. Several stakeholders highlight the importance to build the targets on the emission reduction goals rather that renewable energy. The RES directive is due to be presented in the European Parliament on June 26th 2008 and it has been debated earlier in 2008 in the EU Council.

From the Nordic RES support harmonisation point of view the biggest challenge in the Package is that it does not make easy to implement a common support system as the targets are set for the Member States and 
trading with GoOs are not a straight forward. This question also shadows the research made for this report as a shared target would be the only sensible bases for a common support scheme. This was also noticed among the stakeholders interviewed within this study. A common comment for harmonisation was that is an important issue and would bring added value but under current circumstances it is not an issue. 


\section{Evaluation of the policy instruments}

This chapter presets the main support policy instruments for renewable energy, concentrating on electricity production. Special emphasis is placed on tradable green certificates, fixed feed-in-tariffs as well as on premium feed-in-tariffs since they are considered to be the most potential choices for possible harmonisation in the Nordic Countries. The objective of the analysis is to identify and evaluate the characters that determine each instrument's suitability for harmonisation.

\subsection{Tradable green certificates}

\subsubsection{Basic principle}

The basic principle of a green certificate system is to separate the actually produced electricity from its environmental value by selling the produced electricity in electricity markets as usual and the environmental value as a separate product to the green certificate markets. The amount of produced tradable green certificates equals to the amount of electricity produced on renewable source of energy; usually one certificate corresponds to one megawatt hour (MWh). The demand of certificates consists on buying obligation placed on certain party of the electricity markets. The obligation is defined as a percentual share of produced, sold or off burned electricity and the obligated party must annually deliver a corresponding amount of certificates to the monitoring authority. The producer of renewable electricity and green certificates receives profits on selling the certificates which again motivates to increase the renewable energy production.

Green certificate system is a market based instrument where the buyers' objective is to fulfil the imposed obligation with least cost and the seller faces competitive markets for supplied certificates. This promotes to increase the use of renewable energy where it is done in the most cost efficient way.

\subsubsection{Status in the Nordic countries}

From the Nordic countries, a tradable green certificate system is currently in place in Sweden. The Swedish scheme was launched in 2003 and its goal is to increase the share of renewable electricity by 17 TWh from the 
2002 level by 2016. The scheme is planned to continue until 2030. Norway was rather close of joining the Swedish system in 2007. The political atmosphere towards green certificates however changed in early 2006 and the connection of the Norwegian installations to the system was postponed. After a few months of negotiations it was finally decided that there will not be a joint Swedish-Norwegian market for green certificates. For Norway, one of the presumed reasons for the rejection was the estimated costs for consumers whereas Sweden was not pleased with the possible placing of new investments. However, discussions on a joint scheme are rising again.

Tradable green certificates have also been a subject of discussions in Danish energy policy during the past ten years. The general atmosphere has changed from favouring to rejection and back to positive. The declining stand was supported by the doubt that the scheme could not provide sufficient support for renewable energy forms. Neither Finland nor Iceland has previous history with domestic tradable green certificates.

In addition to Sweden, from European countries e.g. UK has launched a scheme for tradable green certificates. In following, experiences from both Sweden's and UK's systems are exploited.

\subsubsection{Implementation in practice}

The purchase obligation for green certificates is usually defined for several years' advantage. Typically the obligation is a fixed percentage share of total electricity consumption in each year. UK has complemented the system by adding a "guaranteed shortfall" rule meaning that the purchase obligation will be increased in the following year if the annual target is reached or is very close to be reached in next year. However, the rule includes also a maximum obligation (percent from total consumption) which the obligation level cannot exceed. This heads to decrease the risk of oversupply of certificates that might cause the certificate price to collapse in the future.

The obligation is usually placed on electricity supplier since it is more convenient for an electricity supplier to operate in a certificate system than a single consumer. In the Swedish system however, the obligation is, in principle, placed for a consumer but in reality the actual operation is at least in a case of a smaller consumer - entrusted for electricity supplier. Thus this arrangement enables for a consumer the opportunity to look out for its own obligation.

In addition to the level of obligation, an important question for practical implementation is defining which energy sources, technologies and plants are included in the system. In a typical case, the system covers all renewable energy including wind, biomass, bio gas; certain scale hydro power as well as developing technologies like solar, tidal and wave energy. The eligibility of certain technology can be limited if there is a risk 
that the inclusion would have a significant negative impact in the stability of the system. For example, in the UK- scheme the co-combustion of biomass with coal is limited to $10 \%$ in order to prevent such production to increase massively in a short run which again could have a negative impact on the certificate system and could decrease new investments.

The lifetime and eligibility of certificates are also essential issues to determine. Certificates are usually delivered on a monthly basis and returned to authority in a yearly basis based on the obligation. Banking unused certificates for following year is in most cases allowed which reduces the possible effect yearly changes in renewable electricity production may have on certificate price.

\subsubsection{Costs}

In theory, the price for a certificate is determined as the difference between electricity market price and production costs of renewable electricity. Ultimately this difference falls for electricity end users expense irrespective of to whom the obligation was originally placed. Following this, the theoretical income distribution in a certificate based system is from the consumer to the producer. In reality, some shares of this income are likely to end up for other parties involved in the value chain since the system is market based. For example electricity companies facing the obligation can hold a share of the profit as a compensation of caused transaction costs or risk burden. In the context of this study, it is important to highlight the fact that in competitive markets the certificate price is determined by the marginal costs of renewable electricity production. Following this, renewable electricity producers with lowest production costs benefit the most from the system. Again, this is in line with system's the cost-efficiency principle. There again, it is possible to differentiate the support levels for different technologies and thus guarantee support also for more expensive renewable technologies.

The administration of a certificate system requires relatively heavy planning, monitoring and follow-up compared to some other support instruments. In addition, it requires the establishment of specific register for certificates. Costs occur also from the plant registration, reporting, trading and verification. The role of administration in this process is significant. Inadequate and unclear rules will increase the system transaction costs for all parties and this will undoubtedly be emphasised if several countries are involved in the system.

\subsubsection{Efficiency}

Cost-efficiency and dynamic efficiency are considered to be the focal strengths of tradable green certificates. A well functioning system directs new investments always to the lowest cost production technologies. In the 
UK, the system has - at least partially - given signals to this effect; the share of mature and affordable technologies such as biomass, biogas and onshore wind has increased notably. Instead, offshore wind and some developing technologies like solar and tidal energy have not increased their share even though they are considered to have a focal position in reaching UK's future targets. Following this, these production technologies are additionally supported by investment subsides and loans.

There again, the cost-efficiency of certificate systems is often criticized because they do not take into consideration different production costs but the certificate price is the same for all producers. Following this, some producers with lower production costs receive a bigger producer surplus than others. At this point, certificate systems are often compared to feed-in-tariffs, where the prices are said to reflect merely the production costs. For these two reasons - to promote new technologies and to lower producer surplus - UK is planning to relinquish the cost-efficiency advantage of its certificate scheme and divide different production forms based on their costs into separate categories which would then be delivered a differing amount of certificates based on their production costs. This would differentiate the production forms likewise in the German feed-in-tariff system but the price would still be determined marketbased. In general, separated support levels are a common feature that can be adapted in nearly all policy instruments.

Efficiently functioning certificate system requires also liquid markets. The size of currently existing schemes is considered to be effective but still there are challenges for liquidity. For example in the UK, the demand side is dominated by 5 to 6 big electricity companies meaning that the market is practically oligopolistic (Toke, 2006). A prominent point for certificate markets is long run price signals. The UK system has been unable to create liquid derivative markets that could provide some hedge even for medium term. So far the only option is to agree long, bilateral contracts without any public price reference. Long run uncertainty is often seen to abate the cost-efficiency of certificate system. In the UK, this problem is answered by extending the obligation periods and by this earlier described "guaranteed surplus" tool. Also the early steps of the Swedish system suffered from the lack of long run credibility and reliability. However, at the moment it considered to "be giving results according to expectations" as one stakeholder put it. Still, the system is considered to be too small and it is criticised to favour producers.

Overall, the number one reason for favouring a certificate system among the interviewed stakeholders was its efficient, market based nature. Even those who favoured other mechanisms did not deny that green certificate system would lead to most cost-efficient solution -at least when looking at economical indicators.

In general, the dynamic efficiency of certificate systems is considered to be good. In theory, certificate prices should reflect the changes in re- 
newable energy production costs since the level of needed support fluctuates along with electricity market price. Dynamic efficiency should, in addition, encourage to constant cost lowering.

\subsubsection{Impact on investments}

In principle, a support system based on tradable certificates suits the best for large companies who can utilise their large balance sheet in project financing. For small scale project development the system can be challenging since new investments require long time scale but no equally long scale price signals for certificates exist. This makes project financing more complicated for small scale projects and often bilateral contract between project developer and the possible certificate buyer is required to secure the profitability of the project. A bilateral contract transfers a share of the project risk to the buyer, who partly guarantees investment's creditworthiness by underwriting a long delivery contract. In exchange of the risk sharing, the project developer must pass on a share of certificates' value to the buyer. Bilateral contracts do however not guarantee investment requirements for every case since purchase contracts are often much shorter - around 5 to 10 years - compared to the investment lifetime (ECN, 2005).

The Swedish system has increased investments in renewable energy, so far most significantly in bio fuel-based electricity production. Instead, investments in wind power have grown much slower. This is however a natural character for the system: it aims constantly to bring the cheapest available technology to the market which reflects the cost-efficiency of the instrument. In Sweden, bio fuel-based electricity was the cheapest technology available as the system started and it was first brought to the market. The next "big" technology entering the market is expected to be wind power. This is also acknowledged and accepted among the Swedish stakeholders interviewed within this study. However, the interviewees placed their concern that the system does not promote research and development to new, developing but more expensive technologies, and thus does not drive technology development enough. In the UK, the share of renewable in electricity production has increased faster since the certificate system was introduced in 2002 (DTI, 2007).

\subsubsection{Impact on electricity market and prices}

The impact of a green certificate scheme on electricity market and power prices is very dependent on how the scheme is set up. Whether the system is technology neutral or some technology specific rules and/or limitations is designed into the system. As discussed above in the section of implementation, different setups can lead to disturbance in prices, and evoke less investment in renewable energy production as planned. 
Even though favouritism or restricting of certain technology might reduce confidence to a green certificate system, limiting the contribution of certain technology can in some cases be justified. Implementation of such measures might arise in order to avoid possible over supply from certain technology and to ensure security of supply. Excessive supply of power/energy from a technology will for sure undermine a green certificate system, and hence bring green certificate prices towards zero after a while. An oversupply in the market will lead to lower electricity prices and thus lead to transfer of wealth from the owner of production facilities to consumers. Unwanted effects of low prices are often under investment in maintaining the existing production capacity and increasing energy consumption.

An important factor in determining the price effects of a certificate scheme is the ultimate target set for the scheme; how much are purchasers obliged to buy certificates. Hence is an evaluation of volume and price together a necessity ${ }^{2}$.

A green certificate scheme can be viewed as a subsidising scheme when considering price effects, and will - under given circumstances lead to lower prices. Support schemes like green certificates introduce extra production into market that is already fully supplied. As the supply in the markets increase, the price decreases.

However, under an ambitious scheme where the buying obligation is set very high, the effect can be adverse compared to previous. In the beginning of the scheme, electricity price will fall but as mandatory buying obligations are increased over time the certificate price will increase. Under these conditions, the electricity price will end up being higher than what it was before the certificate scheme was introduced.

A green certificate system is a market based solution thus uncertainty in the level of support is larger than for other support schemes. Still, a market based system provides cost minimisation. However a poorly constructed green certificate system might yield opposite results, and sometimes even lead to abuse of it.

\subsubsection{Suitability with other policies}

In principle, a tradable green certificate system is compatible with other policy instruments due to its good dynamic efficiency. This is an important matter when considering the interaction with the current EU Emissions Trading Scheme. A green certificate system is able to react to price changes in emission markets; as the increasing allowance price (and related long term expectations) increases the electricity price, several renewable energy investments become profitable. Increases in renewable electricity capacity, as well as in production are considered to have a focal impact on the certificate price in the UK. It decreases the certificate

\footnotetext{
${ }^{2}$ An example of such study is Bye, T. 2003, Discussion papers No. 351, On price and volume.
} 
market price and thus compensates the increase in emission and electricity prices. Single daily or monthly changes in the emission and/or electricity markets do however not affect the certificate markets as such, since changes in energy sector's investment require a long time scale. Following this, long time scale and sustainability in support policy are essential demands.

\subsubsection{Suitability for harmonisation}

Green certificates are generally thought to be the most promising instrument when considering harmonisation renewable energy support among several countries. During the past decade, politicians and scientists have discussed on the possibility to implement a harmonised EU-level scheme for green certificates. However, efficiently functioning scheme requires solid and competitive electricity markets - something that doesn't currently exist in the EU-level. The European Commission noted in the end of year 2005 that there is no need for harmonisation at this point and therefore an EU-wide harmonisation is not realistic in the near future.

The question of Nordic harmonisation is however current. As mentioned previously, a joint Swedish-Norwegian market for certificates was close to be implemented in 2006. Main arguments for international markets are the prospects for better functionality (due to larger market volume, turnover and liquidity) and the differences in renewable production potential. Studies ${ }^{3}$ related to the outcome of a common market basically come to the same conclusion that the certificate market would be highly dependent on the Norwegian quota.

To create a favourable climate for new renewable energy investments, one requires credible and persistent policy form the authority. This also culminates the biggest challenges of the existing Swedish and UK systems; that is to lack of persistency, continuity and price levels. This sets significant challenges also when considering green certificates in the context of Nordic harmonisation.

From the interviewed stakeholders Swedish and Norwegian respondents as well as Finnish respondents representing large utilities support a common Nordic certificate scheme. The main arguments for supporting a common market are that it is cost-efficient; it would provide large scale investments; it is non-discriminative and open system and a common certificate market would be in line with the Nordic electricity market. Stakeholders opposing a common market on the other hand argue that the system would favour large energy utilities that have the capacity and strength to take risks in the market but smaller players - who often pre-

\footnotetext{
${ }^{3}$ For example following studies have analysed the markets:

Profu, 2005. Analysis of a Swedish-Norwegian market for electricity certificates.

Profu, 2006. Extended model analysis of a Swedish-Norwegian market for electricity certifi-

ECON, 2004. Consequences of a certificate market in Norway.
} cates. 
sent new developing but more expensive technologies - do not have that option. Several respondents also raised the national perspective that a market solution would not deliver the benefits equally among countries.

\subsection{Feed-in-tariffs}

\subsubsection{Basic principle}

Fixed feed-in-tariffs

A fixed feed-in-tariff provides a certain minimum price for a unit of produced electricity that the electricity buyer is obligated to pay for a certain period of time. The price level is usually defined for certain technology but also more specific factors, such as size, location, technical specifications can be used. The goal of the system is to encourage new investments by providing a sufficient price level but also by providing it for a certain period of time -usually seven to twenty years - that decreases the risk level for new investments. A fixed feed-in-tariff system does not respond to the market price of electricity but it remains stable.

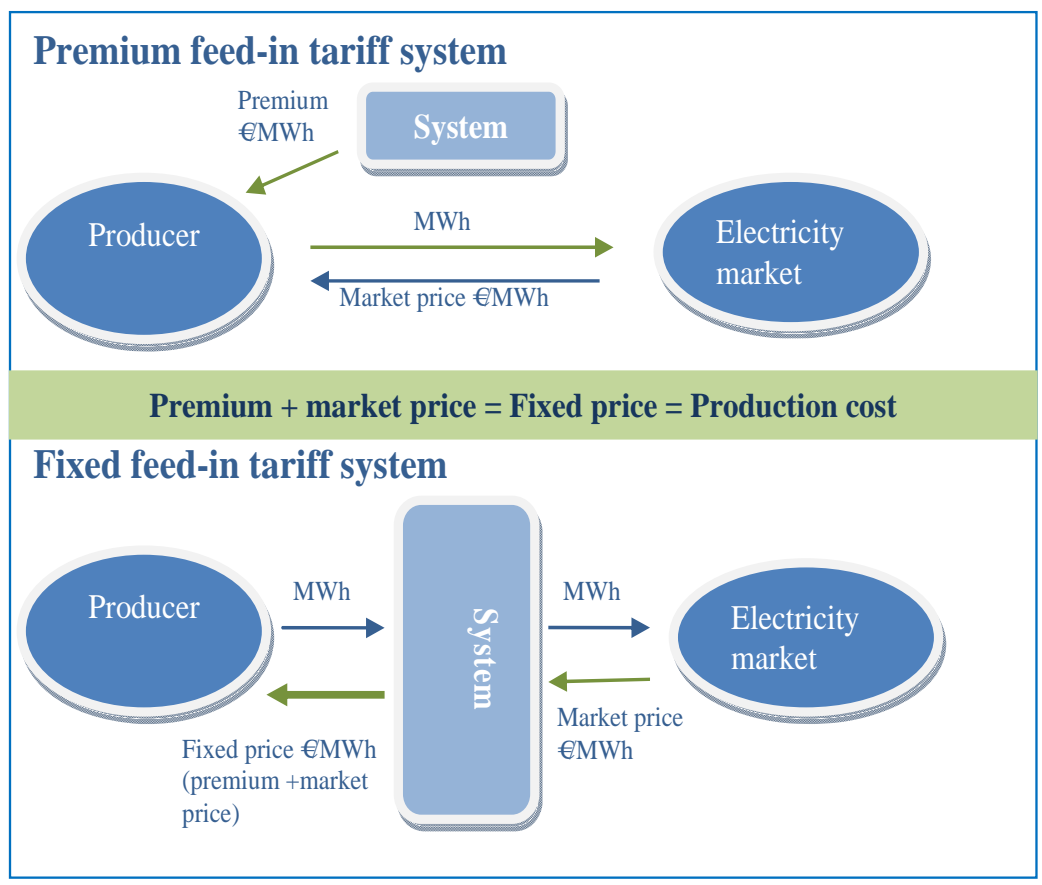

Figure 2 The principle of principle of fixed and premium feed-in-tariffs.

Premium feed-in-tariff

Under premium feed-in-tariff system the renewable energy producer receives a normal market price for electricity produced. In addition to elec- 
tricity market price, the difference between production cost and market price is paid to the producer as a compensation fee. Like a fixed feed-intariff, the system heads to encourage new investments but is more market oriented since the level of premium is dependent on the level of electricity market price. Figure 2 summarises the principles of fixed and premium feed-in-tariffs.

\subsubsection{Status in the Nordic countries}

From the Nordic countries Denmark has the longest experience on supporting renewable energy using feed-in-tariffs. The first scheme was introduced in 1993 and it placed a fixed price for wind-generated electricity. During the following decade, both wind and biogas energy were extensively supported through fixed tariffs which constituted significant amount new investments especially in wind electricity. In 2001 the system was revised and changed in to a premium based feed-in-tariff system. The support for windmills was notably lower compared to the fixed system and caused almost a complete stop in new investments. The support for biogas remained higher but still, the level has not been sufficient to stimulate the build out of new plants. (Tolonen J. et al, 2006.)

Currently no other Nordic country is using a feed-in-tariff system to support renewable energy production (except Finland is about to establish a scheme for biogas). In addition to Denmark also Germany and Spain have enforced feed-in-tariffs. In following, all these countries will be providing experiences.

\subsubsection{Implementation in practice}

Fixed feed-in-tariffs are typically defined for several years' advantage. The risk of implementing a policy regulation system is lowered by the fact that regulation will not change the price level for existing capacity but only for new built capacity. The basis for price level setting varies by system and by country. In Germany, for example, the level is defined separately for each production technology. Apart from few exceptions the support level remains the same through the system. In addition, the support level for new built capacity decreases each year by at least the level of inflation, meaning that new capacity introduced in 2006 receives higher support level throughout the system than new capacity introduced in 2007, etc.

Spain, on the contrary, has proportioned the price level into average electricity consumer prices. If electricity price increases also the price level for renewable electricity increases and vice versa. Also the German system offers some flexibility. New built onshore wind capacity is paid a fixed tariff for the first five to eight years; after that the installation receives proportioned tariff based on the installation's maximum utilisation 
time. This gives security for new investments loan instalment but it also increases the cost-efficiency of the system in the long run as profitable installations receive less support compared to new and less productive installations.

The biggest challenges of the system are related to the implementation phase when the level of tariff, time frame and other structural decisions are made. The resolution must be long lasting and give credibility to the system. The actual operation of the system requires very little administration.

\subsubsection{Costs}

Although the implementation of a feed-in tariff system is relatively straightforward and low cost compared to other mechanisms, can the possible overall costs of the system be considered as one of its weakest point. The previous Danish fixed tariff-system was a success if measuring the level of new investments but a main reason for abandonment were the rapidly increased system costs in the end of the last millennium. The costs were so high ( $€ 75$ million in 1998) that they severely threatened the overall cost-efficiency of the system. The current price premium based support system sets a ceiling for wind power total profits and even includes a repayment obligation in certain cases if the electricity market price exceeds this ceiling.

Experience the European countries point towards a higher cost for feed-in systems, than for green certificates. In Germany, a fixed feed-intariff system has increased consumers' electricity invoice by 7.2-8.2 $€ / M W h$. Certain energy intensive companies exposed to international competition face a lowered, $0.5 € / \mathrm{MWh}$ amount payment. The overall cost of the system is estimated to be around $€ 3.2$ to $€ 3.6$ billion which is the difference between the electricity market price and tariff fee. Around $8.5 \%$ of Germany's electricity consumption is under support system. In year 2006 they were paid total $€ 5.5$ billion which means that the average tariff level is around $104 € / \mathrm{MWh}$. Germany has an objective to increase the share of renewable energy in energy consumption up to $27 \%$ by 2020. This is estimated to increase electricity bills by $10 € / \mathrm{MWh}$. (BMU, 2006; BMU, 2007.) The target and the extent of the German scheme can be considered far reaching, and costs must be evaluated within that frame ${ }^{4}$.

The installations entitled to tariff must register to the system and make an agreement with the electricity distribution company. To local electricity resellers the system causes some administrative expenses related to reporting, invoicing and payments.

\footnotetext{
${ }^{4}$ Bye, T. (2003) Implies that the cost for the last production unit established is so high that the total cost the consumers face increase regardless of the subsidizing effect.
} 


\subsubsection{Efficiency}

With tariff based system it is possible to define exactly how cost-efficient or inefficient renewable energy is supported. For example in Germany, the average peak utilisation time in 2001-2004 was around 1500 hours/year when the similar figure in UK - who has had a market based support mechanism since 1990 - was around 2400 hours/year (Toke D. 2007.) Since then, the German system has been improved by decreasing the price level for onshore wind and respectively increasing for offshore. In addition, onshore wind has a base level for peak utilisation time which must be crossed in order to be entitled to support. Cost-efficiency can also be improved by tying the support level to the peak utilisation time for a certain time period.

An essential weakness on feed-in-tariffs is the lack of dynamic efficiency and possibly following lack of cost-efficiency. Even though it is possible to differentiate the tariff levels very specifically (assuming that the policy regulator knows the production cost of renewable energy), the systems usually reacts poorly to changes in external factors. Following this, it is very possible that the overall development leads to either over or under compensation for renewable energy. In the German model, the tariff level is fixed permanently while implementing new installations; if the level proves to be defective it is practically impossible to change it afterwards. Generally this is seen to decrease investment risks although dynamically efficient system would, in fact, minimise producer risk the best because the profit would react also in changes in cost level changes during an installation lifetime. This again decreases the volatility of investor profits. In theory, such flexible mechanisms could be built but in practice improving dynamic efficiency is mainly limited to proportioning tariffs based on peak utility time and on predefined decrease in tariff level. However, predefined decrease in tariff level is not a dynamic feature but merely predefined static development, which is not dependent on the true development of cost level and production profitability.

Finally, the problem of asymmetric information is also involved when measuring the efficiency. Policy regulator has more limited information on true production costs compared to markets which increases the risk of setting the tariff level inefficiently. In order to guarantee new investments the tariff is usually set too high.

\subsubsection{Impact on investment}

A fixed feed-in-tariff system removes all or nearly all market related risk from the producer of renewable electricity. Instead, the risk related to possible cost occurring from the system relies on the shoulder of the consumer; in case the electricity market price is lower than expected under fixed tariff the system is more expensive to the consumer than expected and vice versa. The low risk level producer faces has encouraged new 
investments that have lower profit requirements compared to situation under market based policy tools. This can be seen for example by comparing wind power investments in tariff based Germany into UK, where a certificate system is in use. A feed-in tariff has a special emphasis on production costs in capital intensive technologies in which most renewable energy technologies also include.

Tariff-based systems have also increased the amount of small, independent actors in the markets. Since adequate price is ensured for long period, the future cash-flow can be adequate secure for investors. This has encouraged local and small scale wind power for example in Germany and in Denmark. Currently $85 \%$ of onshore wind power capacity in Denmark is privately owned and vast majority of projects cover only one turbine.

This ability to instantly support all technologies was also acknowledged among the interviewed stakeholders. Practically all respondents even those who favoured certificate scheme - agreed that if feed-in tariff is set enough high it will no doubt evoke rapid new investments. However, this was also criticized by saying that investment decisions would not be cost efficient and may even lead to situation where technology require permanent support to be viable.

\subsubsection{Impact on electricity market and prices}

Fixed feed-in-tariff systems are generally criticised due to lack of compatibility with electricity markets especially in the long run. When the share of RES in the markets increases the cost-efficiency tends to decrease; costs increase and pricing contort competition. Even though electricity under a tariff system is separated to a distinct market it affects the competitive markets. Several RES production forms are investment intensive and the operation expenses are largely fixed. Variable costs instead are usually relatively low. As the share of this kind of "low-cost-mustrun" -production increases in the markets it starts to affect the merit order of production technologies. For example in Denmark and Germany wind power is detected to push production with higher variable cost out of the market and affect the electricity wholesale price (BMU, 2007). According to ECN (2005) tariff-based system suit best into situation where the starting level of RES in the markets is very low.

In principle, a feed-in tariff system has a similar effect on market price as a green certificate support scheme; more production enters the market and consequently the power price decreases. Still, even though the market price falls, production cost for this new generation capacity is higher than for the existing production capacity.

Feed-in support system can be designed in many different ways, and hence will impact from such scheme have equally many outcomes in price wise. Given the set of more or less mature technologies available for energy production, settling in to one common feed in tariff is not economically viable. Such support would lead to following. All production 
capacity with net present value above zero would be realised. This would lead to a rapid building of new production facilities and, assuming no limitation for any technology, this would mean a massive increase in construction of small scale hydro power and windmill farms. Under this situation the diversity of production technologies would not improve, hence the development of more sustainable technologies would suffer. Within the presented scheme the development of consumer prices is dependent on the level of support.

Concentration of production might also be an issue under such a solution, with very unstable prices in those areas containing production facilities built due to the scheme. As seen in Denmark, under extreme wind conditions prices fall close to zero and discussion about allowing prices below zero has been undertaken. Power prices close to zero comes as an result of over investment as guaranteed power prices from the feed-in tariff system remove this risk for the owner of the production facility.

On the other hand, if a feed-in tariff scheme supports multiple types of technologies, price effects will be more difficult to estimate. Average cost under such a scheme must necessary become higher than for a scheme that is technological neutral, since more less mature technologies must be supported. Increasing the diversity of renewable energy sources also increases stability in supply, and hence more predictability for prices.

\subsubsection{Suitability with other policies}

In principle, fixed tariffs can, as such, promote production for such technologies that are ready to commercialise but production costs are higher than market price. However it is worth noticing that both Germany and Spain have also other tools along with the tariff system. New technologies are usually promoted with direct investment supports, loans and R\&D supports.

A central issue related to suitability is how support policy for renewable energy functions with emission trading. Active use of renewable energy support mechanisms that has not been anticipated, including feedin-tariffs, may cause lower $\mathrm{CO}_{2}$ emissions than expected in emission trading sector and consequently decrease the price level in emission markets. On the other hand, if the tariff system has as good influence as expected (for example due to higher production costs than expected) it may cause emission market price level to increase higher than anticipated. When one counts the weak dynamic efficiency, it is possible that feed-in tariff systems increase long term uncertainty more than dynamically efficient instruments. On the other hand, tariffs suit with emission trading: if emission trading increases the electricity market price and the tariff level does not change, the additional fee consumers pay on renewable energy eventually decreases. 


\subsubsection{Suitability for harmonisation}

Feed-in-tariffs are generally thought to suite quite poorly for harmonisation due to their non dynamic nature. Moreover, agreeing the tariff level for different technologies would be extremely challenging since the production costs and conditions even for one technology vary significantly in the Nordic countries.

Within the interviewed stakeholders a harmonised feed-in tariff scheme was by definition not an option. Those who favoured feed-in tariffs supported national policy and argued also for national support schemes. The stakeholders were also asked whether it could be possible to have differing instruments but equalling support levels in Nordic countries. The general atmosphere among respondents was rather disbelieving towards such arrangement, it was stated to be too heavy to implement and it was difficult to see how countries could eventually benefit from the system.

\subsection{Other issues - Emissions trading and Guarantee of Origins}

\section{The EU Emissions Trading Scheme (EU ETS)}

The EU ETS will have a direct impact on power plants (some 11500) included in the scheme. In principle the main impact is due to increased costs of using fossil fuels. Competitiveness of the different power plants will change due to changed costs of different fuels and efficiency of the plants. This in fact is the basic idea of emissions trading - costs of using fossil fuels will increase compared to less carbon intensive fuels. Renewable energy sources do not have greenhouse gas emissions and consequently they will benefit from the rising costs of the use of fossil fuels.

By and large, emissions trading increase the price of electricity as the costs of the marginal power plant, typically condensing coal power plant, increases. The magnitude of the impact of emissions trading on the price of electricity depends on the price of emission allowances and the power plant park as well as the possibility of fossil fuel producers to transfer the allowance price to the electricity price. In countries where fossil fuel power plants are dominating, the price increase will be more significant. Estimates on the magnitude of the electricity price effect of emissions trading typically vary in the interval $0.2-0.8$ e.g. increase of $10 €$ in the price of emission allowances would increase the price of the electricity by 2-8 €/MWh.

From the renewable energy perspective the EU ETS can be seen beneficial as it improves their competitiveness but on the other hand in also brings a new variable in estimating the future energy market - price level of the emissions allowances and its direct and/or indirect effect to profitability of the renewable energy investments has to be estimated and taken into account in the investment decisions. 
The EU ETS is important driver for the renewable energy, but it does not make investments to the renewable energy profitable alone - additional subsidies are needed. Moreover, the EU has separate targets for the renewable energy and for the greenhouse gas emissions and it is difficult to meet both targets with one policy tool. However the both targets are interlinked and renewable energy subsidy systems will have an indirect impact the EU ETS market and vice versa.

\section{Guarantee of Origin}

The Renewable Energy Directive (2001/77/EC) requires that Member States implement a system of Guarantee of Origin (GoO) for electricity produced from renewable energy sources. The deadline for the implementation of the system was in October 2003 but many countries have not implemented the system yet.

The GoOs can be used for proving the origin of the sold electricity and one of the main purposes were $\mathrm{GoO}$ are currently used is to proof the part of the fuel mix in the electricity disclosure that is based on the renewable energy sources. Several Member States are using GoOs for disclosure purposes and other countries are recommending that GoOs would be used in the disclosure. In addition to disclosure, GoO's can be used in green electricity product sold to consumers. By using GoO's for green labelling it can be verified that the same production is sold only once and origin of the power is guaranteed.

The current operational $\mathrm{GoO}$ system can also be used for proving imports and exports or renewable energy and consequently it can be used for measuring how much renewable energy based power production was consumed in a specific country. In the EC's Communication ${ }^{5}$ (March 2004), the EC indicated that imports of RES-E can be used for reaching national RES-E targets. The perquisite for this is that the exporting country will deduct the exports from its national target counting. The GoO system could be used for monitoring and the trade but due to agreement between the countries there has not been any adjustment in the national RES-E accounting due to exports or imports.

The new energy and climate package (January $23^{\text {rd }} 2008$ ) is likely to modify the current $\mathrm{GoO}$ system with more importance given to the accounting the impact of the international trade of the GoO's to the RES targets. However the directive is still under negotiations and the outcome is unknown.

\subsection{Perspectives on harmonised support instruments}

While much of the debate on feed in versus cap and trade/ certificate systems poses them as polar opposites, we argue, from a dynamic per-

\footnotetext{
${ }^{5} \mathrm{COM}(2004) 366$ Final. The share of renewable energy in the EU.
} 
spective on support systems, that different instruments have their place in different phases of the product cycle. This perspective leads us to argue that feed in tariffs and certificate markets should not be seen as competing alternatives, but rather as complementary regulatory instruments targeting subsequent steps in the product cycle, on the way from early technology-conceptualisation and development towards competitive positioning in mature energy markets. We see both policy instruments as necessary to achieve the extensive transformation towards sustainable development that is judged as important tools in the context of the global climate challenge.

Viewing greening of the energy industry from a product cycle perspective implies a focus on continuous development of technological solutions from early stage experimentation to mature competitive products to drive technological learning curves (BCG 1968, Wene 1999). Society must therefore have at its disposal a spectrum of policy instruments adequately addressing the different stages of product development.

The stages of the product cycle should, in other words, be used for policy/regulatory design, where each stage requires distinct and highly different policy interventions, based on different mixes of dynamic innovation and static efficiency premises (Figure 2). In the early innovative phase of the product cycle, the focus of government regulation should be on dynamic innovation-oriented regulation including R\&D policies, technology subsidy policies and niche market policies. In the mature phase of the product cycle, relevant elements would be static efficiency-oriented regulation including competition policies, third party access policies and corporate governance policies.

Stimulus of early deployment, following the research and development phase, may probably best be supported by targeted measures such as feed in tariffs or specialised auctions. Such tariffs have the advantage of allowing differentiation and specific pricing of individual technologies, thereby permitting simultaneous development of a broad spectrum of technologies.

In later phases, where some technologies develop performance characteristics closer to established incumbent technology, niche markets, such as the certificate markets will probably provide a more adequate stimulus to further commercialisation before full competitiveness in the mainstream market is achieved. The new green technologies will then be exposed to general inter-technology competition and will have to win in this arena before being exposed to regular energy market competition in the next round.

The feed in tariffs and the certificate markets, thus, represent regulatory mechanisms adequately targeting different stages in the product cycle between early R\&D and later full market deployment. The feed in tariffs only exposes the technology to a benchmark cost model for the relevant technology, sometimes even favouring suboptimal conditions, by 
e.g. giving extra support for windmills in locations with poor wind. The certificate-market on the other hand exposes to cross-technology competition and gives no handicap-privilege.

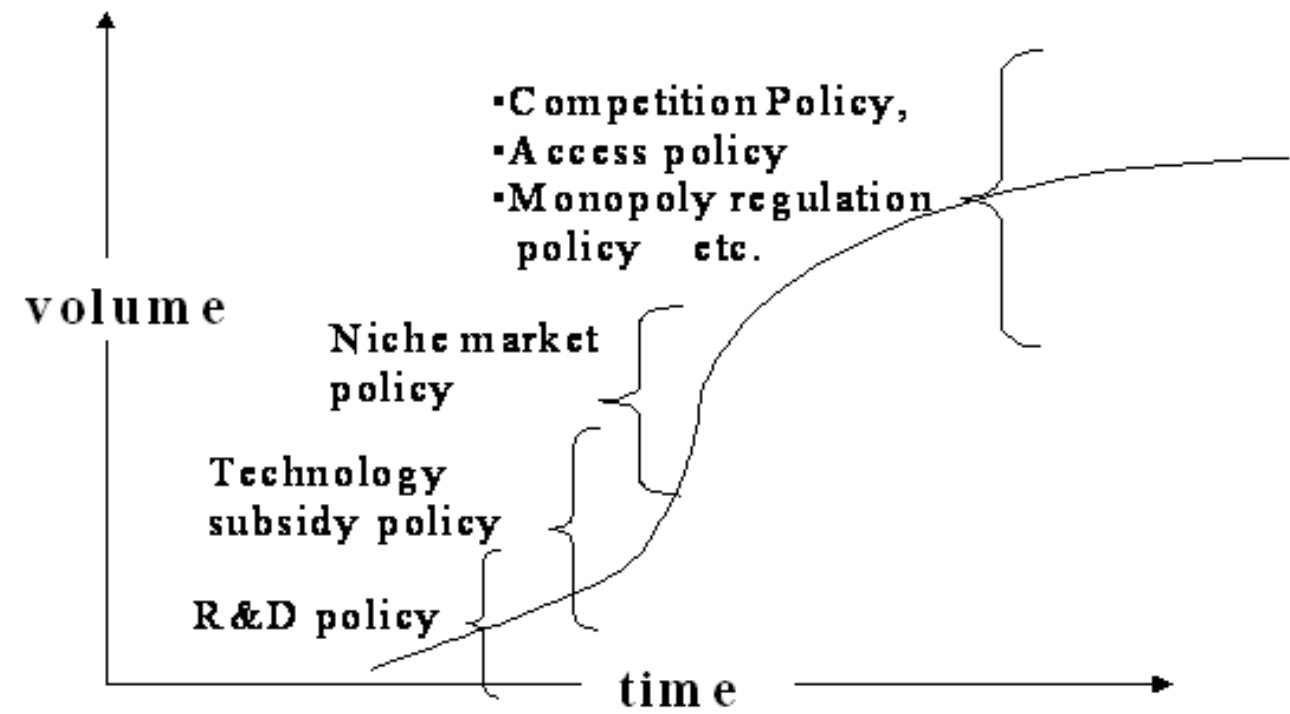

Figure 3 Policy instruments / regulatory approaches in various sections of the policy cycle.

However, the certificate system with free competition between all renewable technologies (except large hydropower) is clearly not capable of supporting the broader development necessary to further subsequent generations of renewable technology. It could, therefore, plausibly lead to a technological lock-in to mature renewable technology without stimulating future next generation technologies. This is an argument for also having supplementary feed in regulation at early stages of technological development.

Nevertheless, keeping technologies within a feed in mechanism for too long would probably slow down technology development as well as entail foregoing an efficiency potential. When technology development takes place under stronger competitive pressure, as in the certificate model, it would probably stimulate the development of new business models and increase the fit between technology and market needs, thus pressing technology development further down the learning curve.

Problematic from the competitive market point of view because the distribution company should be separated from electricity market. In the Nordic countries this does not sound fitted. In competitive markets you should be able to sell the electricity to whomever despite the location. A solution to this could be premium based tariff where the producer sells the electricity in competitive markets and the distribution company is obligated to pay the difference between the market price and tariff level. The payment would then be level 



\section{Renewable energy in the Nordic countries}

This chapter gives an overview on the status of renewable energy in Nordic countries and what are the proposed targets for 2020 by the EU Commission. Special emphasis in this Chapter is placed on analysing the possibilities each country has to increase the share of renewable electricity production by 2020. The potentials are estimated to be technoeconomically viable and realisable by 2020. Yet some restrictions do occur for individual technologies in some countries, these limitations are discussed more closely in context with the potentials. The potentials are only estimated for electricity production since a harmonised support system is most likely place on RES-E.

In order to evaluate the status of each Nordic country in a harmonised support scheme the production costs for each technology are estimated and a marginal cost curve for each country's production is created.

Within the interviews the stakeholders were asked, what is their opinion on the current RES policy in the country they are representing and what is their opinion on the RES-E potential. The opinions and comments are included within the chapter.

\subsection{Status of RES and targets for 2020 in the Nordic countries}

\subsubsection{The status of renewable energy support}

Denmark has had for decades a strong focus on supporting and promoting renewable energy, especially wind. Traditionally production has been supported by subsidies such as feed-in tariffs but lately the development is towards more market oriented mechanisms in order to increase the efficiency of the support systems. At the moment, subsidies are provided as follows: a specified feed-in tariff for plants utilising biomass, CHPplants burning waste and biogas and for wind turbines.

Interviewed Danish stakeholders recognised that in general, the support system has contrived a high share of RES for Denmark but the current level of support is generally seen too low - even though it has improved since February 2008. The biggest challenges are to create stabile conditions for investments which again require a longer time scope and 
on the other hand the system should be able to react into changes in economic situation and increasing costs.

In Finland renewable energy is supported as follows: production subsidies are provided for wind power, small-scale hydro, recycled fuels, forest processed chips and biogas. Previous tax benefit for electricity generated using wood and wood-based fuels, waste gas from metallurgical processes and chemical reaction heat was discontinued in early 2007 and all investment subsidies in the sectors under the EU Emissions Trading Scheme were suspended other than for innovative technology projects. Finland has a feed-in-tariff system to support peat in condensing power production and is planning to introduce a feed-in-tariff also for certain biogas plants.

Among the Finnish stakeholders the current support scheme is generally considered to work well (only one respondent criticized heavily the system) - good results have been accomplished with relatively low costs. However, it is also recognized that current support level is not adequate for the future targets and current tools would be too expensive. As one stakeholder put it "current support will not be enough, now is the time to go for it". Due to new targets the Finland is in a cross road with the RES support policy and new policy is expected soon.

In Norway the production is supported with production subsidies but is currently exploring other options. The Norwegian respondents expressed criticism towards the Norwegian support system by saying that it is too unpredictable and that the level of support is insufficient to evoke new investments.

Sweden has had a green certificate system since 2003 to promote the use renewable electricity. The set target for the scheme is to increase the share of RES-E by 17 TWh from the 2002 level by 2016 and the system is planned to continue until 2030. According to Swedish Energy Agency ${ }^{6}$, the share of RES-E in 2007 was 12.7 TWh and based on this, Sweden is on track meeting the target set for the scheme.

The Swedish respondents are pleased with the current system. They value that the system is market based, technology neutral and has encouraged first the cheapest investments into biomass and then promotes more expensive technologies such as wind. The disadvantages of the system are, according to respondents, that it does not give sufficient support for new developing technologies and the market is seen to be too small. One stakeholder compressed the experiences by saying that "the electricity certificate system seems to be giving results according to expectations".

\footnotetext{
${ }^{6}$ Swedish Energy Agency press release 17.4.2008. Available on line http://www.swedishenergyagency.se/
} 


\subsubsection{Renewable energy targets for 2020}

The European Commission proposes in its Climate and Energy Package ${ }^{7}$ binding renewable energy increase targets for Denmark, Finland and Sweden. As non members of the European Union neither Iceland nor Norway has such target but it is reasonable to assume that both countries will take some action or even comparable targets as the EU countries. Within this study, we assume that Norway will have a comparable increase target for RES. For Iceland such target is not defined as Iceland is not included on the harmonisation analysis in this study. This exclusion is made because of two reasons; first, including Iceland to a joint support scheme would require grid connections between countries and it is not likely that such capacity could be built by 2020. Secondly, the status of renewable energy in Iceland is very different compared to other Nordic countries, at this point RES production does not require support to be profitable. Following this, the term Nordic countries from this onwards refers to Denmark, Finland, Norway and Sweden.

The Commission proposes that Denmark should increase the share of renewables in energy consumption up to $30 \%$ by 2020 . In terawatt hours this requires an increase of $30 \mathrm{TWh}$ in yearly production. This is further shared between electricity, heat and cooling and transport sector. As this study concentrates on the possibilities for harmonised support system for electricity, the increase estimate for other energy sectors is not created. For renewable electricity production, it is estimated that in Denmark the production should increase by 18.4 TWh within the target. Comparable figures other Nordic countries -Commission targets and required increase estimate for electricity are presented in Table 2 . The estimates are based on Commission proposal, estimates presented by NEP Research Group (2008) and on GreenStream estimate.

Table 2 RES targets for 2020 and estimated share for RES-E in TWh.

\begin{tabular}{|c|c|c|c|}
\hline Country & $\begin{array}{l}\text { Commission proposal for } \\
2020 \text { target } \%\end{array}$ & $\begin{array}{l}2020 \text { increase } \\
\text { target in TWh }\end{array}$ & $\begin{array}{l}\text { Estimated increase target for } \\
\text { electricity production TWh }\end{array}$ \\
\hline Denmark & 30 & 30 & 18,4 \\
\hline Finland & 38 & 37 & 12,4 \\
\hline Norway & 66 & 37 & 10 \\
\hline Sweden & 49 & 55 & 22 \\
\hline
\end{tabular}

The current status of RES in each country is studied more closely in Annex 1.

\footnotetext{
${ }^{7}$ COM 2008, Proposal for a Directive of the European Parliament and of the council on the promotion of the use of energy from renewable sources. http://eur-lex.europa.eu/LexUriServ/LexUriServ.do?uri=COM:2008:0019:FIN:EN:PDF
} 


\subsection{RES-E increase potential and costs in the Nordic countries}

Based on the required increase estimates for RES-E made in previous chapter this section presents the potential each Nordic country has to increase the share on RES-E by 2020. In addition the costs that each country has for each technology are estimated. The costs are given as lowest and upper limit and the presented potential is estimated to realise in that range. Finally, a marginal cost curve for each Nordic country is created.

Following general assumptions are made for the cost calculations. Power price is estimated to be $45 € / \mathrm{MWh}$. The life time of new investment is 20 year and the inflation during installation life time is $2 \%$. More specific data on assumptions behind the cost calculations is presented in Annex 3. Table 3 The estimated potential increase for RES-E production and cost $€$ /MWh in Denmark.

\begin{tabular}{|l|c|c|c|c|c|}
\hline \multicolumn{7}{c|}{ DENMARK } \\
\hline \multicolumn{7}{|c|}{$\begin{array}{c}\text { Estimated increase } \\
\text { Technology }\end{array}$} & $\begin{array}{c}\text { Availability rate } \\
\text { potential by } 2020\end{array}$ & \multicolumn{2}{c|}{ Total price $€ /$ MWh } \\
\hline Onsore wind & 2,76 & 0,22 & 84,79 & 89,89 & OPTRES, 2006 \\
\hline Offshore wind & 9,38 & 0,34 & 73,2 & 81,48 & OPTRES, 2006 \\
\hline Biomass & 4,01 & 0,3 & 42,56 & 222,67 & OPTRES, 2006 \\
\hline Biogas & 1,65 & 0,3 & 77,95 & 237,86 & OPTRES, 2006 \\
\hline Bio waste & 0,3 & 0,3 & 196,29 & 264,45 & OPTRES, 2006 \\
\hline Photovoltic & 0,5 & 0,3 & 204,47 & 239,74 & OPTRES, 2006 \\
\hline Tidal and Wave & 0,1 & 0,25 & 119,53 & 150,68 & OPTRES, 2006 \\
\hline
\end{tabular}

As mentioned, Denmark has supported RES from the beginning of nineties and new capacity - especially wind power has been built increasingly. The fact that new capacity building is already rather developed affects especially the cost of new wind potential capacity increasingly since the most cost-efficient locations for wind mills are already in use and new capacity must be built in less favourable locations. Although the cost for wind electricity is increasing it is still the relatively cheapest technology for new RES-E capacity as shown in Table 3. Some biomass and biogas production is estimated to be available with even lower costs but in order to be able to utilise the whole potential the cost per MWh increases above 200€. The rest of the potential is estimated to come from tidal, wave and photovoltaic's that are all more developing technologies thus the costs are higher but also the realisation of the estimated potential includes some ambivalence.

The interviewed Danish stakeholders recognised that the presented Danish RES-E increase potential is realistic but also stated that it is likely - at least wind potential -to be more expensive compared to other Nordic countries. 
Table 4 presents the estimated renewable electricity increase potential and costs for Finland. Renewable energy potentials have been studied rather closely in Finland and the estimated potentials can be considered very realistic. As shown in the table, wood based fuels (alone 2,7 TWh) and wind power are expected to be the most potential sources for renewable energy along with recycled material and hydro power. The estimated potential do however include some restrictions: the share of forest based fuels in energy production can be significantly increased only by increasing the use of harvest woodchips and the utilisation of recycled material is highly dependent on the solutions made in general waste management. The estimated hydro potential again is partly located in protected areas, thus its utilisation would require inter alia changes in legislation. According to interviewed stakeholders the estimated potential is realistic and realisable.

Table 4 The estimated potential increase for RES-E production and cost $€ / M W h$ in Finland.

\begin{tabular}{|c|c|c|c|c|c|}
\hline \multicolumn{6}{|c|}{ FINLAND } \\
\hline \multirow[b]{2}{*}{ Technology } & \multirow{2}{*}{$\begin{array}{c}\text { Estimated increase } \\
\text { potential by } 2020\end{array}$} & \multirow{2}{*}{$\begin{array}{l}\text { Availability rate } \\
\text { for technology }\end{array}$} & \multicolumn{2}{|c|}{ Total price $€ / M W h$} & \multirow[b]{2}{*}{ Reference for potential } \\
\hline & & & low & high & \\
\hline Onsore wind & 1,83 & 0,3 & 62,08 & 65,82 & Pöyry Energy Oy, 2007a \\
\hline Offshore wind & 4,27 & 0,34 & 73,09 & 81,36 & Pöyry Energy Oy, 2007a \\
\hline $\begin{array}{l}\text { Forest biomass } \\
\text { and Straw }\end{array}$ & 3,6 & 0,3 & 43 & 78 & $\begin{array}{c}\text { Pöyry Energy Oy, 2007b } \\
\text { and Asplund et al, } 2005\end{array}$ \\
\hline Reed canary gras & 0,6 & 0,3 & 103 & 137 & VTT. 2005 \\
\hline Biogas & 0,7 & 0,3 & 93,71 & 219,98 & Aalto et al, 2007 \\
\hline Bio waste & 1,3 & 0,3 & 191,18 & 257,55 & $\begin{array}{c}\text { Asplund et al, } 2005 \text { and } \\
\text { Rintala et al, } 2007 \\
\end{array}$ \\
\hline Photovoltic & 0,1 & 0,3 & 199,1 & 233,45 & Asplund et al, 2005 \\
\hline Hydro & 1,33 & 0,5 & 25,63 & 86,55 & $\begin{array}{c}\text { Finnish Energy Industries, } \\
2008 \\
\end{array}$ \\
\hline
\end{tabular}

In Finland, increasing the share of biomass and hydro power are the most affordable ways to increase the share of RES-E. The potential for forest and agricultural biomass can be utilised in existing plants thus no new investments in capacity is considered. Also wind capacity is available wit cost under 100€/MWh. Other technologies show a minor potential and also a wider cost range.

The Norwegian renewable potential is estimated to big large -atleast for hydro and wind - and it is also estimated to be available with realtive low costs. As shown in Table 5. all estimated potential is available under $190 € /$ TWh cost. In the biggest bulk of potential - that is onshore and offshore wind - the cost range is relatively small as the difference between cheapest and most expensive terawatt hour is less than $20 €$ and still over 100 TWh of capacity could be built. The grid and its ability to 
take wind power is however limited which most likely causes limitations to the presented wind potential.

In addition to more established technologies, Norway has a relatively big increase potential in more developing technologies. Especially the potentials for wave and osmotic ${ }^{8}$ power are estimated to be substantial. However, since the technologies are still in a developing stage, the final realisation is even more uncertain than for other technologies - especially when one considers the rather short time scope for required increase.

Table 5 The estimated potential increase for RES-E production and cost $€ / M W h$ in Norway.

\begin{tabular}{|c|c|c|c|c|c|}
\hline \multicolumn{6}{|c|}{ NORWAY } \\
\hline \multirow[b]{2}{*}{ Technology } & \multirow{2}{*}{$\begin{array}{c}\text { Estimated increase } \\
\text { potential by } 2020\end{array}$} & \multirow{2}{*}{$\begin{array}{l}\text { Availability rate } \\
\text { for technology }\end{array}$} & \multicolumn{2}{|c|}{ Total price $€ / \mathrm{MWh}$} & \multirow[b]{2}{*}{ Reference for potential } \\
\hline & & & low & high & \\
\hline Onsore wind & 52,56 & 0,3 & 62,18 & 71,48 & NVE, 2005b \\
\hline Offshore wind & 59,57 & 0,34 & 73,2 & 81,48 & NVE, 2008 \\
\hline General biomass & 0,5 & 0,3 & 41,59 & 108,1 & NVE, 2004b \\
\hline Small hydro & 18 & 0,4 & 34,61 & 69,41 & $\begin{array}{c}\text { NVE, 2004a and } \\
\text { GreenStream estimate }\end{array}$ \\
\hline Large hydro & 3 & 0,5 & 30,85 & 88,1 & $\begin{array}{c}\text { NVE, 2005a and } \\
\text { GreenStream estimate }\end{array}$ \\
\hline Tidal & 1 & 0,25 & 139,3 & 139,3 & $\begin{array}{c}\text { Sweko Groner for ENOVA } \\
\text { SF, } 2007\end{array}$ \\
\hline Wave & 12 & 0,2 & 189,46 & 189,46 & $\begin{array}{c}\text { Sweko Groner for ENOVA } \\
\text { SF, } 2007 \\
\end{array}$ \\
\hline Osmotic & 12 & 0,79 & 87,38 & 94,39 & Statkraft, 2006 \\
\hline
\end{tabular}

The Swedish potential for RES-E increase is shown in Table 6. The biggest potential is expected to come from both onshore and offshore wind power. The presented potential can be considered as rather ambitious in the given time. Also the utilisation of biomass potential (forest and agricultural biomass) has limitations due to restricted CHP capacity. Thus in the table the potential is divided in two; 9TWh could be utilised in existing plants but to be able to increase the share requires new capacity building. Around $60 \%$ of the Swedish biomass potential is forest biomass, rest is agricultural biomass, mainly reed canary grass but also straw. Burning biomass in existing plants is also -among hydro - the cheapest but if new capacity is required, the price will increase up to $153 € / T W h$. As in Norway also the Swedish wind potential is available with relative low total production cost.

\footnotetext{
${ }^{8}$ In osmotic power production the osmotic pressure difference between fresh water and sea water is utilised. In the process the sea water and the fresh water are separated by a membrane. The sea water then draws the fresh water through the membrane and thereby increasing the pressure on the sea water side. This pressure is then used to produce power. Statkraft is currently building a prototype osmotic power plant.
} 
Table 6 The estimated potential increase for RES-E production and cost $€ / M W h$ in Sweden.

\begin{tabular}{|c|c|c|c|c|c|}
\hline \multicolumn{6}{|c|}{ SWEDEN } \\
\hline \multirow[b]{2}{*}{ Technology } & \multirow{2}{*}{$\begin{array}{l}\text { Estimated increase } \\
\text { potential by } 2020\end{array}$} & \multirow{2}{*}{$\begin{array}{l}\text { Availability rate } \\
\text { for technology }\end{array}$} & \multicolumn{2}{|c|}{ Total price €/MWh } & \multirow[b]{2}{*}{ Reference for potential } \\
\hline & & & low & high & \\
\hline Onsore wind & 20 & 0,3 & 62,18 & 65,92 & \\
\hline Offshore wind & 10 & 0,34 & 73,2 & 81,48 & \\
\hline $\begin{array}{l}\text { Biomass reguires } \\
\text { new } \mathrm{CHP}\end{array}$ & 8,5 & 0,3 & 68,13 & 152,88 & $\begin{array}{l}\text { Profu, 2007, Commission on Oil } \\
\text { Independence, 2006, }\end{array}$ \\
\hline $\begin{array}{l}\text { Biomass utilised in } \\
\text { existing CHP }\end{array}$ & 9 & 0,3 & 43 & 137 & $\begin{array}{l}\text { Energimyndigheten, 2007, Svebio, } \\
2004 \text { and GreenStream estimate }\end{array}$ \\
\hline Small hydro & 2 & 0,4 & 33,78 & 55,74 & Energimyndigheten, 2007 \\
\hline Large hydro & 3 & 0,5 & 25,84 & 87,31 & Energimyndigheten, 2007 \\
\hline Biogas & 0,7 & 0,3 & 76,57 & 233,65 & Värmeforsk, 2006 \\
\hline Bio waste & 1,08 & 0,3 & 192,82 & 259,78 & Profu, 2007 \\
\hline Photovoltic & 1,5 & 0,3 & 200,85 & 235,5 & Profu, 2007 and OPTRES, 2006 \\
\hline
\end{tabular}

The interviewed Swedish stakeholders are optimistic on the Swedish RES potential and state that it is more a question of political will and target setting whether the potential is realisable.

Based on the overview on the RES-E potential and costs given above, it is clear that the potential to increase renewable electricity production in the Nordic area is remarkable. However, the potential available - especially relatively cheap - in countries vary significantly.

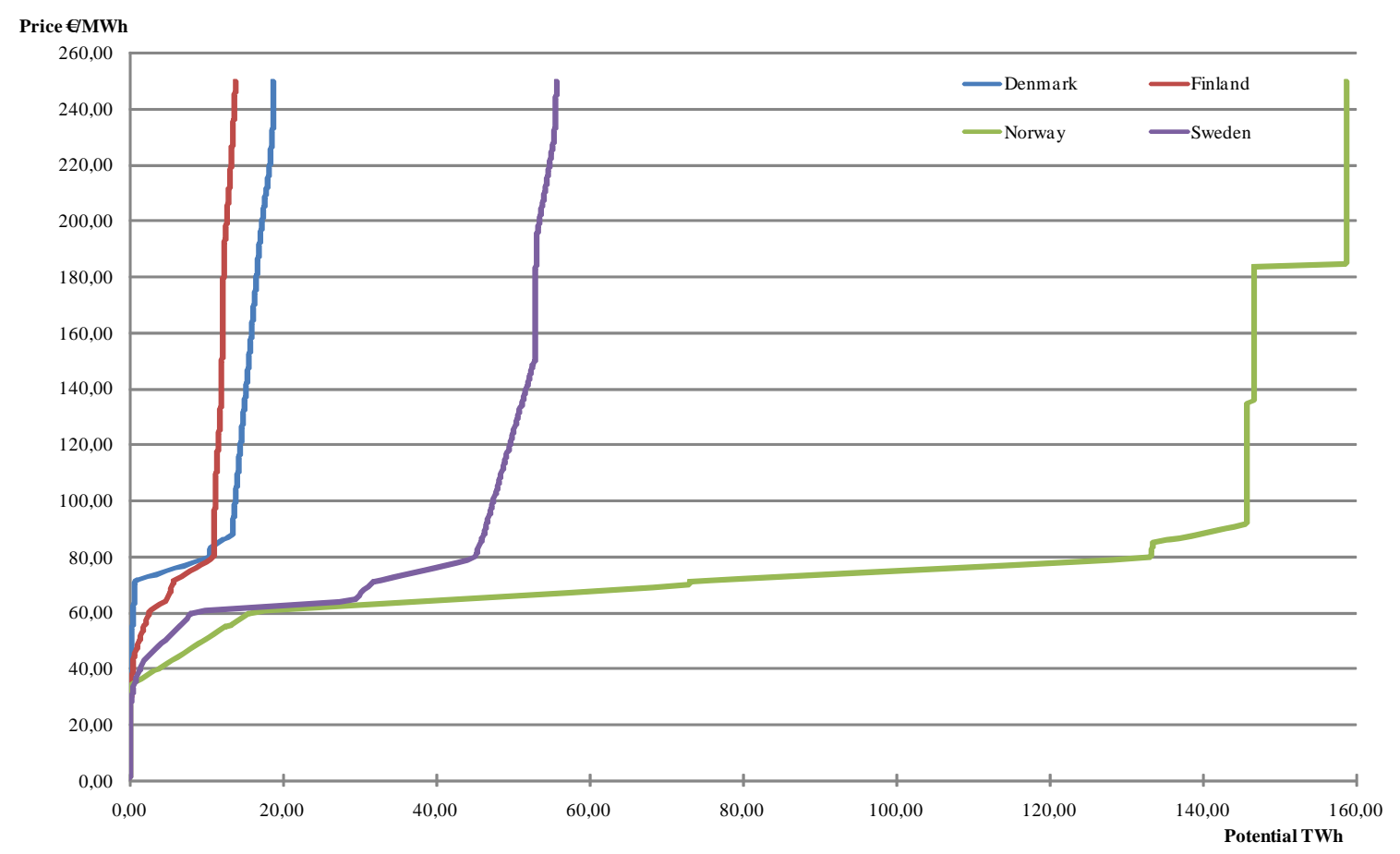

Figure 4 Marginal costs for RES-E production in Nordic countries excluding Iceland. 
Figure 4 compares the marginal cost curves of each Nordic country's potential. Under cost of $63 € / T W h$ Norway is able to implement new capacity (mainly small hydro) the most, amount close to $20 \mathrm{TWh}$. After that Sweden is able to produce the next 45 TWh with the lowest cost under $65 € / T W h$. This bulk comes from the estimated increase in onshore wind production. As discussed before, this bulk however includes restrictions that need to be taken into consideration. First, building such amount of production requires a vast amount of new capacity in a rather short time period. At the moment, the demand for new technology is already larger than the supply and such a radical increase in demand would most likely cause blockages in availability. A second issue is the grid connections and the need for reliability that have limitations among the Nordic countries. Finally, a rapid increase in demand will most certainly affect the investment cost of new plant. These issues are taken into consideration but not given values in this analysis. The production cost for onshore wind among countries are nearly the same except in Demark where the cost range is around $20 €$ above compared to the other countries.

After that Norway takes the leading role in providing the biggest amount of capacity with price of 70 to $90 € / \mathrm{MWh}$. Within the price range Norway is able to brig around 60 TWh of new capacity. This capacity is both wind and hydro but also osmotic energy. The availability of osmotic energy does however also include some restrictions. Although the technology is considered extremely promising it is still in a developing stage and whether 12 TWh could be built by 2020 is not certain.

The potentials in Denmark and Finland are estimated to be notably lower compared to Norway and Sweden. This can also be seen in the marginal cost curve comparison where the potentials in Denmark and Finland are rather marginal compared to other two countries. In case of Finland, one must remember that the estimated potentials are considered to be very realistic and realisable by 2020 . 


\section{Analysis for a harmonised support system in the Nordic countries}

Based on the RES-E potential estimates conducted in Chapter 5, the following present's three different market simulations for the location of new investments in the Nordic area. Renewable energy increase targets were also presented in the previous Chapter but for clarification, they are presented once more in Table 7.

Table 7 Estimated total 2020 RES and RES-E increase targets for Nordic countries excluding Iceland.

\begin{tabular}{|l|c|c|}
\multicolumn{1}{c}{ Country } & $\begin{array}{c}\text { Total 2020 } \\
\text { target } \\
\text { (TWh/year) }\end{array}$ & $\begin{array}{c}\text { 2020 target for } \\
\text { electricity } \\
\text { (TWh/year) }\end{array}$ \\
\hline Denmark & 30 & 18,4 \\
\hline Finland & 30 & 12,4 \\
\hline Norway & 37 & 10,0 \\
\hline Sweden & 55 & 22,0 \\
\hline
\end{tabular}

Within the analysis, following three optimisations will be presented:

- A harmonised Nordic solution based on least cost competition

- A solution based on closed national implementation

- A solution based on technology segmented Nordic implementation

Each of the three optimisations registers:

- The distribution of investments in technologies and national locations

- The total costs

- The marginal price at the end point (in 2020)

\subsection{Harmonised versus a non-harmonised solution}

\subsubsection{A harmonised, free market solution}

Assuming harmonised and liberalised market conditions as well as restrictions for available resources presented in Chapter 0, the quadratic optimisation model built for the analysis has found a free market solution illustrated in Figure 15. In the analysis, three production forms are as- 
sumed; hydro, wind and bio. The last one is the biomass, biogas and bio waste potentials combined.

In the free market solution the cheapest resources are utilised first to create new capacity. Since the model has no restrictions on concerning the grid access and other, real situation restrictions, the presented solution must be assumed as the best possible case. In reality, there would be numerous restrictions but in this context we confine our self to principal discussions about harmonisation, hence such limitations are ignored.

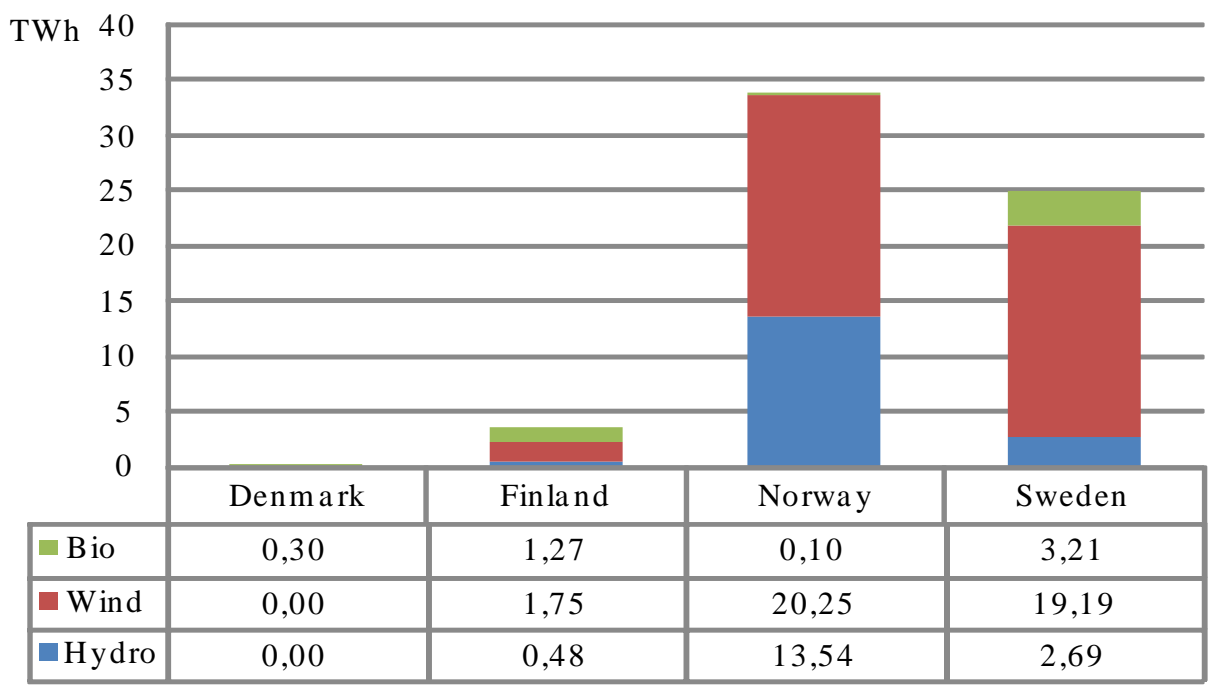

Figure 5 Distribution of new RES capacity in the Nordic countries under a free market solution.

As Figure 5 shows, the distribution of new capacity is uneven among Nordic countries. Average volume weighted price under the solution is 60 $€ / \mathrm{MWh}$, that is average long run marginal cost (LRMC) over all realised technologies. Highest observed price is around $65 € / \mathrm{MWh}$. It is likely that this price will be reached by 2020 which implies that certificate prices should be in the close to $20 € / \mathrm{MWh}$ since the power price is assumed to be $45 € / \mathrm{MWh}$. All prices are 2008 real prices.

If a completely free market solution is chosen, Norway and Sweden will host most of the new production. As mentioned, there is now restriction on the optimisation; hence factors such as security of supply and grid access are not taken into consideration. The distribution of new capacity would most likely change if these factors would be included into the analysis.

Losers in the free market solution are immature technologies as the market solution would not deliver support high enough for them to become profitable and consequently, they are pushed out of the market. As stated above, the biggest bulk of new capacity would come from wind power and Norway and Sweden will host most of the production. In terms of investment, this adds up to nearly $95 \%$ for Norway and Sweden com- 
bined. From industry perspective, this will lead to a large boost for hydro power industry in Norway, or at least to the developers. Same can be said about the wind in Norway and Sweden, but investment wise cost for wind-farms is to $70-80 \%$ constituted of the wind-mills. With exception of Vestas the Danish wind-mill producers, money invested in wind-farms will to a large extent end up outside the Nordic area. To a certain degree this also applies for hydro power since many turbine and generator producers are located outside the Nordic area.

If looking closer to the numbers, the free market solution gives close to 42 TWh of wind-power production. Even though the Nordic area is well supplied when it comes to balancing power due to a large proportion of hydropower, this 42 TWh implies nearly $16000 \mathrm{MW}$ of installed wind capacity. For grid stability such an amount of wind is likely to cause problems. This could mean that balancing power could become a scarce resource in the Nordic market in future. In addition, the main share of new hydro power will have a poor regulation capacity and hence it will use the same balancing capacity - the exiting large hydropower in the Nordic region constitute. Energy wise there is now doubt that any increase in production will enhance security of supply, assuming that most of the existing capacity remains.

\subsubsection{A non-harmonised solution}

Under this solution it's assumed that each country meets RES increase requirements with domestic measures, without co-operation. By definition, this will be the most expensive solution available, since there is no co-ordination between the Nordic countries. The RES-targets for the countries are the same as in the free market solution and no other restrictions are assumed to exist.

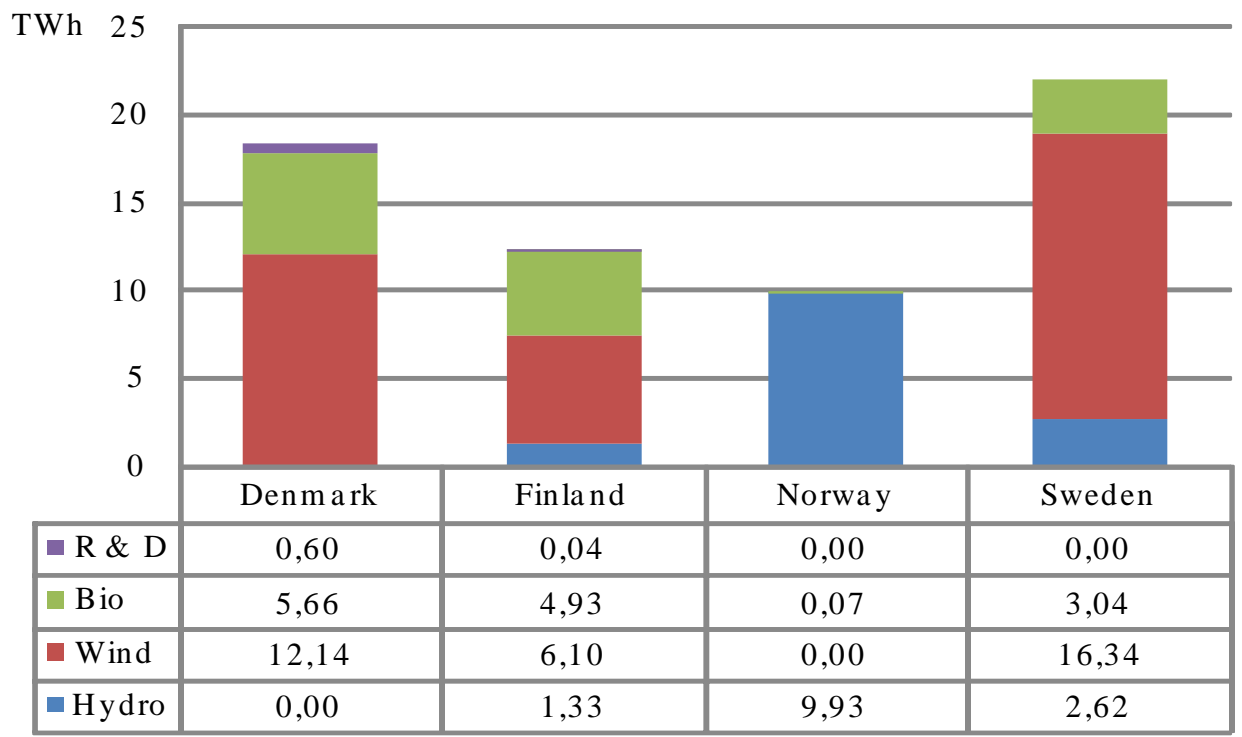

Figure 6 Distribution of new RES capacity in Nordic countries under a non-harmonised market solution. 
As Figure 6 shows none of the countries have difficulties in meeting their targets under the given circumstances. The amount of new investments inevitably decreases most dramatically in Norway and also in some extent in Sweden and respectively increases in Finland and in Denmark. In Sweden, the share of each technology remains the same compared to free market solution and wind power maintains its leading role in providing new capacity. In Norway, the non-harmonised solution would cut all new wind capacity production and the target would be fulfilled almost completely with hydro power. This again results from the relatively cheap and large hydro potential that Norway has and consequently the cost for Norway is reduced compared to free market case. Estimated price for Norway under this solution is approximately $50 € /$ MWh in LRMC.

In the Nordic level, the non-harmonised solution is the most expensive when comparing to previously presented harmonised solution or the following technology segmented solution. We estimate that the average LRMC is approximately $83 € / M W h$. This price is the upper limit of the price (unless further technology restrictions for each country are placed).

Sweden has almost the same situation as Norway though it cannot rely in the same extent on hydro-power and hence the marginal technology in Sweden is wind with a LRMC price of approximately $61 € / M W h$. From the Swedish consumer point of view, the non-harmonised solution would bring only $1 € /$ MWh more cost compared to the harmonised solution.

As expected, increased cost of the non-cooperation must be carried by Danish and Finnish consumers and they face a substantial increase in the costs. Average LRMC cost in Denmark will reach approximately 127 $€ / \mathrm{MWh}$ and for Finland it close to $86 € / \mathrm{MWh}$ (all prices in 2008 values). Increased costs are due to fact that each country must reach their targets with domestic measures. With ambitious target, countries might be forced to use technologies that can be considered to be currently in R \& D stage.

On the other hand, domestic solution implies that investments are located according to RES-targets. More specifically, Denmark will fully utilise its wind potential, and all other sources for renewable energy for power-production within the country. A similar situation appears in Finland. A common feature for both countries is that they must invest in a rapid phase, since the targets are set for 2020. As a consequence, this might leave both Denmark and Finland vulnerable for disruption and delays in investments that might arise from the supply crunch on windmills or similar reasons.

For Norway and Sweden the situation is close to opposite - investments can be done in a slow pace do to the large amount of renewable energy resources available in both countries. 


\subsection{A technology segmented market solution}

In a technology specific market solution we make an assumption of the amount of production from each technology at the end of year 2020. We assume an equal distribution of $30 \%$ for hydro, wind and bio power. In addition, there is a $10 \%$ share left for technologies at the developing stage named as R\&D in the analysis. This sharing among the Nordic countries is done based on an assumption that there is a need to increase the share of bio energy and reduce the dependency on wind power compared to harmonised solution.

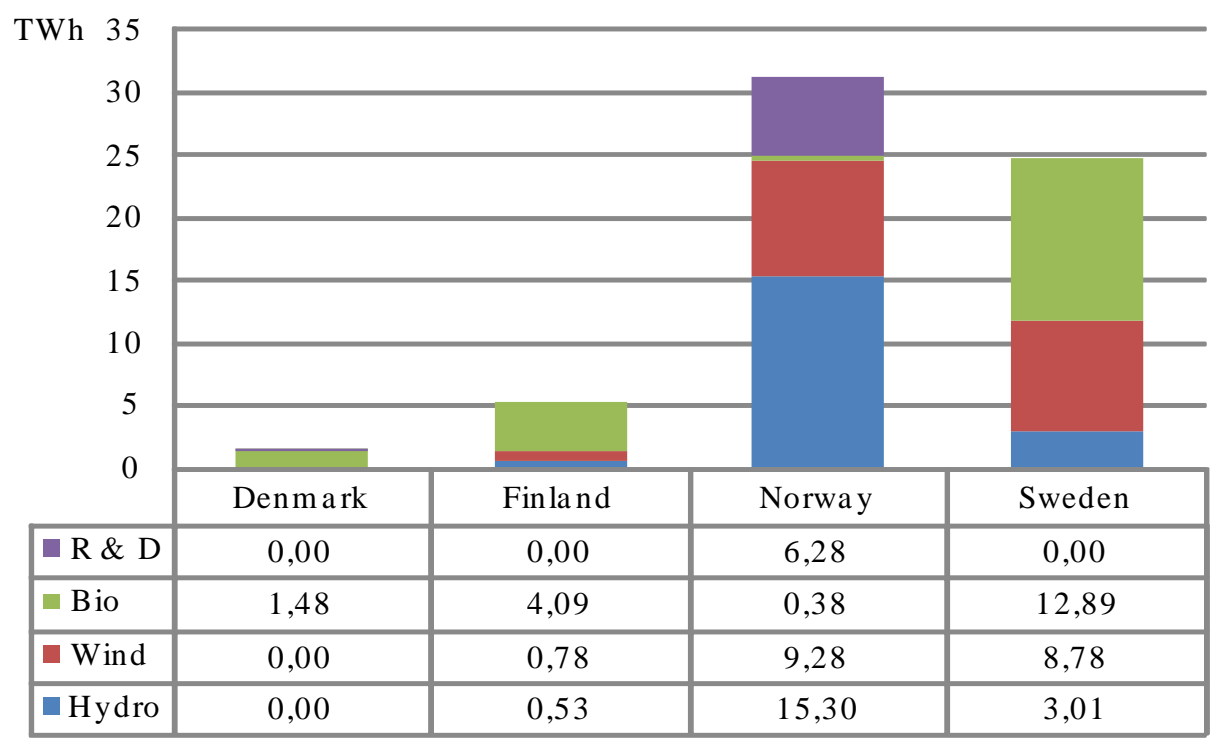

Figure 7 Distribution of new RES capacity in Nordic countries under a technology segmented market solution.

As the Figure 7 above shows the distribution of production between the Nordic countries does not change significantly compared to the free market solution. However, forcing more bio energy to the market does increase the share of Denmark and Finland in the solution. In addition, the share of wind power decreases and respectively the share of Norwegian hydro power increases. Assuming a certain market share for R\&D technologies introduces some new technologies to the market - mainly Norwegian osmotic power. The overwhelming position is due to lower cost compared to other technologies.

The costs under the technology segmented solution decreases compared to the non-harmonised solution. The average price for the Nordic region is estimated to be approximately $71 € / \mathrm{MWh}$, which is between the $61 € / \mathrm{MWh}$ for the free market solution and $83 € / \mathrm{MWh}$ for the nonharmonised solution.

In investment wise the total share in production volume in Denmark and Finland increases from approximately $6 \%$ to $10 \%$ compared to free 
market solution. In addition, some production is also shifted from Sweden to Norway which results from the increased share of hydro power that was assumed in this solution.

The technology segmented market solution illustrates that dividing investment targets over different technologies will change the outcome but, in general, the main results of the free market solution apply also to this solution as most of the new investments are directed to Norway and Sweden. This would also imply that Norway and Sweden will benefit the most when it comes to number of workplaces and employment related to renewable energy investments.

A focal reason for the uneven distribution of new production under technology segmented and especially under the free market solution are the differences in the maturity and costs for utilising renewable energy sources in different countries. Denmark has a relatively long history on supporting wind production with feed-in tariffs and as a result, cheap and good locations for wind mills are no longer easily available.

In term of diversification over technologies, the technology segmented solution offers less diversification than the non-harmonised solution but more than the free marked solution. Still, the increased share of bio energy also leads to a greater dependency on the availability of biomass. However in this case, it is biomass in the whole Nordic area, and hence there should be some more flexibility than in a non-harmonised solution.

Despite the changes in the solutions the principal results of the free market solution apply also to the technology segmented solution and there by highlight the fact that renewable energy resources, in fact, are unevenly distributed over the Nordic region. The segmented market system would lead to increased technology diversification but would still not divide it evenly among the Nordic countries.

\subsection{A harmonised feed-in tariff versus a green certificate scheme}

There has been considerable debate about the feed-in systems versus certificate/cap and trade systems in the European context. Both systems have their merits, and the challenge lies very much in the detailed design of the system. The scale and scope of this study does not allow us to pursue any comprehensive analysis on Nordic feed-in or certificate models. However, based on the renewable energy increase potentials presented in Chapter 0 , a simplified illustration is made to highlight some of the challenges that a feed-in system compared to a cap and trade based solution have.

In it is simplest form, a feed-in system has many advantages both from an investor and regulator point of view as described in Chapter 0 . Normally feed-in systems are utilised on a country level and they head to 
support specific technologies. If considering a feed-in system that would apply over a joint Nordic market for RES technologies, the feed-in prices would be a function of the RES-target. The required feed-in price in a joint market is therefore a function of the development cost at the time the feed-in scheme is decided on.

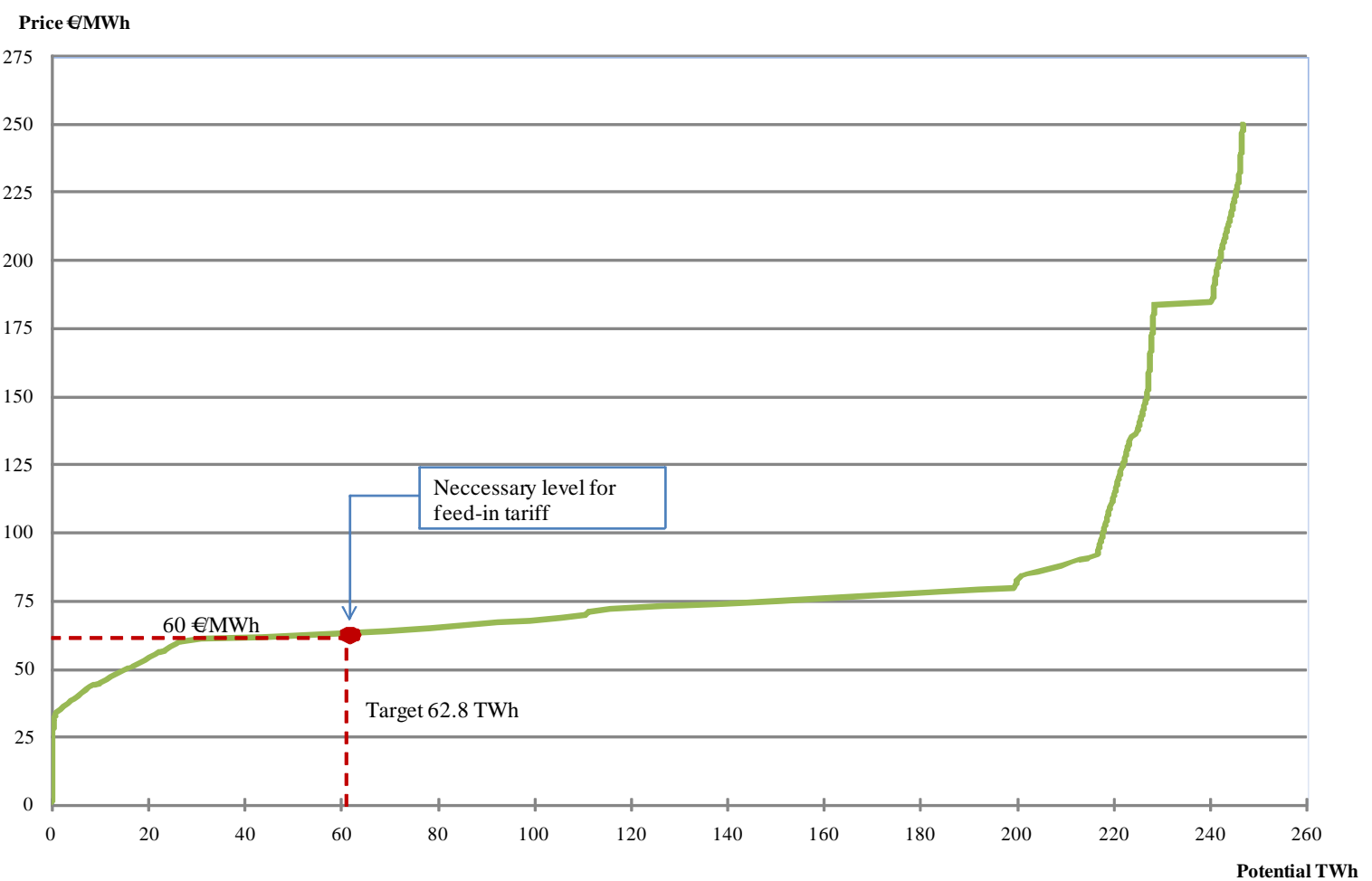

Figure 8 A long run marginal cost curve for the Nordic RES-E potential and the necessary support level under a harmonised feed-in tariff system.

A common feed-in tariff support system in Nordic countries would bring the cheapest volume/technology to the market first, until the target is reached. The price is therefore equal to the free market solution. The difference between the feed-in system and the dynamic market solution is that the price under a market based solution does not jump immediately to the maximum level as in the feed-in scheme.

The high price under a tariff scheme will generate windfall profits to some power producers. Basically all renewable production receives the highest price in the merit order curve.

As shown in Figure 8, the combined RES increase target of $62.8 \mathrm{TWh}$ could be reached with a support level of $64 € / M W h$. Even though feed-in tariff would be agreed prior to 2010, it would not necessary ensure that target would be achieved without further adjustment in the feed-in tariff level. Feed-in systems are static in their nature and do not take in to account the possible future increase for example in the wind technology prices. Under already implemented feed-in schemes adjustment may not 
have been necessary but applying strong policies and measures at the same time in many countries is likely to change the demand of RES technologies and required human capital radically. A market based system would ensure that the goal would be achieved as the prices are adjusted in the market based on demand set by the interim and final RES-targets.

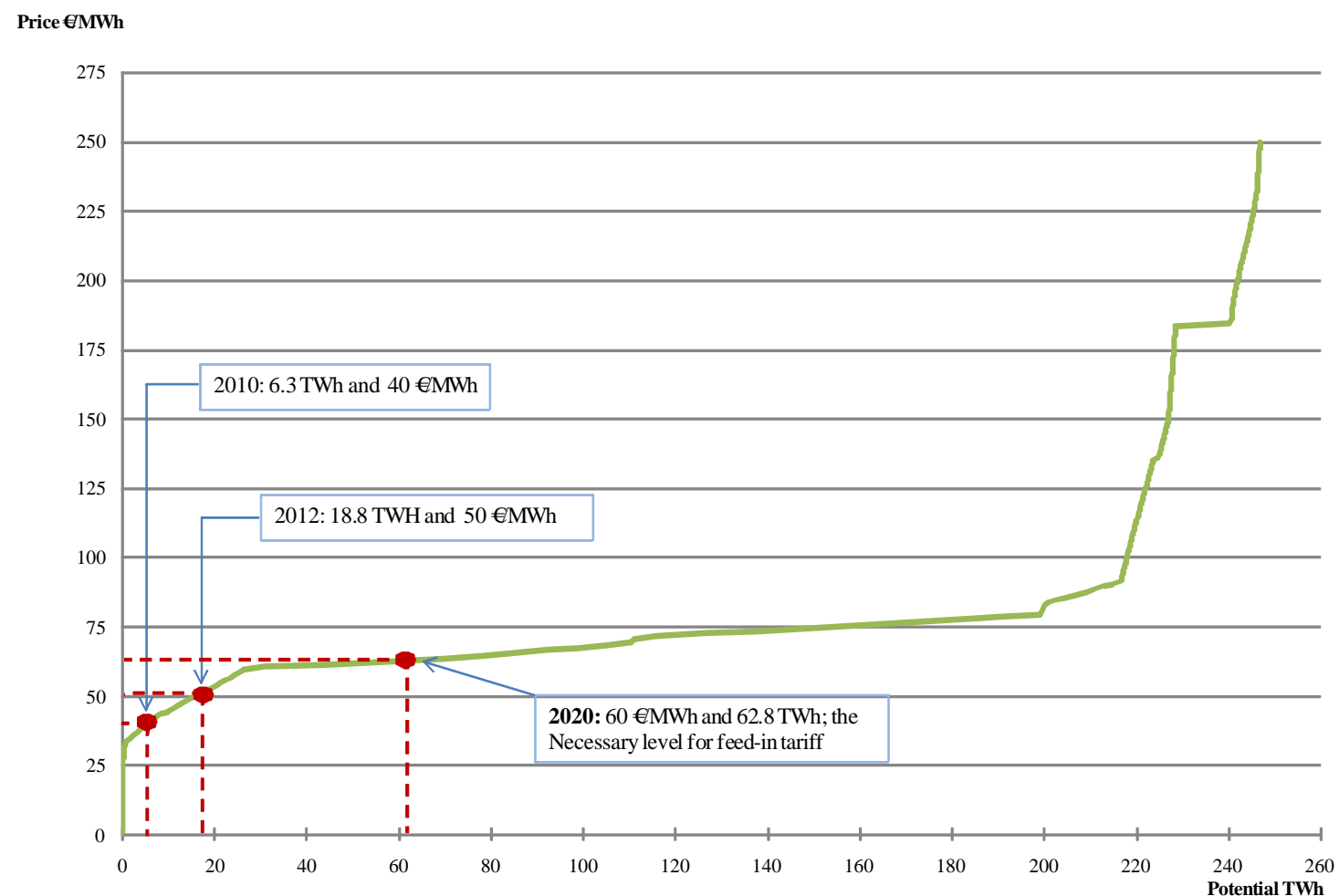

Figure 9 A long run marginal cost curve for the RES potential in the Nordic countries (excluding Iceland) and the necessary support level under a harmonised feed-in tariff system.

Assuming that countries would have an interim, linear increase target from zero towards the 62.8 TWh target, possible price in 2010 could be $43 € / \mathrm{MWh}$ for the first 6.8 TWh on the way toward 62.8 TWh. In 2012 the interim target is assumed to be 18.8 TWh, and give us a corresponding price of $53 € / \mathrm{MWh}$.

As indicated in Figure 9, the first 30 TWh of potential is available over a rather wide price range but after that the amount of available potential increases without the price increasing notably. This bulk of equal price potential are the onshore wind mills that became profitable. The potential's price sensitivity is high; small changes in the subsidy level can release or remove a large volume of wind power investments. This applies also for other technologies and, consequently, the potential curve is steep. This highlights the weak point that feed-in schemes have for minor 
changes in the costs, thus the feed-in-tariff is easily set either too low or too high.

In a feed-in scheme, the market risk is transferred to those who are paying for the scheme and the power prices that decreased due to increased supply are compensated to the producer. This typical character of feed-in schemes does not increase the liability of the system. Hence the risk of oversupply of renewable energy is therefore a characteristic of a feed-in scheme which again can affect the balance of the power markets.

The steep potential curve indicates that the support level in a feed-in scheme must be set in a so high level that many producers would end up receiving wind fall profits. On the other hand, there is now doubt that the RES target would not be achieved under a joint Nordic support feed-in scheme if the subsidy level is too high. Costs from the feed-in system would probably be substantial since there must be some margin in the tariff level that takes into account risk of increasing technology prices etc. Applying a feed-in scheme on a national level has the same problem except the cost would be lower for some countries and higher for other. These costs are determined by the national power production merit order curves and the targets. Based on the analysis, a possible Nordic level harmonised feed-in system should be limited to only certain technologies.

Even though a tradable certificate system has advantages compared to feed-in tariffs when it comes to price dynamics, the shape of the Nordic RES potential curve (mainly due to the bulk of wind potential) removes some of this advantage under a free market solution. Hence the difference between a completely market based system and a feed-in system is not as big as it could be if the curve had a different shape.

Still, based on the analysis a dynamic system would be more suitable for harmonisation and, at the same time, guarantee lower total costs. But again, overall functionality of the system extremely dependent on how the system is built up.

\subsection{Sensitivity analysis}

To evaluate the stability of the presented solutions in previous sections a sensitivity analysis is conducted. The technology segmented market scenario is used as a base case for the analysis. The technology segmented market solution assumes that $30 \%$ of new capacity is hydro power, $30 \%$ wind power and $30 \%$ is bio (biomass and bio gas). The remaining $10 \%$ is assumed to come from the $\mathrm{R} \& \mathrm{D}$ technologies.

We have done calculation for six different scenarios to study the effects of different assumptions. These assumptions are listed below. All potentials refer to what can be expected to be invested before 2020 . 
- Scenario 1: Wind potential in Norway and Sweden is restricted to 20 TWh. Distribution between onshore and offshore is assumed to be 14 TWh and 6 TWh in both Norway and Sweden.

- Scenario 2: Wind potential in Norway and Sweden is restricted to 15 TWh Distribution between onshore and offshore is assumed to be 10 TWh and 5 TWh in both Norway and Sweden. In addition, potential for small hydro in Norway is restricted to 10 TWh.

- - Scenario 3: Wind potential in Finland is increased to total of 10 TWh and the increase is implemented as onshore potential.

- Scenario 4: Norway's RES-target is increased from 10 TWh to 15 TWh.

- Scenario 5: Each country's RES-target is increased by $20 \%$.

- Scenario 6: Each country's RES-target is decreased by $20 \%$.

The results of the sensitivity analysis are in line with our expectations, and correspond to the structure of cost, and how resources are divided among the Nordic countries.

Table 8 The distribution of market share among Nordic countries under sensitivity analysis scenarios.

\begin{tabular}{|l|c|c|c|c|l|}
\hline \multicolumn{5}{|c|}{ Market share from total RES-volume in 2020} \\
\hline & Denmark & Finland & Norway & Sweden & \multicolumn{1}{|c|}{ Description } \\
\hline Base case & $2,4 \%$ & $8,8 \%$ & $48,8 \%$ & $40,0 \%$ & Base case, technology segmented market solution \\
\hline Scenario 1 & $2,4 \%$ & $8,9 \%$ & $48,8 \%$ & $40,0 \%$ & Wind potential is set to 20 TWh in Norway and Sweden \\
\hline Scenario 2 & $2,4 \%$ & $11,4 \%$ & $42,2 \%$ & $44,0 \%$ & Wind to 15 TWh in Sweden and Norway; small hydro in Norway to 10 TWh \\
\hline Scenario 3 & $2,4 \%$ & $11,2 \%$ & $47,6 \%$ & $38,9 \%$ & Finland's wind potential increased to 10 TWh \\
\hline Scenario 4 & $2,6 \%$ & $8,7 \%$ & $49,1 \%$ & $39,6 \%$ & Norway's RES-target increased to 15 TWh \\
\hline Scenario 5 & $3,0 \%$ & $8,2 \%$ & $49,4 \%$ & $39,3 \%$ & Each country's RES-target is increased by $20 \%$ \\
\hline Scenario 6 & $4,1 \%$ & $11,3 \%$ & $46,7 \%$ & $37,8 \%$ & Each country's RES-target is decreased by $20 \%$ \\
\hline
\end{tabular}

As Table 8 shows, the solutions do not radically differ from the base case. The largest change is in Scenario 2 if both Norway's and Sweden's wind potential is restricted to $20 \mathrm{TWh}$. Under this assumption, Norway will lose $6.6 \%$ of its market share compared to the base case. A more detailed presentation of the results for each scenario is in Annex 5.

Based on the sensitivity analysis it is clear that changes in potentials do not affect the market solution in a dramatic way when it comes to distribution of new capacity among countries. The main reason for this is in new hydro power capacity that can be built with notably lower costs than any other technology. This bulk of cheap potential is available in every scenario thus the changes in scenarios are caused by other, less influential technologies.

When it comes to power production from bio or wind the outcome is not as obvious since there is some overlap with these two technologies regarding the long run marginal cost curve. Some of the bio potential will 
occur at a low cost and can be produced at a lower cost than onshore wind power.

An important question is how the wind production is distributed in each scenario. Since cost for wind power is very dependent on cost of wind mill investments and almost all other economical factors are the same over the Nordic region, cost in the Nordic region are almost equal. Thus even small differences in costs can shift a vast volume of wind production from Norway to Sweden and vice versa. Again this would not change the principal result that wind production is the dominant technology in a harmonised scheme. In this study it is assumed that wind power is slightly cheaper in Sweden and following this, the majority of wind developments take place in Sweden.

It is also worth noticing that the share of renewable production in Denmark remains low in every scenario. As mentioned before, this is a result of the effort done by the Danes earlier on the renewable energy cheap renewable energy is not available as the most economic sites and resources are already utilised.

In the base case, in Finland the available wind power is low and consequently the share of overall wind production is low. Increasing wind potential to 10 TWh in Finland does increase its share even though the new potential would not be completely utilised. The results from Scenario 6 also show that the cheap bio energy is utilised before the more expensive wind which would increase the share of the total RES-production if RES targets are lowered with $20 \%$.

Based on the cost curves which are used and the conducted sensitivity analysis the solution under the base case is representative. Major changes in LRMC curves must take place in order to change the principal solution significantly. Such a change must be a notable increase/decrease in costs of wind technology and an opposite development for bio energy costs. Under such an event the solution would move towards more/less bio energy and again an opposite change in the share of wind power. 



\section{Impacts of harmonisation}

Based on the analysis conducted in Chapter 0 the following sections draw together the estimated main impacts harmonising renewable energy policy would have on security of supply, labour and electricity market in the Nordic countries. Within the latter topic, questions related to possible need for network extensions, regulation capacity, system cervices as well as the restrictions related to a large amount of wind capacity in the grid are discussed. The impacts will be examined in a qualitative level utilising also previous studies related to topic.

The focus of the impact analysis will be on increased wind capacity as it is estimated to have the leading role in a harmonised scheme - as shown in previous Chapter 0 .

\subsection{Security of supply}

Expectations of higher dependency on energy import and increasing oil and gas prices have lead to an increased concern about the security of supply in both EU-level as well as in national discussions. For the producers of renewable energy this can however be considered as a positive thing - at least as long as it increases the importance of renewables. When it comes to possible harmonisation of RES support systems among countries, the possible country level impacts on security of supply is a complicated issue to analyse due to the fact that the debate of security of supply is primarily focused to a European level, whereas other related issues such as industrial and technology policies are still focused to a national level.

A previous study that has been executed on this topic on EU level ${ }^{9}$ has shown that the Member States do also consider their longer term security of supply position when it comes to designing support for renewable energy. Renewables are assumed to contribute to the future energy resource portfolio in the EU and each Member State would prefer a beneficiary position in this respect. Thus most countries do have a specific interest to have RES-E production capacity within the national borders.

The Nordic countries have considered security of supply and renewable energy in their energy policies as follows. In Finland the question of security of supply has become even more important within recent years. In 1997 the Finnish government approved the Finnish Energy Strategy,

\footnotetext{
${ }^{9}$ COMMUNICATION FROM THE COMMISSION, 2005. COM (2005) 627. The support of electricity from renewable energy sources.
} 
where the overall goal was to lower the carbon emissions from energy production and to increase the security of supply. To reach this goal the position of renewable energy and other indigenous energy sources, like nuclear power, are stated as important. In Denmark the industry is very concerned about the status of security of supply. According to previous studies, the Danish industry wishes to see a stronger focus on security of supply and that the issue is also discussed at a European level. (Middtun \& Gautesen, 2006).

In the Swedish energy policy, the long term target is to obtain all energy from renewable energy sources. In a report from the government (Renewable electricity with green certificates, 2006) the government states that the continued transformation of the energy system and high security of supply are the two most important reasons to promote electricity production from renewable energy sources in Sweden. Also the Swedish energy industry points out that the current Swedish certificate system has an explicit goal of providing green energy, but that it also has the advantage of increasing security of supply in the Swedish and Nordic region (Middtun \& Gautesen, 2006).

In Norway there seems to be a social interest in promoting both gas power and the certificate system for renewables. Some would argue that with a very ambitious certificate system, the gas would be superfluous but on the other hand this would also increase the security of supply and Norway could again be a net exporter of electricity (Middtun \& Gautesen, 2006).

In regards to a certificate system it is important to notice that a lot of the renewable production that will come online due to the support of a green certificate scheme will not have the ability to regulate. This could propose new challenges around the issue of long term security of supply and increase the demand for regulated power production. If the responsible TSO have to buy more production in the regulated power market, this could lead to higher power prices for the consumers. (NVE report, 2004)

The possible evaluation of possible impacts a harmonised support system would eventually have on national security of supply is an issue that should be evaluated more profoundly in case Nordic harmonisation is realised. Based on the analysis made Chapter 0 it is possible that the differences in potentials and costs among Nordic countries could decrease the level of RES capacity in some country to a level which is considered critical to the security of supply. Among the interviewed stakeholders none really raised this to an issue that at this point of consideration is a barrier for further development. Still, especially among the administration respondents the linkage between possibly decreasing national capacity and security of supply was recognised. 


\subsection{Labour}

The European Renewable Energy Council (2007) estimates, that the 2020-targets could increase the employment in the RES sectors up to 2 million by $2020^{10}$. Over half of this amount would be located in the biomass and bio fuel sectors whereas the share of wind industry would be 318000 and hydro 28000 . The rest is expected to come from more developing technologies such as photovoltaic and solar thermal.

In the Nordic countries wind power is estimated to bring the biggest share of new RES to the market regardless whether the support system is harmonised or not. Following this, looking at the possible employment effect new wind capacity would have is reasonable. According to Jacobsen (2004) the employment effect for installing a new wind turbine is between 2 to 9 employees per MW leading to an average of 6 employees per $\mathrm{MW}^{11}$. The operation and maintenance of the installation has an effect of 0.1-0.45 employees per MW and average of 0.28 employees per MW. The values are the effects that follow directly ${ }^{12}$ from new capacity building. The building stage of new plant is clearly the important part from the employment point of view.

In following, the labour impact of new wind capacity in Nordic countries is evaluated. From the employee effects presented above, an average of 6 employees per MW is utilised for each country. For the calculation, an average availability rate of $0.3^{13}$ for the installed capacity is used. Table 9 shows the employment effect of expected new wind capacity under harmonised, non-harmonised and under a technology segmented solution. The estimated figures are indicative and should not be considered as absolute values.

Table 9 The employment effect of a harmonised, non-harmonised and a segmented market solution.

\begin{tabular}{|l|c|c|c|c|c|c|}
\hline \multicolumn{4}{c}{ Harmonised solution } & \multicolumn{2}{c}{ Non-harmonised solution } & \multicolumn{2}{c|}{ Segmented solution } \\
\multicolumn{1}{|c|}{ MW } & employment & MW & employment & MW & employment \\
\hline Denmark & 0 & 0 & 4613 & 27679 & 0 & 0 \\
\hline Finland & 665 & 3990 & 2318 & 13908 & 296 & 1778 \\
\hline Norway & 7695 & 46170 & 0 & 0 & 3526 & 21158 \\
\hline Sweden & 7292 & 43753 & 6209 & 37255 & 3336 & 20018 \\
\hline
\end{tabular}

\footnotetext{
${ }^{10}$ The estimate includes both direct and indirect employment and is counted as full time employment.

${ }^{11}$ The employment effects have been calculated using the input-output methodology. For further information, please see reference.

${ }^{12}$ Direct effect relates to employment with wind turbine manufacturing companies and subcontractors whose main activity is to supply components related to wind turbines (Jacobsen, 2004).

${ }^{13}$ The estimated availability rate for all onshore and offshore potential in Nordic Countries varies between $0.22-0.34$
} 
To estimate the magnitude of the employment effect presented in Table 9 one can compare the figures to similar that describe the development of Denmark's wind industry. The employment in the Danish wind industry has increased from 9650 in 1996 to 21612 by 2006 (Danish Wind Industry Association, 2008). Under a harmonised situation, the employment effect in Norway and in Sweden would be over twice the size compared to the development in Denmark. If Nordic countries reach the targets with national measures, the wind industry employment effect is distributed more evenly - only Norway has a zero effect as practically all new capacity is estimated to be hydro power. Finally under technology segmented solution most of the effect is again in Norway and Sweden but with less extent since the expected installed wind capacity is smaller than under harmonisation.

In addition to wind capacity, also increasing utilisation of biomass is expected to have a notable impact on labour. If no new capacity for utilisation is required the biggest impact will be on producing the fuel. If new capacity again is needed, as was for example estimated for the second half of Sweden's biomass potential, the building state would naturally have a significant impact on employment. For other technologies, the evaluation of labour impact would require more thought full analysis before conclusions could be made.

The presented figures for wind give a rather optimistic picture of the impact increasing RES capacity has in the Nordic countries. Still, to evaluate the overall impact of harmonisation and the increasing share of RES might have a more profound macro economic analysis would be required. According to Pfaffenberger et al (2006) the positive labour effect in the RES sector is from some parts decreased due to job reduction in other sectors that follows from the displacement of financial resources. Overall, increasing RES share is not seen as a "job machine" in a macroeconomic level but it is clear that notably labour increase in relevant sectors can be expected.

\subsection{Electricity Markets}

In theory, support schemes such as feed-in tariffs and green certificates introduce extra production to market that is already fully supplied. This would lead to decreasing market prices as the supply increases. However, if for example the buying obligation under certificate system is set very high the effect can be adverse compared to the theoretical outcome. In the initial stage of the scheme the electricity price will fall but as the mandatory buying obligations are increased over time, the certificate price will as well increase. Under these conditions, the electricity price will end up to a higher level than it was before the support scheme was introduced. 
Feed-in support system can be designed in many different ways, and hence the impact from such scheme has equally many outcomes in price as there are system designs. Given the set of more or less mature technologies available for energy production, settling in to one common feedin-tariff is not economically viable.

Such general fee-in tariff support would lead to the following: all production capacity with net present value above zero would be realised, or at least in theory. This would lead to a rapid building of new production facilities and, assuming no limitation for any technology, would mean a massive increase in construction of small scale hydro power and windmill farms. Under this situation the diversity of production technologies would not improve, hence the development of some technologies would suffer.

Within the presented scheme the development of consumer prices is dependent on the level of support. In Nordic level, this could lead to a situation where the market is facing extremely high supply from wind and small hydro-electric production; or geothermal energy if Iceland is included to the scheme. This is due to fact that the available potential for these technologies in the Nordic exceed by a large margin any goal for renewable set by proposed by the European Commission.

\subsection{Grid issues}

The most important grid issues that need to be taken into consideration in the context of harmonisation are access to grid, capacity of energy transportation and regulating capacity. For example Elforsk (2008) estimated that in a longer perspective Swedish electricity production could be maximum 30\% from wind power due to grid restrictions. Wind-mill farms access to transport energy and regulating power are important factors which often are highlighted in various discussions.

The grid issues and associated costs will arise regardless whether new renewable production support is harmonised or not in the Nordic countries. For the latter, there is now doubt where cost should be allocated, and cost will be carried of consumers in the respective country. In a harmonised system the answer to question who should bear the costs in investments in the grid, is not so obvious, and detailed calculation on who has the benefit of a new power-line must be carried out. Even under this assumption, the burden sharing between the countries will be a difficult question to solve. A common transmission system operator (TSO) in the Nordic area could of course make matters like this easier to solve.

Grid issues are one of the biggest obstacles in building sufficient amount of renewable energy. Who will get access, is it going to be a first come, first serve system, or should developer take part of the cost? All these questions must be answered in order to facilitate for a large scale development of renewable energy in the Nordic area and this requires an 
extensive dialogue between the Nordic countries and stakeholders. The ambitious RES targets will make this issues necessary to be addressed regardless of if there is going to be a harmonised system for renewable energy or a non-harmonised system.

Following this, grid issues are probably the most important single item that has to be addressed in order to support a large scale development of new renewable energy in the Nordic area or in each country, if a nonharmonised solution for renewable energy development is chosen. Grid issues must be evaluated as an integrated part of the question of harmonisation of renewable energy in the Nordic region - not after there is a decision on a harmonised support system for renewable. Until then grid problems remain mainly as a national question.

By and large, detailed calculation of the grid requirements requires a vast amount of data, and prognosis on where power production will be located and the detailed characteristic of production patterns etc. Hence, a necessary step before making a decision about how the grid is going to look like is to estimate exact location of the new investments. 


\section{Conclusions}

Nordic countries have long co-operated on energy issues and Denmark, Finland, Norway and Sweden have a common electricity market. Harmonisation of the schemes for promoting the use of renewable energy sources (RES) has been on the agenda and it has been estimated that harmonisation can improve market conditions for trading with renewable electricity and efficiency of the markets. In order to analyse the consequences of harmonised scheme we have developed various harmonisation scenarios:

- A harmonised Nordic solution based on least cost competition

- A solution based on closed national implementation

- A solution based on technology segmented Nordic implementation

The three scenarios have a common factor - they all result a large amount of wind power investments. A resemblance which is a consequence of the given potential of renewable energy present in the Nordic area. Cost structure compared to other technologies does also matter in this equation and, except for hydropower production, wind power productions units seem to hold an advantage compared to other technologies.

Due to this, all solutions are dominated by wind unless restricting production from wind-mills. In the free, harmonised market solution the share of wind production is $44 \mathrm{TWh}$, that is $70 \%$ of the total required (62.8 TWh) RES-E-production. Even under the restriction that RES target must be fulfilled with national measures the total share of wind is close to $35 \mathrm{TWh}$, which constitute nearly $56 \%$ of the total RES target within the Nordic-area. Only when restrictions on how much each technology can contribute, that is the technology segmented market solution, the share of wind power production consequently decreases.

Based on the analysis a market based, harmonised support system will result a rather uneven distribution of new production among the Nordic countries even if the share of new wind power is limited. This is due to the relative advantages both Norway and Sweden have for wind and hydro energy production costs and potential. The distribution of new capacity naturally raises questions of the uneven distribution of benefits among the countries. Implementing a joint feed-in tariff system in the Nordic area will face the same problems as the free market solution concerning both the distribution of technologies and the location of production; $70 \%$ of the production will come from wind mills. The biggest challenge in a feed-in tariff scheme would be setting the level of tariff since the potential curves are steep and hence can small changes in the development add or remove notable volumes in production. 
Under market based harmonisation the location of investments would be the most cost-efficient solution from purely economic point of view. Overall, if Denmark, Finland, Norway and Sweden had a fully harmonised renewable energy subsidy system the overall cost savings could increase up to magnitude 1.4 billion Euros by 2020 if the compared to case where all the countries would meet their target with domestic measures. The decision on how much weight is placed on other possible benefits and disadvantages of harmonisation than purely economic ones requires a political decision.

It is clear that a joint green certificate scheme has the best qualities to succeed when implemented in several countries. Still, equally, or even more important than choosing the right instrument is the designing and implementation phase of the possible scheme. Even if the tool would be the best possible the system is likely to fail if this phase is neglected or poorly designed.

At the moment, the main challenge for harmonisation is the fact that the renewable energy targets are set nationally and possibilities how countries could try to reach they targets with common scheme is vague. It is clearly stated among the stakeholders that as long as there is no possibility for burden sharing among Nordic countries, harmonisation is not an option since it would most likely centralise renewable energy production to certain countries. If the Directive proposal would accept an umbrella solution - harmonisation is completely another issue.

If burden sharing is allowed within the EU RES increase obligation, the next step for harmonisation is a need for a political will. The Nordic countries must be able to have the will and ability to create such a system that satisfies all countries, not just those that based on the analysis benefit the most from the system - at least investment wise. Such scheme is not likely to be purely based on single instrument such as green certificates but takes into consideration new technologies that require more support to enter the market than a single market based system could provide. Such scheme would also ensure that the research and development for new innovative energy solutions would continue in Nordic countries.

Finally, a relevant question is whether the given time limit is even close to be sufficient for building a common scheme or would a longer time scope be more relevant. Several stakeholders also raised the question whether harmonisation should take place in EU-level instead on Nordiclevel. EU-level harmonisation should be a target in a longer scope like a common electricity market is. Yet it is clear that even the building of EUlevel electricity market requires several steps and is likely to take considerably long time and hence the ground is not yet ready for a harmonised support mechanism. In this context the Nordic countries have the opportunity to be forerunners, show example and gather valuable experiences as they are doing right now with the common electricity market. 


\section{References}

Asplund, D. et al. 2005. Uusiutuvan energian lisäysmahdollisuudet Suomessa vuoteen 2015. Kauppa- ja teollisuusministeriö.

BCG, 1968. Perspectives on experience. Boston Consulting Group Inc.

Blåfall, 2008. Personal communication with Project Engineer Anna Ranmarker.

BMU, 2006. Strom aus Erneuenbaren Energien. Was kostet es uns wirklich? Bundesministerium für Umwelt, Naturschutz und Reaktorsicherheit. 3/2007.

BMU, 2007. Erfahrungsbericht 2007 zum Erneuenbaren-Energien-Gesetz (EEG) gemäss § 20 EEG, BMU Entwurf, kurzfassun. Bundesministerium für Umwelt, Naturschutz und Reaktorsicherheit, 7/2007.

Commission on Oil Independence, 2006. Making Sweden an oil free society.

Danish Wind Industry Association, 2008. Wind figures. Available on line: http://www.windpower.org/en/stats.htm

DTI, 2007. Energy Trends, May 2007. Department of Trade and Industry, UK.

ECN, 2005. Review of international experience with renewable energy obligation systems. Energy Research Centre of the Netherlands.

Elforsk, 2008. Vindkraft i framtiden. 08:17.

Energiateollisuus, 2007. Selvitys uusiutuvan energian lisäämisen kustannuksista ja edistämiskeinoista.

Energimyndigheten, 2007. this is about sweden's biomass and hydro potential

EREC, 2007. Renewable energy target for Europe - $20 \%$ by 2020. European Renewable energy Council. Document available on line:

http://www.erec-renewables.org/fileadmin/erec_docs/ Documents/Publications/EREC_Targets_2020_def.pdf

European Commission, 2008. The Energy and Climate Package 2020, related documents on line:

http://ec.europa.eu/energy/climate_act ions/index_en.htm

European Commission, 2005. COM(2005) 627. The support of electricity from renewable energy sources.

EUROSTAT, 2008. data available on line: http://epp.eurostat.ec.europa.eu

Fritz, P. 2006. Price formation of green certificates. Ten Perspectives on Nordic Energy. Final report for the first phase of the Nordic Energy Perspectives project. Chapter 11.

Jacobsen, H. 2004. Wind Energy the Facts - Industry \& Employment. Volume 3. EWEA.

Middtun, A; Gautesen, K. 2006. Electricity produced from renewable energy sources-What target are we aiming for? Energy Policy. Vol 35 issue 11. November 2007.

NEP, 2008. Nordic perspectives on the EU goals relating to $\mathrm{CO} 2$ emissions, renewables and energy efficiency first results from the NEP models, Nordic Energy Perspectives. May, 2008.

NVE, 2004a. Small hydro potential 2004. The Norwegian Water Resources and Energy Directorate.

NVE, 2004b. Elproduksjon basert på biobrensler. The Norwegian Water Resources and Energy Directorate. NVE, 2005a. Kraftbalansen mot 2020. The Norwegian Water Resources and Energy Directorate.

NVE, 2005b. Vindkraftpotensialet in Norge. The Norwegian Water Resources and Energy Directorate.

NVE, 2008. Vindkraftpotensialet utenfor norskekysten. The Norwegian Water Resources and Energy Directorate.

OPTRES, 2006. Report (D4) of the IEE project. Potentials and optimization of renewable electricity in Europe - The Green-X database on dynamic costresource curves. Intelligent Energy Europe.

Orkustofnun, 2006. Energy in Iceland. National Energy Authority of Iceland. 
Oy Vesirakentaja. 2007. Voimaa vedestä 2017. Selvitys vesivoiman lisäämismahdollisuuksista. Ministry of Trade and Employment.

Pfaffenberger, W. et al. 2006. Renewable energies - environmental benefits, economic growth and job creation. Case Study Paper. Bremer energie institut.

Profu, 200. Tillgång på förnybar energy. En rapport om energi och miljömål, Underlagsrapport till ET 2007:21 Energi som miljömål.

Pöyry Energy Ltd, 2007a. Tuulivoimatavoitteiden toteutumisnäkymät Suomessa - Päivitetty tilannekatsaus. Ministry of Trade and Industry.

Pöyry Energy Ltd, 2007b. Puupolttoaineiden kysyntä ja tarjonta Suomessa vuonna 2020 - Päivitetty tilannekatsaus. Ministry of Trade and Industry.

Renewable electricity with green certificates, 2006. Fact sheet. Ministry of Sustainable Development. May, 2006.

Rintala et al. 2007. Arvio biomassan pitkän aikavälin hyödyntämismahdollisuuksista Suomessa. Kauppa- ja teollisuusministeriö.

Skilhagen, S.E. et al. 2008. Osmotic power - power production based on the osmotic pressure difference between waters with varying salt gradients. Desalination vol. 220 (2008) pp. 476-482.

Statistics Finland, 2008. Energy supply, consumption and prices.

http://www.tilastokeskus.fi/til/ehkh/in dex_en.htm l [24.3.2008]

Statkraft, 2006. Osmotic Power - A huge renewable energy source.

STEM, 2007. Electrificatsystemet 2007. Swedish Energy Agency.

Sweko Grøner for ENOVA SF, 2007.

Potensialstudie av havenergi i Norge. Toke, D. 2007. Renewable financial support systems and costeffectiveness. Journal of Cleaner Production. Vol. 15. pp. 280-287.

Tolonen J. et al, 2006. Support schemes for renewable energy in the Nordic countries - an introduction. Ten Perspectives on Nordic Energy. Final report for the first phase of the Nordic Energy Perspectives project. Chapter 9.

Wene, C. 1999. Experience curves: measuring the performance of the black box. In: Wene, C.-O., Voss, A., Fried, T., (Eds.),Proceedings of the
IEA Workshop on Experience Curves for Policy Making - the Case of Energy Technologies, 10-11 May 1999, Stuttgart, Germany, p. 53.

VTT 2005. Skenaario ilmastopolitiikan vaikutuksista energiatalouteen. Working papers 36.

VTT, 2005. Liikenteen biopolttoaineiden tuotanto- ja köyttömahdollisuudet Suomessa.

VTT, 2005. Ruokohelven kättökapasiteettiselvitys. Maa- ja metsätalousminsteriö.

Värmeforsk, 2006. Biogas - Nuläge och framtida potential. Tvärteknik 993. Värmeforsk Service AB. 


\section{ANNEX 1.}

\section{Renewable energy in the Nordic countries}

According to preliminary data provided by the Danish Energy Authority $(2008)^{14}$ the total consumption of primary energy in Denmark amounted to $854 \mathrm{PJ}$ and electricity consumption amounted to $33 \mathrm{TWh}$ in 2007. As shown in Figure 10 the share of renewables in total consumption is around $16 \%$.

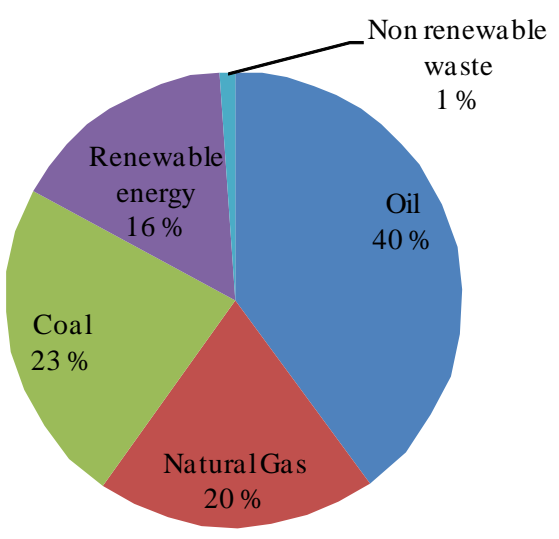

Figure 10 Energy consumption by source in Denmark 2007 (Danish Energy Authority, 2008).

In Finland the total consumption of primary energy amounted to 1.48 million TJ and consumption of electricity amounted to 90 TWh in 2007. The share of renewable energy in energy consumption is currently close to $29 \%$ as shown in Figure 11.

\footnotetext{
${ }^{14}$ Danish Energy Authority, 2008, Preliminary energy statistics for 2007. Data is available on line http://www.energistyrelsen.dk/sw16508.asp .
} 


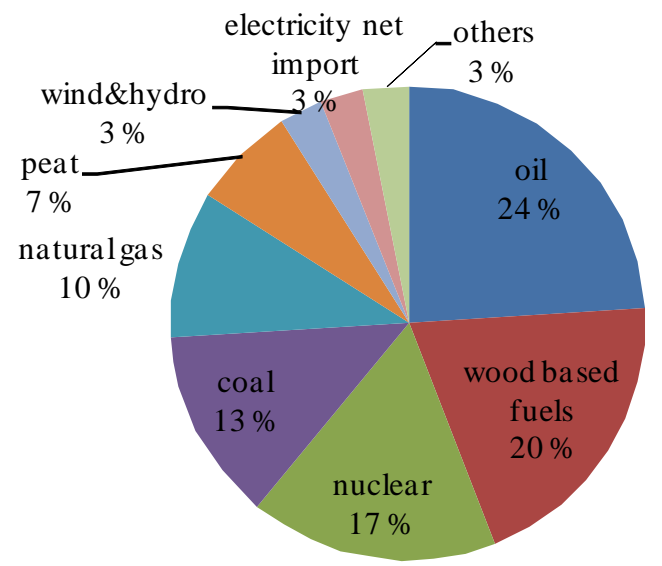

Figure 11 Energy consumption by source in Finland 2007 (Statistics Finland, 2008).

The total consumption of primary energy in Iceland amounted to 154.9 TJ and the consumption of electricity amounted to 9.9 TWh (35.6 TJ) in 2005. The share of domestic renewable energy sources has grown significantly in recent decades and in 2005 amounted to over $71 \%$ of total energy consumption. Fossil fuels are utilised mainly in industrial use and only a small amount is used in power production. Figure 12 shows the share of each source in Iceland's energy consumption.

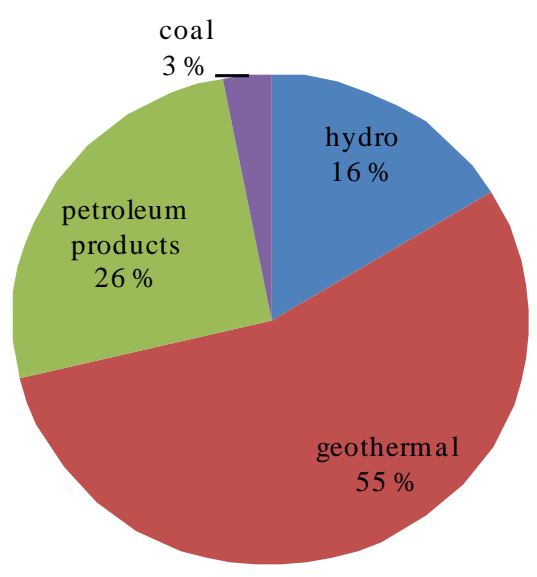

Figure 12 Energy consumption by source in Iceland 2005.

The total consumption of primary energy in Norway amounted to $803 \mathrm{PJ}$ (223 TWh) in $2005^{15}$. Consumption of electricity amounted to $128 \mathrm{TWh}$. The share of renewable energy in total energy consumption remained on same level with the year before with a share of $99 \%$. Figure 13 presents the percentual share of each energy source in total consumption.

\footnotetext{
${ }^{15}$ Statistics Norway, available on line http://www.ssb.no/english/subjects/01/03/10/energi_en/
} 


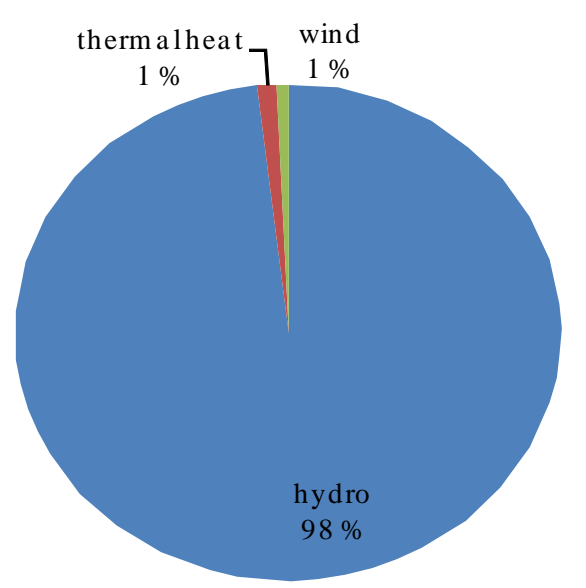

Figure 13 Share of renewable energy on total energy consumption in Norway 2007.

The total consumption of primary energy in Sweden amounted to 407 TWh and total use of electricity amounted to 135 TWh in 2006. The share of renewable energy is around $40 \%$ as shown in Figure 14 below.

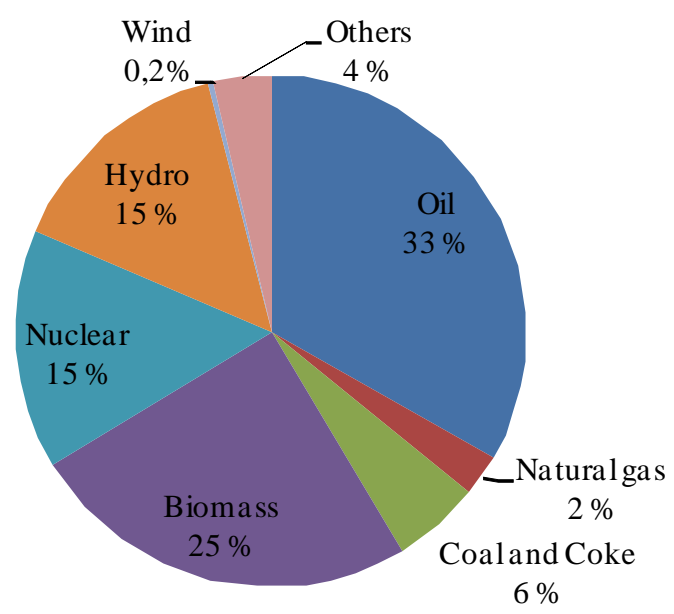

Figure 14 Share of renewable energy on total energy consumption in Sweden 2006. 


\section{ANNEX 2.}

\section{Renewable energy potential and costs in Iceland}

As a non member of the European Union, Iceland does not have a similar target for RES compared to the EU Member countries. A vast of Iceland's energy consumption relies already on renewable energy sources.

Electricity production based on renewable sources is already at $100 \%$ of consumption. In 2007, the total electricity generation was 11.976 GWh, thereof $70,1 \%$ from hydro power and $29,9 \%$ from geothermal. In 2009 , the total production is forecast to be about $15,000 \mathrm{GWh}$, with $20 \%$ generated in geothermal plants. At the same time, $80 \%$ of the electricity will be used in the energy intensive industry.

However, it is reasonable to assume that Iceland through the EEA agreement will have to take on a challenging target as well.

Currently 89 \% of Iceland's energy used for space heating is geothermal energy but with further research this could reach $95 \%$. Today, $10 \%$ of space heating is from electric boilers and only $1 \%$ of space heating has its origin from oil, mainly in isolated places where there is no access to the electric national grid.

The current utilization of geothermal energy for heating and other direct uses is considered to be only a small fraction of what this resource can provide.

For the potential generation of electricity, these energy reserves are estimated at roughly 50 TWh per year, some $60 \%$ coming from hydropower and $40 \%$ from geothermal resources.

In theory, the potential for RES-E production increase in Iceland is substantial. Due to a vast amount of hydro and geothermal potential available in Iceland, increase potentials for other sources such as wind tidal and wave energy are not thoroughly explored.

Due to geographical distance between Iceland and other Nordic countries that causes impossibilities that were discussed in Chapter 5, the Icelandic potential is not included but hence the analysis includes only Finland, Denmark, Norway and Sweden. 


\section{ANNEX 3.}

\section{Description for the calculation of the long-run marginal- costs}

In the references used in this study, the costs are presented in divergent units such as NOK/MWh, €/MWh, M€/MW, MNOK/MW or SEK/MWh. The costs are also calculated with different interest/calculation rates over a broad range of lifetimes. To compare or use these numbers directly is thus not possible but a harmonisation of the cost estimates was necessary to conduct in order to use them in the optimisation model. For inflation adjustment, data from the EUROSTAT-database ${ }^{16}$ has been utilised. Taxation and interest rate also vary in the Nordic countries. In this study some assumptions have been made in order to create the long-run marginal-costs (LRMC) for each country. However, the assumptions made are consistent ${ }^{17}$.

The prices for technology have been steadily increasing thus some of the estimates used can be considered as a lower limit of investment cost. ${ }^{18}$ It can be assumed that many of the largest Nordic power producers consider all countries with in the Nordic-region as their home market. Hence, the investment in a production facilities in any Nordic countries will be compared by a similar an investment calculations and estimates. Since the LRMC are used in an optimization model in this case, the level of the costs in each country is not important, but the relative difference between the countries. This is of course why we stress consistency in price over the level of price.

Table 10 The economic data behind the cost calculations.

\begin{tabular}{|c|c|c|c|c|c|}
\hline \multicolumn{6}{|c|}{ Economic fata for Nordic countries } \\
\hline Data/Country & Denmark & Finland & Iceland & Norway & Sweden \\
\hline Income tax & $28 \%$ & $26 \%$ & $18 \%$ & $28 \%$ & $28 \%$ \\
\hline Euribor interest rate & $6 \%$ & $6 \%$ & $6 \%$ & $6 \%$ & $6 \%$ \\
\hline Risk marginal & $6 \%$ & $6 \%$ & $12 \%$ & $6 \%$ & $6 \%$ \\
\hline$\overline{\mathrm{IRR}}$ & $12 \%$ & $12 \%$ & $12 \%$ & $12 \%$ & $12 \%$ \\
\hline Equity grade & $35 \%$ & $35 \%$ & $35 \%$ & $35 \%$ & $35 \%$ \\
\hline
\end{tabular}

\footnotetext{
${ }^{16}$ Data available on line http://epp.eurostat.ec.europa.eu

${ }^{17}$ The RES increase potentials presented in this study are based on existing studies thus the assumption made within these studies may vary.

${ }^{18}$ The development of cost for windmill-farms during the recent years can be viewed for example on the Norwegian Resources and Energy Directorate website. A Public document on this site indicates that the prices for wind-farms have increased from 9-10 MNOK/MW in 2006 to 12 MNOK/MW by the beginning of 2008. This indicates that cost estimates used in this study may be too low for the investment cost, but the LRMC are compensated upwards due to the conservative approach in calculation.
} 
Table 10 presents the data used for calculation of LRMC. The taxation levels are the same in Denmark, Norway and Sweden. Finland has $26 \%$ and Iceland is lowest on $18 \%$. Further a risk-free interest rate stands of 6 $\%$ has been assumed and a risk marginal of $6 \%$ for the loan capital. It can be assumed that larger companies will have a lower rate since they have a good credit rating but this is not likely to apply to smaller parties involved.

The internal rate of return (IRR) - that is return on the equity provided by the company itself - is assumed to be around $10 \%$. This takes into consideration the uncertainty in prices, produced volumes and in the development of costs of many technologies. In particular this is seen to apply for less mature technologies. Given the recent increase in investment costs, a high IRR together with a high lending rate will probably bring LRMC closer to at realistic level. Based on the lending-rate and IRR we have the found the weighted average cost for capital ${ }^{19}$ (WACC) based on an equity grad of $35 \%$.

The power price is set in $45 € / M W h$. Even though the price has increased within last months from 50 to 60 €/MWh it the base price in our calculation maintained the same. The aim of the calculation is to find LRMC, which in this case consist of the base price on $45 € / M W h$ and the support given in $€ / \mathrm{MWh}$, the only difference is that a higher base price will introduce is a lower support price. This would imply higher costs for consumers, since the main share of electricity still will be supplied from ordinary sources.

Given all the assumptions above, a simplified investment model was created. In the model it was assumed that the power price and operation costs are adjusted with inflation every year. Yearly inflation rate is assumed to be $2 \%$. The model heads to calculate the net present value for each technology in each country and find the support level which sets this value to zero. This support level is given in nominal values.

In theory, an investor should make an investment when net-present value is above zero. The target of the evaluation made in this study was not to make an investment decision but to find the long-run marginal-cost for each technology, and hence the net-present value equalling zero was the optimal solution. The solution is search for both low and high investment/operating costs thus results the lower and upper limit for LRMC for each technology, in each Nordic country.

Figure 15 gives a more schematic description and summarises the steps for how the LRMCs are found, and how the assumptions made within the study affects the LRMC used in this report.

\footnotetext{
${ }^{19}$ http://www.investopedia.com/terms/w/wacc.asp
} 
- Chose technology, that is wind, hydro, bio, or R \&D. In our m odel there is a m ore detailed splitting of technologies.

- Find average rate for a vailability (fullload hours) that applies for this technology.

Technology

parameters

- Find investm ent andO\&M costsf or this technology, m ost of them orginate from the OPTRES-report.

$\checkmark$

Decide on

economical

parameters

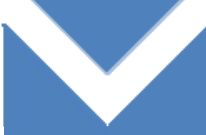

Intermediate

calculations

- Convert all costs and prices in to euro values.

- If prices given in other than nominell 2008 prices, a djust them with historic al inflation of each(relevart) coutrry. That is if prices are from 2005 , inflationa djust them up to 2008 .

Figure 15 A description of the SRMC calculation process

The process is repeated for each technology in each country, if relevant. Together with relevant potential for each technology, these prices and potentials then constitute the cost curves within the Nordic region. In absolute terms, some of the values may not be entirely accurate, but as stated before, they are consistent, and in an optimization model, that is enough to yield sufficient results. This since the relative difference between is assumed to be consistent.

It's also worth noticing that hydro power, in general, has LRMC that is far below other technologies and hence whether the potential is fully utilized is dependent on other factors. This applies also for some parts of the low-cost bio potential when compared with LRMC of wind-mills.

The relative difference between wind power potentials within the Nordic-region is a focal question in this context. The estimate for Norway is assumed to be in line with what new application of concession for wind-farms are stating. Following this, the accuracy of the figures is estimated to be good enough to examine the principal effects Nordic harmonisation has.

Finally, Table 11 presents the used investment and operation and maintenance costs for each technology in each country. 
Table 11 The investment and O\&M costs for technologies

\begin{tabular}{|c|c|c|c|c|c|c|c|c|c|c|}
\hline Country & Technology & $\begin{array}{c}\text { Availabilit } \\
\text { y rate }\end{array} \mid$ & $\begin{array}{l}\text { Investment } \\
\text { cost } € / \mathrm{kW} \\
\text { low }\end{array}$ & $\begin{array}{c}\text { Investment } \\
\text { cost } € / \mathrm{kW} \\
\text { high }\end{array}$ & $\begin{array}{c}\text { O\& M } \\
\text { cost } \\
\epsilon / \mathrm{kW}^{*} \text { year } \\
\text { low }\end{array}$ & $\begin{array}{c}\text { O \& M cost } \\
€ / \mathrm{kW}^{*} \text { year } \\
\text { high }\end{array}$ & $\begin{array}{c}\text { Estimated } \\
\text { potential } \\
\text { TWh }\end{array}$ & $\begin{array}{c}\text { Estimated } \\
\text { potential } \\
\text { MW }\end{array}$ & Reference for $0 \& M$ cost & Reference for invesment costs \\
\hline \multirow{7}{*}{ 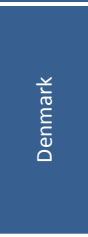 } & Onshore wind & 0,22 & 1330 & 1436 & 40 & 40 & 2,76 & 1432 & Optres, 2006 & Elforsk, 2008 \\
\hline & Offshore wind & 0,34 & 1915 & & 65 & & 9,38 & 3149 & Optres, 2006 & Elforsk, 2008 \\
\hline & Biomass & 0,30 & 550 & 4200 & 55 & 165 & 4,01 & 1526 & Optres, 2006 & Optres, 2006 \\
\hline & Biogas & 0,30 & 1500 & 4500 & 55 & 175 & 1,65 & 628 & Optres, 2006 & Optres, 2006 \\
\hline & Recyled material & 0,30 & 4300 & 6130 & 90 & 90 & 0,30 & 114 & Optres, 2006 & Optres, 2006 \\
\hline & Photovoltic & 0,30 & 5080 & 5930 & 38 & 47 & 0,50 & 190 & Optres, 2006 & Optres, 2006 \\
\hline & Wave & 0,25 & 2200 & 2800 & 44 & 53 & 0,10 & 46 & Optres, 2006 & Optres, 2006 \\
\hline \multirow{9}{*}{ 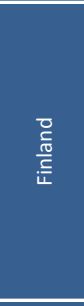 } & Onshore wind & 0,30 & 1330 & 1436 & 40 & 40 & 1,83 & 696 & Optres, 2006 & Elforsk, 2008 \\
\hline & Offshore wind & 0,34 & 1649 & 1915 & 65 & 65 & 4,27 & 1434 & Optres, 2006 & Elforsk, 2008 \\
\hline & Forest biomass & 0,30 & \multicolumn{4}{|c|}{ 43-78 } & 2,70 & 1027 & Optres, 2006 & Finnish Energy industries, 2007 \\
\hline & Straw & 0,30 & \multirow{2}{*}{\multicolumn{4}{|c|}{$\begin{array}{c}43-78 \\
103-137\end{array}$}} & 0,90 & 342 & Optres, 2006 & Finnish Energy industries, 2007 \\
\hline & Reed canary grass & 0,30 & & & & & 0,60 & 228 & Optres, 2006 & Optres, 2006 \\
\hline & Biogas & 0,30 & 1990 & 4500 & 55 & 145 & 0,80 & 304 & Optres, 2006 & Optres, 2006 \\
\hline & Recyled material & 0,30 & 4300 & 6130 & 90 & 90 & 1,30 & 495 & Optres, 2006 & Optres, 2006 \\
\hline & Large hydro & 0,50 & 800 & 3600 & 35 & 35 & 1,33 & 304 & Optres, 2006 & Optres, 2006 \\
\hline & Photovoltic & 0,30 & 5080 & 5930 & 38 & 47 & 0,10 & 38 & Optres, 2006 & Optres, 2006 \\
\hline \multirow{3}{*}{$\begin{array}{l}\frac{0}{0} \\
\underline{0} \\
\underline{\mathbb{E}}\end{array}$} & Geothermal & 0,30 & 2000 & 3500 & 100 & 170 & 17,60 & 6697 & Optres, 2006 & Optres, 2006 \\
\hline & Onshore wind & 0,30 & 1330 & 1505 & 40 & 40 & 1,00 & 381 & Optres, 2006 & Elforsk, 2008 \\
\hline & Large hydro & 0,50 & 850 & 3650 & 35 & 35 & 17,98 & 4105 & Optres, 2006 & Optres, 2006 \\
\hline \multirow{8}{*}{$\begin{array}{l}\frac{\pi}{2} \\
\frac{0}{2}\end{array}$} & Small hydro & 0,40 & 876 & 2190 & 40 & 40 & 18,00 & 5137 & Optres, 2006 & Blåfall AS, Lysakertorg 8,1366 Lysaker Norway \\
\hline & Large hydro & 0,50 & 800 & 3600 & 35 & 55 & 3,00 & 685 & Optres, 2006 & Optres, 2006 \\
\hline & Biomass & 0,30 & 251 & 2031 & 80 & 80 & 0,50 & 190 & Optres, 2006 & GSN estimate based on NVE, 2004b \\
\hline & Tidal & 0,25 & 2670 & 2670 & 44 & 44 & 1,00 & 457 & Optres, 2006 & Optres, 2006 \\
\hline & Onshore wind & 0,30 & 1330 & 1505 & 40 & 40 & 52,56 & 20000 & Optres, 2006 & Elforsk, 2008 \\
\hline & Offshore wind & 0,34 & 1649 & 1915 & 65 & 65 & 59,57 & 20000 & Optres, 2006 & Elforsk, 2008 \\
\hline & Osmotic & 0,79 & 5500 & 6000 & 68 & 68 & 12,00 & 1734 & $\begin{array}{c}\text { GSN estimate based on Skilhagen, et al 2008; } \\
\text { Optres, } 2006\end{array}$ & GSN estimate based on Skilhagen S E, et al. 2008 \\
\hline & Wave & 0,20 & 2850 & 2850 & 53 & 53 & 12,00 & 6849 & Optres, 2006 & Optres, 2006 \\
\hline \multirow{9}{*}{ 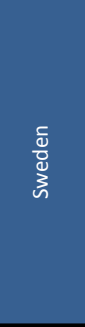 } & Onshore wind & 0,30 & 1330 & 1436 & 40 & 40 & 20,00 & 7610 & Optres, 2006 & Elforsk, 2008 \\
\hline & Offshore wind & 0,34 & 1649 & 1915 & 65 & 65 & 10,00 & 3358 & Optres, 2006 & Elforsk, 2008 \\
\hline & Biogas & 0,30 & 1500 & 4500 & 55 & 175 & 0,70 & 266 & Optres, 2006 & Elforsk, 2008 \\
\hline & Recyled material & 0,30 & 4300 & 6130 & 90 & 90 & 1,08 & 411 & Optres, 2006 & Optres, 2006 \\
\hline & Large hydro & 0,50 & 800 & 3600 & 35 & 35 & 3,00 & 685 & Optres, 2006 & Optres, 2006 \\
\hline & Small hydro & 0,40 & 800 & 1600 & 40 & 40 & 2,00 & 571 & Optres, 2006 & Optres, 2006 \\
\hline & Biomass, existing capacity & 0,30 & \multicolumn{4}{|c|}{ 43-137 } & 9,00 & 3425 & \begin{tabular}{|c|} 
Optres, 2006 and Finnish energy Industries, \\
2007
\end{tabular} & Optres, 2006 \\
\hline & Biomass, new capacity required & 0,30 & 1000 & 2400 & 80 & 165 & 8,49 & 3231 & Optres, 2006 & Optres, 2006 \\
\hline & Photovoltic & 0,30 & 5080 & 5930 & 38 & 47 & 1,50 & 571 & Optres, 2006 & Optres, 2006 \\
\hline
\end{tabular}




\section{ANNEX 4.}

Optimisation model description 
OPTIMISATION MODEL FOR A FREE MARKET SOLUTION

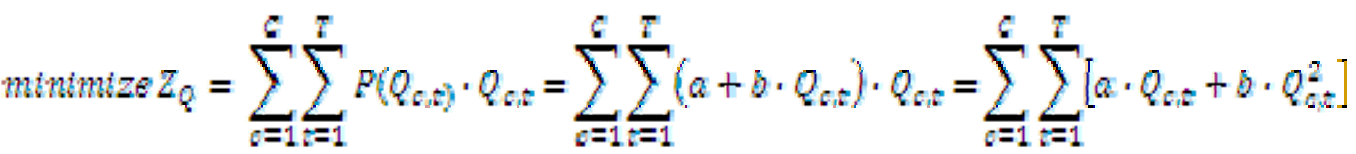

Subject to:

Production level must be larger than zero:

$\mathrm{Q}_{\mathrm{c}, \mathrm{t}}$ : Production in country $\boldsymbol{c}$, by technology $\boldsymbol{t}$.

(1) $Q_{o t} \geq 0\left\{\begin{array}{l}\epsilon=1,2,3,4 \text { (countryindex) } \\ t=1,2, \ldots 14,15 \text { (technologyindex) }\end{array}\right.$ non-negativityrestmetions

Production cannot exceed potential within the country for each technology:

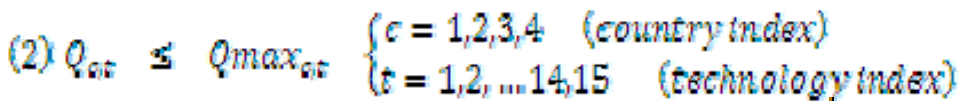

\section{RES-E-Target:}

Qtot : Total RES-E target within the Nordic region, Iceland excluded.

(3) $\sum_{i=1}^{0=4 t=18} \sum_{t=1}^{t=0} Q_{t a t}$

\section{OPTIMISATION MODEL FOR A NON-HARMONISED MARKET}

This model is similar to the free market model but with an additional restriction that RES-E target for each country must be satisfied. Thus is restriction (3) is replaced with restriction (3.1) since the new restriction also ensures that restriction (3) is satisfied.

\section{RES-E-Target for individual countries:}

Qtot $_{\mathrm{c}}$ : RES-E target for each country in the Nordic region, excluding Iceland.

(3.1) $\sum_{t=1}^{i=18} Q_{0:}=Q_{0} \quad \forall C$ 


\section{ANNEX 5.}

Sensitivity analysis 


\begin{tabular}{|c|c|c|c|c|c|c|}
\hline \multicolumn{7}{|c|}{$\begin{array}{c}\text { Base case } \\
\text { Segregated marked solution }\end{array}$} \\
\hline & Hydro & Wind & Bio & $R \& D$ & Total [TWh] & Share \\
\hline Denmark & 0,00 & 0,00 & 1,48 & 0,00 & 1,48 & $2,4 \%$ \\
\hline Finland & 0,66 & 0,80 & 4,09 & 0,00 & 5,54 & $8,8 \%$ \\
\hline Norway & 14,71 & 9,26 & 0,38 & 6,28 & 30,64 & $48,8 \%$ \\
\hline Sweden & 3,47 & 8,78 & 12,89 & 0,00 & 25,13 & $40,0 \%$ \\
\hline \multicolumn{7}{|c|}{$\begin{array}{l}\text { Scenario } 1 \text { : Low wind } \\
\text { Wind in Norway and Sweden is decreased to } 20 \mathrm{TWh}\end{array}$} \\
\hline & Hydro & Wind & Bio & R \& D & Total [TWh] & Share \\
\hline Denmark & 0,00 & 0,00 & 1,48 & 0,00 & 1,48 & $2,4 \%$ \\
\hline Finland & 0,66 & 0,83 & 4,09 & 0,00 & 5,57 & $8,9 \%$ \\
\hline Norway & 14,71 & 9,24 & 0,38 & 6,28 & 30,62 & $48,8 \%$ \\
\hline Sweden & 3,47 & 8,77 & 12,89 & 0,00 & 25,13 & $40,0 \%$ \\
\hline \multicolumn{7}{|c|}{$\begin{array}{l}\text { Scenario } 2 \text { : Extreme scenario with } 15 \text { TWh wind in Norway and Sweden. } \\
\text { Potential for small hydro in Norway decreased to } 10 \mathrm{TWh}\end{array}$} \\
\hline & Hydro & Wind & Bio & R \& D & Total [TWh] & Share \\
\hline Denmark & 0,00 & 0,00 & 1,48 & 0,00 & 1,48 & $2,4 \%$ \\
\hline Finland & 1,24 & 1,83 & 4,09 & 0,00 & 7,15 & $11,4 \%$ \\
\hline Norway & 12,84 & 7,01 & 0,38 & 6,28 & 26,51 & $42,2 \%$ \\
\hline Sweden & 4,76 & 10,00 & 12,89 & 0,00 & 27,65 & $44,0 \%$ \\
\hline \multicolumn{7}{|c|}{ Scenario 3 : Wind potential in Finland increased to $10 \mathrm{TWh}$} \\
\hline & Hydro & Wind & Bio & $\mathrm{R} \& \mathrm{D}$ & Total [TWh] & Share \\
\hline Denmark & 0,00 & 0,00 & 1,48 & 0,00 & 1,48 & $2,4 \%$ \\
\hline Finland & 0,66 & 2,30 & 4,09 & 0,00 & 7,04 & $11,2 \%$ \\
\hline Norway & 14,71 & 8,49 & 0,38 & 6,28 & 29,87 & $47,6 \%$ \\
\hline Sweden & 3,47 & 8,05 & 12,89 & 0,00 & 24,40 & $38,9 \%$ \\
\hline \multicolumn{7}{|c|}{ Scenario 4 : Increased RES-target for Norway to $10 \mathrm{TWh}$} \\
\hline & Hydro & Wind & Bio & $\mathrm{R} \& \mathrm{D}$ & Total [TWh] & Share \\
\hline Denmark & 0,00 & 0,00 & 1,78 & 0,00 & 1,78 & $2,6 \%$ \\
\hline Finland & 0,71 & 0,87 & 4,30 & 0,00 & 5,87 & $8,7 \%$ \\
\hline Norway & 16,05 & 10,00 & 0,45 & 6,78 & 33,28 & $49,1 \%$ \\
\hline Sweden & 3,58 & 9,47 & 13,82 & 0,00 & 26,87 & $39,6 \%$ \\
\hline \multicolumn{7}{|c|}{$\begin{array}{l}\text { Scenario } 5 \text { : Increased Nordic RES-target with } 20 \% \\
\text { Increase is applied for each country's target on a percentual basis. }\end{array}$} \\
\hline & Hydro & Wind & Bio & R \& D & Total [TWh] & Share \\
\hline Denmark & 0,00 & 0,00 & 2,27 & 0,00 & 2,27 & $3,0 \%$ \\
\hline Finland & 0,79 & 0,91 & 4,50 & 0,00 & 6,19 & $8,2 \%$ \\
\hline Norway & 18,07 & 11,14 & 0,50 & 7,54 & 37,25 & $49,4 \%$ \\
\hline Sweden & 3,75 & 10,56 & 15,34 & 0,00 & 29,65 & $39,3 \%$ \\
\hline \multicolumn{7}{|c|}{$\begin{array}{l}\text { Scenario } 6 \text { : Decreased Nordic RES-target with } 20 \% \\
\text { Decrease is applied to each country's target on a percentual basis. }\end{array}$} \\
\hline & Hydro & Wind & Bio & R \& D & Total [TWh] & Share \\
\hline Denmark & 0,00 & 0,00 & 2,08 & 0,00 & 2,08 & $4,1 \%$ \\
\hline Finland & 0,77 & 0,88 & 4,05 & 0,00 & 5,70 & $11,3 \%$ \\
\hline Norway & 10,74 & 7,19 & 0,50 & 5,02 & 23,45 & $46,7 \%$ \\
\hline Sweden & 3,56 & 7,01 & 8,44 & 0,00 & 19,01 & $37,8 \%$ \\
\hline
\end{tabular}




\section{ANNEX 6.}

\section{Harmonisation - Comparison on instruments}

\begin{tabular}{|c|c|c|c|}
\hline & Green Certificate & $\begin{array}{l}\text { Fixed feed-in- } \\
\text { tariff }\end{array}$ & $\begin{array}{l}\text { Premium feed-in- } \\
\text { tariff }\end{array}$ \\
\hline \multicolumn{4}{|l|}{ POLITICAL } \\
\hline -What has to be agreed & $\begin{array}{l}\text { The quota or obliga- } \\
\text { tion level }(\%)\end{array}$ & $\begin{array}{l}\text { Tariff level for } \\
\text { various } \\
\text { technologies. } \\
\text { What level is } \\
\text { sufficient to } \\
\text { encourage } \\
\text { new invest- } \\
\text { ments? }\end{array}$ & $\begin{array}{l}\text { Premium level for } \\
\text { various technolo- } \\
\text { gies. What level } \\
\text { is sufficient to } \\
\text { encourage new } \\
\text { investments? }\end{array}$ \\
\hline -Funding & & $\begin{array}{l}\text { How the } \\
\text { funding of the } \\
\text { tariff is divided } \\
\text { e.g. are the } \\
\text { costs divided } \\
\text { equally } \\
\text { between the } \\
\text { TSO's or } \\
\text { countries? }\end{array}$ & $\begin{array}{l}\text { Would the } \\
\text { countries provide } \\
\text { funding according } \\
\text { their RE targets } \\
\text { or based on the } \\
\text { production? }\end{array}$ \\
\hline $\begin{array}{l}\text {-Possibility to adjust system to take } \\
\text { into account local aspects }\end{array}$ & $\begin{array}{l}\text { Banding of certifi- } \\
\text { cates possible but } \\
\text { there is limited } \\
\text { experience of the } \\
\text { impacts of banding. }\end{array}$ & $\begin{array}{l}\text { Possibility to } \\
\text { introduce also } \\
\text { area specific } \\
\text { tariffs. }\end{array}$ & $\begin{array}{l}\text { Possibility to } \\
\text { introduce also } \\
\text { area specific } \\
\text { tariffs. }\end{array}$ \\
\hline \multicolumn{4}{|l|}{$\begin{array}{l}\text { IMPLEMENTATION\& } \\
\text { ADMINISTRATION }\end{array}$} \\
\hline -Main implementation challenges & $\begin{array}{l}\text { Establishing a } \\
\text { common registry, } \\
\text { registration of the } \\
\text { eligible plants, } \\
\text { monitoring and } \\
\text { verification. }\end{array}$ & $\begin{array}{l}\text { Defining } \\
\text { which entity } \\
\text { pays the tariff. } \\
\text { TSO's might } \\
\text { have different } \\
\text { legal roles } \\
\text { and conse- } \\
\text { quently } \\
\text { possibilities to } \\
\text { pay the tariff } \\
\text { and collect } \\
\text { payments } \\
\text { from for } \\
\text { example the } \\
\text { grid con- } \\
\text { nected users. }\end{array}$ & $\begin{array}{l}\text { Defining which } \\
\text { entity pays the } \\
\text { tariff. TSO's } \\
\text { might have } \\
\text { different legal } \\
\text { roles and conse- } \\
\text { quently possibili- } \\
\text { ties to pay the } \\
\text { tariff. If the } \\
\text { system is funded } \\
\text { from the govern- } \\
\text { mental budgets, } \\
\text { guaranteeing the } \\
\text { funding in long- } \\
\text { term might be } \\
\text { challenging. }\end{array}$ \\
\hline -Operational challenges & $\begin{array}{l}\text { After the scheme is } \\
\text { implemented, main } \\
\text { administrative task } \\
\text { on issuing the } \\
\text { certificates and } \\
\text { supervision. Centra- } \\
\text { lized vrs. distributed } \\
\text { administration and } \\
\text { Supervision. }\end{array}$ & $\begin{array}{l}\text { Cost esti- } \\
\text { mates needed } \\
\text { in order to set } \\
\text { the fixed price } \\
\text { to the suffi- } \\
\text { cient level. } \\
\text { Possible } \\
\text { adjustments } \\
\text { in tariff level. }\end{array}$ & $\begin{array}{l}\text { Price forecasts } \\
\text { and cost esti- } \\
\text { mates needed in } \\
\text { order to establish } \\
\text { sufficient pre- } \\
\text { mium level. } \\
\text { Possible adjust- } \\
\text { ments of the } \\
\text { premium level. }\end{array}$ \\
\hline
\end{tabular}




\begin{tabular}{|c|c|c|}
\hline \multicolumn{3}{|l|}{ Market and actors } \\
\hline & $\begin{array}{l}\text { Harmonized green } \\
\text { certificate might be } \\
\text { more suitable for } \\
\text { large multinational } \\
\text { companies that } \\
\text { have many RE } \\
\text { sources in their } \\
\text { production portfolio }\end{array}$ & $\begin{array}{l}\text { Low risk } \\
\text { investment } \\
\text { opportunities } \\
\text { might lead to } \\
\text { inefficient } \\
\text { solution if } \\
\text { some of the } \\
\text { new invest- } \\
\text { ments would } \\
\text { be built in } \\
\text { unoptimal } \\
\text { locations. }\end{array}$ \\
\hline
\end{tabular}




\section{ANNEX 7.}

Viewpoint; torstein bye: harmonising instruments -why?

The main viewpoints of presentation by Torstein Bye, Statistics Norway, given in Workshop Nordisk harmonisering - utmaningar och möjligheter för fortsatta framsteg in Stockholm May $27^{\text {th }} 2008$.

Harmonisation - equal instruments or instrument equal marginal cost? Arguments for market intervention:

- negative externalities

- positive externalities

- other market imperfections

- global vs. local - on what level are we discussing

\section{Conclusions:}

- Harmonise when dealing with global issues ( GHGs)

- When local issues - in principle - do not harmonise

- Harmonised goals require harmonised instruments

- Subsidies implies costs and the benefits could be redistribute by trade (both domestic and international)

- Overall, no general answer can be given, details determine a lot.

By and large, Mr Bye highlighted that it is important to decide what the ultimate objective of the policy, before one can make accurate suggestion which policy measures to implement and that devil is always in the details. 


\section{ANNEX 8. interviewed stakeholders}

\begin{tabular}{|c|c|c|}
\hline Country & Organisation & Name \\
\hline \multirow[t]{5}{*}{ Denmark } & Danish Wind Turbine Owners' Association & Asbjørn Bjerre \\
\hline & Danish Wind Industry Association & Rune Moesgaard \\
\hline & Danish Energy Agency & Flemming G. Nielsen \\
\hline & DONG Energy & $\begin{array}{l}\text { Jonny Trapp Steffensen and Katja } \\
\text { Birr-Pedersen }\end{array}$ \\
\hline & Finnish Energy Industries & $\begin{array}{l}\text { Jukka Leskelä and Niina } \\
\text { Honkasalo }\end{array}$ \\
\hline \multirow{6}{*}{ Finland } & Wood Energy Association & Tage Fredrikson \\
\hline & ElFi Oy & Antti Koskelainen \\
\hline & Ministry of Employment and Economy & Erkki Eskola and Petteri Kuuva \\
\hline & Pohjolan Voima & Juha Poikola \\
\hline & Fortum Oyj & $\begin{array}{l}\text { Esa Hyvärinen and Kari } \\
\text { Kankaanpää }\end{array}$ \\
\hline & WBD & Esa Holttinen \\
\hline \multirow[t]{2}{*}{ Iceland } & Landsvirkjun & Unnur María Porvaldsdóttir \\
\hline & Orkustofnun, National Energy Authority & Ragnheiður Inga Pórarinsdóttir \\
\hline \multirow[t]{3}{*}{ Norway } & EBL Norwegian Electricity Industry Association & Hans Magne Ådland \\
\hline & $\overline{\mathrm{NVE}}$ & Mari Hegg Gundersen \\
\hline & $\underline{\text { Statkraft }}$ & Anne C Bolle \\
\hline \multirow[t]{5}{*}{ Sweden } & Svensk Energi & Maria Sunér Fleming \\
\hline & Svensk Vindkraft & Matthias Rapp \\
\hline & Tricorna/SMK & Peter Chudi \\
\hline & Vattenfall & Göran Svensson \\
\hline & STEM, Swedish Energy Agency & Lars Guldbrand \\
\hline
\end{tabular}




\section{ANNEX 9. stakeholder interview questions}

\section{Policy instruments}

- What is your opinion on the current RES policy in the country you are presenting?

- What have been the main advantages and disadvantages of the system

- How well does it encourage new investments

- Name the qualities that are most valued and what most unwanted in a renewable energy policy support system.

- What is your opinion on support mechanisms in general - what is their purpose in the country you are representing?

- How different RES technologies in different maturity stages should be taken into account?

\section{Nordic harmonisation}

a. How important is harmonisation - do you think it would bring real additional value to Nordic countries?

b. Is there enough realistic renewable energy potential in the country you are presenting for an effectively functioning policy mechanism (estimation for potential presented within the interview)?

c. Do you think a harmonised green certificate system would affect security of energy supply?

If yes, in what direction

If the affect is negative, in what level would this be considered critical?

d. On what level and time scale could positive and measurable impacts on labour be expected or is there any at all?

e. Green certificates versus Feed-in tariffs

f. Would an effective feed-in tariff system have a positive effect on investments in the short-run?

g. Which instruments would eventually support investments the best?

A green certificate system is likely to cause uneven distribution of investments - how do you see this would affect Sweden?

h. If there would be differing support systems in Nordic countries, how could these mechanisms (certificates, feed-in tariffs) be harmonised? 


\section{Outcome}

a. What harmonised policy mechanism would support best the RES target of the country you are presenting?

b. How do you see individual countries and companies would be affectted by harmonised policy instrument - winners and losers?

c. What are the main possible benefits and risks in a harmonised system in general?

d. Are some of these emphasised under green certificate system or feedin tariffs?

e. What would be your choice for an instrument and reasons for your choice? 


\section{ANNEX10. Interview results - summary}

\begin{tabular}{|c|c|c|c|}
\hline $\begin{array}{l}\text { Respon- } \\
\text { dent }\end{array}$ & what is their purpose & what is valued & what is unwanted \\
\hline 㝵 & $\begin{array}{l}\text { - Are needed in order to ensure new } \\
\text { investments to RES }\end{array}$ & $\begin{array}{l}\text { + Predictability } \\
\text { + Long time scope } \\
\text { + Stability }\end{array}$ & $\begin{array}{ll}\text { - } & \text { Uncertainty } \\
- & \text { Unpredictability } \\
\text { - } & \text { Short time scope }\end{array}$ \\
\hline 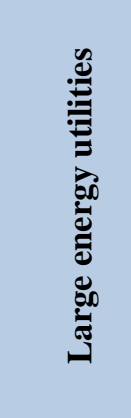 & $\begin{array}{l}\text { - Support can be justified if its objective } \\
\text { is clear and imperfections in the market } \\
\text { exist. }\end{array}$ & $\begin{array}{l}\text { + Technology neutral to ensure the cost- } \\
\text { efficiency of the investments. } \\
\text { + Includes risk aspect } \\
\text { + Must gain necessary confidence to meet the } \\
\text { target } \\
\text { + Long term rules which create conditions for } \\
\text { investors } \\
\text { + Market based } \\
\text { + Must provide sufficient support for risky } \\
\text { renewable (wind) }\end{array}$ & $\begin{array}{l}\text { - Fixed price regulation with detailed re-regulation to } \\
\text { follow the market development. } \\
\text { - National approach } \\
\text { - Hiding subsides } \\
\text { - Technology out of the market } \\
\text { - Administrative decisions }\end{array}$ \\
\hline 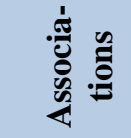 & $\begin{array}{l}\text { - The demand from the market should be } \\
\text { the only base for development. }\end{array}$ & $\begin{array}{l}\text { + Technology neutrality } \\
\text { + Market based } \\
\text { + Sufficient stability }\end{array}$ & $\begin{array}{l}\text { - Promotion of specific technologies } \\
\text { - Short sighted } \\
\text { - Different support levels for same technology }\end{array}$ \\
\hline 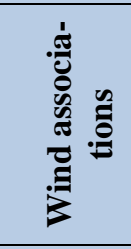 & $\begin{array}{l}\text { - Need to have a frame and security on } \\
\text { pricing to support new investments. }\end{array}$ & $\begin{array}{l}\text { + The system brings new capacity as was } \\
\text { planned when creating the system } \\
\text { + Perseverance }\end{array}$ & $\begin{array}{l}\text { - unequal treatment for parties, protection of current } \\
\text { players } \\
\text { - blocking the market for new entrants } \\
\text { - minimizing the amount of support in the name of " } \\
\text { not letting private investors to make profit with pub- } \\
\text { lic money" }\end{array}$ \\
\hline . & $\begin{array}{l}\text { - Important that scheme has only one } \\
\text { goal at a time } \\
\text { - Helps new advantageous solutions (that } \\
\text { otherwise would be too risky) to the } \\
\text { market. }\end{array}$ & $\begin{array}{l}\text { + Technology neutral } \\
\text { + Market based } \\
\text { + Easy to administrate } \\
\text { + Understandable system and costs (citizen’s } \\
\quad \text { point of view) }\end{array}$ & $\begin{array}{l}\text { - Should not be technology specific and dependent on } \\
\text { government designed support levels } \\
\text { - Changing schemes } \\
\text { - Artificial limits that lead to sub-optimization. }\end{array}$ \\
\hline
\end{tabular}




\begin{tabular}{|c|c|c|c|}
\hline & \multicolumn{3}{|c|}{ ON A HARMONISED SUPPORT MECHANISM: } \\
\hline Respondent & - Green certificates & Feed-in tariffs & National perspective \\
\hline 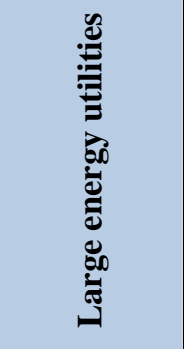 & $\begin{array}{l}\text { - Risk is and should always be involved in } \\
\text { business, if it is taken a way it is no longer } \\
\text { business, no is that threat } \\
\text { - A certificate system would bring the cheap } \\
\text { capacity to the markets, tariffs all kind of } \\
\text { production. }\end{array}$ & $\begin{array}{l}\text { - Brings new investments but not efficient in the } \\
\text { long run. } \\
\text { - No possibility for price adjusting based on sup- } \\
\text { ply and demand } \\
\text { - If technology specific, no competition between } \\
\text { technologies } \\
\text { - Feed -ins are a production support that har- } \\
\text { monisation does not benefit }\end{array}$ & $\begin{array}{l}\text { - Coherent thinking is needed; we have a common market } \\
\text { with ETS, why should we think differently with RES pol- } \\
\text { icy? }\end{array}$ \\
\hline 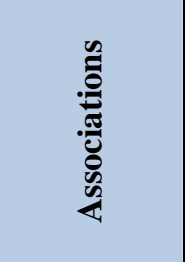 & $\begin{array}{l}\text { - Most important benefit s the cost effective- } \\
\text { ness for consumer and improved price set- } \\
\text { ting and trading when bigger market. } \\
\text { - Problem with in green certificate; the cer- } \\
\text { tificate price does not follow the electricity } \\
\text { market price but leads to over/under sup- } \\
\text { port. }\end{array}$ & $\begin{array}{l}\text { - Would erase any market distortion due to dif- } \\
\text { ferent support level. } \\
\text { - } \quad \text { Feed-ins are more effective than certificates }\end{array}$ & $\begin{array}{l}\text { - If harmonisation brings fewer investments that only imply } \\
\text { that other countries can do the investment with lower cost } \\
\text { - which benefits all. And vice versa. } \\
\text { - National support schemes would assure that the produc- } \\
\text { tion will be built into the supporting country } \\
\text { - National RES potential and cost structure needs to be } \\
\text { considered. }\end{array}$ \\
\hline . & $\begin{array}{l}\text { - Efficient with resources } \\
\text { - leads to more sound investment } \\
\text { - In a way good but does not promote new } \\
\text { technology and const more for consumer if a } \\
\text { one level system. } \\
\text { - Certificate system is a bigger risk since it is } \\
\text { ideologically closer to free markets. }\end{array}$ & $\begin{array}{l}\text { - If support is generous will definitely lead to new } \\
\text { investments but would be expensive and lead to } \\
\text { production that requires permanent support. } \\
\text { - If there's enough support, investments will in- } \\
\text { crease. If a fixed tariff - it is not a RES market.. }\end{array}$ & $\begin{array}{l}\text { - If we have national targets we need national instruments. } \\
\text { - Support mechanism that would lead to investments in } \\
\text { other countries would be difficult to argued for politics } \\
\text { and public. }\end{array}$ \\
\hline
\end{tabular}




\begin{tabular}{|c|c|c|c|}
\hline \multicolumn{4}{|c|}{ NORDIC HARMONISATION: } \\
\hline Respondent & Best harmonised instrument & Pros for harmonisation & Cons for harmmmonisation \\
\hline 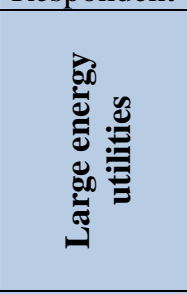 & $\begin{array}{l}\text { - Certificates } \\
\text { - An ideal situation is one, objective } \\
\text { support system } \\
\text { - Quota obligation system }\end{array}$ & $\begin{array}{l}\text { - Would enhance market liquidity } \\
\text { - high cost efficiency } \\
\text { - More efficient utilisation of natural and eco- } \\
\text { nomic resources, money would be saved. } \\
\text { - Would provide elasticity, can already be seen } \\
\text { with hydro which is be produced where it is } \\
\text { most profitable. }\end{array}$ & $\begin{array}{l}\text { - Full harmonisation not necessary, more important is } \\
\text { to openness across borders } \\
\text { - High price volatility in too small markets is a risk }\end{array}$ \\
\hline 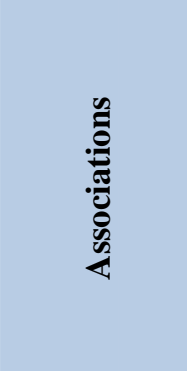 & $\begin{array}{l}\text { - Technology neutral certificate system } \\
\text { - From investor's point of view invest- } \\
\text { ment subsidy, but as such the chosen } \\
\text { instrument isn't the issue but how it is } \\
\text { exploited and what is the level of sup- } \\
\text { port } \\
\text { - best tool would be national invest- } \\
\text { ment support and auctioned feed-in } \\
\text { tariff system }\end{array}$ & $\begin{array}{l}\text { - Is the first step towards EU level harmonisa- } \\
\text { tion, that's why very important } \\
\text { - Would bring additional value for consumers. } \\
\text { - Would bring stability to the market. } \\
\text { - Increases liquidity and the most cost efficient } \\
\text { solutions would be triggered in the Nordic } \\
\text { area. }\end{array}$ & $\begin{array}{l}\text { - Harmonisation would not bring any extra benefits } \\
\text { but might lead to unwanted situations in national } \\
\text { level because generation structures, costs, and RES } \\
\text { obligations are different in countries. } \\
\text { - Harmonisation is not an issue, details matter. }\end{array}$ \\
\hline 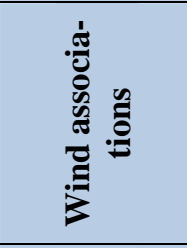 & $\begin{array}{l}\text { - Certificates' - based on the Swedish } \\
\text { system. } \\
\text { - National scheme is needed quickly } \\
\text { and discussion on harmonisation dis- } \\
\text { turbs it. }\end{array}$ & $\begin{array}{l}\text { - Would bring price stability with larger vol- } \\
\text { umes } \\
\text { - Would bring stability to the whole system } \\
\text { since changes would not be so easy to make. }\end{array}$ & $\begin{array}{l}\text { - It’s funny how a "market-based support system” } \\
\text { fails over and over again to create a functioning } \\
\text { market! } \\
\text { - Even discussing harmonisation at this stage prohib- } \\
\text { its all investments and freezes most of the project } \\
\text { development. }\end{array}$ \\
\hline 产 & $\begin{array}{l}\text { - Certificates } \\
\text { - A feed-in tariff differentiated for each } \\
\text { technology. Premium based would be } \\
\text { better for electricity market. }\end{array}$ & $\begin{array}{l}\text { - } \text { More efficient to have a level of playing field. } \\
\text { - } \quad \text { Market comp ability }\end{array}$ & $\begin{array}{l}\text { - More important to have harmonised standards and } \\
\text { product requirements that would enlarge the market } \\
\text { without barriers than harmonised support scheme. }\end{array}$ \\
\hline
\end{tabular}




\begin{tabular}{|c|c|c|c|}
\hline \multicolumn{4}{|c|}{ HARMONISATION AND NEW INVESTMENTS: } \\
\hline Respondent & Developing technologies & Markets & Winners and Losers \\
\hline 章 & $\begin{array}{l}\text { - Policy point: R\&D support is needed. If } \\
\text { technology is not mature enough to enter } \\
\text { market a R\&D program could be defined. }\end{array}$ & $\begin{array}{l}\text { - Consumer point: the cheapest should enter the } \\
\text { market first. } \\
\text { - For investors, most important is the size and sta- } \\
\text { bility of support } \\
\text { - A certificate system would brig the cheap capac- } \\
\text { ity to the markets, tariffs all kind of production. }\end{array}$ & $\begin{array}{l}\text { - One should not look the regional politics but the set target. } \\
\text { - Some distortion in investment is likely to occur but better } \\
\text { for the market in longer term. } \\
\text { - Winners are companies that hold the cheapest production } \\
\text { sites and all: less money spent on reaching the target } \\
\text { - Small companies may face disadvantages in a large market } \\
\text { - "If there's a common market the location of investments is } \\
\text { not a question. " }\end{array}$ \\
\hline 鄫 & $\begin{array}{l}\text { - Technologies that are in commercialisation } \\
\text { phases must have additional support. } \\
\text { - Basic principle should be that the newer } \\
\text { the technique, the higher the support. No } \\
\text { matter how it is directed. }\end{array}$ & $\begin{array}{l}\text { - The level of support defines the effect - not the } \\
\text { instrument used. In addition long term stability } \\
\text { must exsist. }\end{array}$ & - If a technology neutral system, there would be no losers. \\
\hline 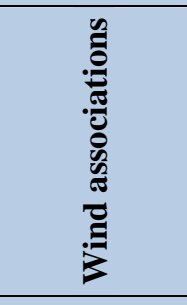 & $\begin{array}{l}\text { - Developing technologies that othervise } \\
\text { wouldn't enter the market should have a } \\
\text { separate feed-in system. } \\
\text { - Technology specific targets and support } \\
\text { levels should be applied in the first stage. } \\
\text { Not too much competition with different } \\
\text { technologies too early. For larger players it } \\
\text { is easier who can handle the risk. } \\
\end{array}$ & $\begin{array}{l}\text { - Pricing should be the same for all consumers. The } \\
\text { chosen instrument is not an issue but other condi- } \\
\text { tions define whether investments will occur. } \\
\text { - The one having the best business intelligence } \\
\text { should win, not the one who doesn't have a clue } \\
\text { on the business but has muscles big enough to } \\
\text { suffer the losses and elbow everyone else out. }\end{array}$ & $\begin{array}{l}\text { - Less new production for Denmark, Neutral position for } \\
\text { Sweden ad Finland; Norway would be the winner } \\
\text { - A harmonized market for RES would mean that most of } \\
\text { the wind investments would occur in Norway where you } \\
\text { have the best wind resource and lots of space available. } \\
\text { Other Nordic countries would voluntarily support the } \\
\text { Norwegian national economy. }\end{array}$ \\
\hline 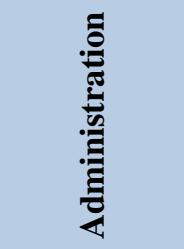 & $\begin{array}{l}\text { - Developing technologies require R\&D and } \\
\text { demonstration support. }\end{array}$ & $\begin{array}{l}\text { - Market based support for limited time-spans for } \\
\text { mature technologies. Large scale of technologies } \\
\text { that require support something between R\&D and } \\
\text { mature ones. }\end{array}$ & $\begin{array}{l}\text { - If a fully harmonised system, there would be winners in } \\
\text { every country. } \\
\text { - Actors who have access to cheap technology and technical } \\
\text { support. }\end{array}$ \\
\hline
\end{tabular}




\begin{tabular}{|c|c|c|c|}
\hline & \multicolumn{3}{|c|}{ IMPACTS OF HARMONISATION } \\
\hline Respondent & Labour & Security of Supply & Grid issue \\
\hline 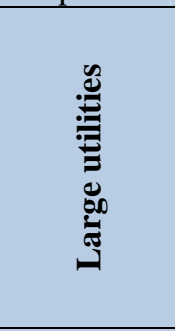 & - & 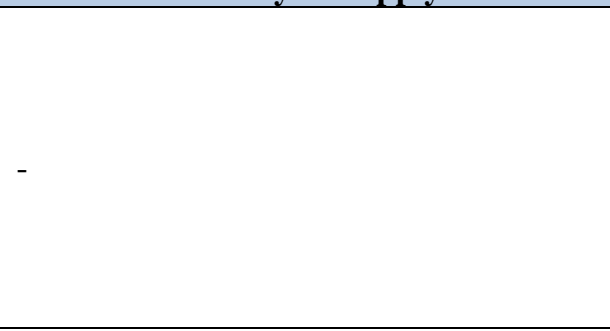 & $\begin{array}{l}\text { - Small producers and grid functionality? How } \\
\text { can be known whether it is long lasting, trou- } \\
\text { bles can follow, not considered from the mar- } \\
\text { ket point of view. } \\
\text { - Hydro and wind would be produced always } \\
\text { (wind conditions) despite the market, would } \\
\text { stiffen the functionality since there would be a } \\
\text { big bulk on the bottom. Obvious also in bio. }\end{array}$ \\
\hline 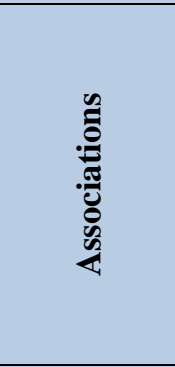 & $\begin{array}{l}\text { - New investments will have positive impact on } \\
\text { welfare and job opportunities will occur. Not } \\
\text { studied more closely. }\end{array}$ & $\begin{array}{l}\text { - In case the share of wind power in- } \\
\text { creases the need for regulation power } \\
\text { increases. In general, increasing produc- } \\
\text { tion mix improves security of supply. } \\
\text { - Everyone is currently counting on im- } \\
\text { port, someone should also export. The } \\
\text { truth is somewhere in the middle } \\
\text { - No nuclear plant will be closed because } \\
\text { of RES. }\end{array}$ & \\
\hline 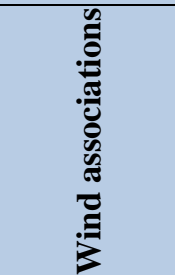 & - No recognisable connection & $\begin{array}{l}\text { - In Nordic level would increase the secu- } \\
\text { rity of supply. }\end{array}$ & $\begin{array}{l}\text { - Who shall carry the costs for grid extensions if } \\
\text { a harmonized support scheme }\end{array}$ \\
\hline 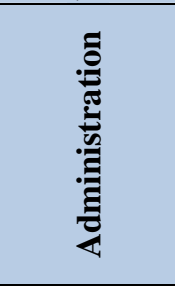 & $\begin{array}{l}\text { - Large impact expected only if a country takes } \\
\text { an internationally leading role in some area. } \\
\text { - Positive labour impact could in principle be } \\
\text { expected ifproduction and use increases. } \\
\text { Eventhoufh juridical obligation is fullfilled but } \\
\text { there's no local or employment effet the system } \\
\text { would be difficult to justify. }\end{array}$ & $\begin{array}{l}\text { - A diversification of supply should ha a } \\
\text { positive effect, regardless of the policy } \\
\text { instrument. }\end{array}$ & $\begin{array}{l}\text { - If leads to geographical distribution of produc- } \\
\text { tion might lead to lack of grid connections. }\end{array}$ \\
\hline
\end{tabular}




\begin{tabular}{|c|c|c|c|}
\hline & \multicolumn{3}{|c|}{ SPECIAL ISSUES: } \\
\hline Respondent & Policy & EU & Guarantees of origin \\
\hline 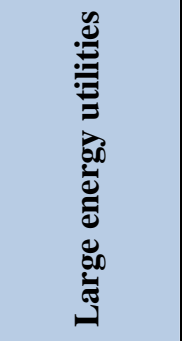 & $\begin{array}{l}\text { - A multi objective driven regulation } \\
\text { is very difficult to evaluate from the } \\
\text { efficiency point of view. } \\
\text { - "The whole subject is politically } \\
\text { oriented." }\end{array}$ & $\begin{array}{l}\text { - The objective of the RES directive is not clear. } \\
\text { - Emission reduction target should be prioritized } \\
\text { - We have EU-level targets; we should also have a } \\
\text { EU-wide support system. Not every country needs } \\
\text { to build new capacity, only those for who it is the } \\
\text { most beneficial. } \\
\text { - If there are different schemes in the EU, strange } \\
\text { consequences will follow. }\end{array}$ & $\begin{array}{l}\text { - Harmonised GoO would facilitate a harmo- } \\
\text { nized support scheme, bring flexibility and } \\
\text { promote the cheapest technologies. } \\
\text { - What is the status of Norway and GoOs, at the } \\
\text { moment is restricted so that the electricity } \\
\text { must be consumed within the EC - could not } \\
\text { trade with GoOs. }\end{array}$ \\
\hline 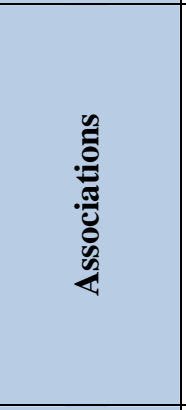 & $\begin{array}{l}\text { - Harmonisation would require } \\
\text { changing the Directive so that bur- } \\
\text { den sharing within Nordic countries } \\
\text { would be possible. At the moment } \\
\text { focus is too much in new capacity } \\
\text { (wind) bio fuels in a difficult posi- } \\
\text { tion. Several details have been } \\
\text { thought but the wholeness doesn't } \\
\text { work. Politicians should speak out } \\
\text { on this. }\end{array}$ & $\begin{array}{l}\text { - EU level harmonisation is the goal } \\
\text { - The time scope in EU ETS was a success - why not } \\
\text { also for harmonisation. If EU really heads for target } \\
\text { there will inevitably be distortion and EU level in- } \\
\text { tervention is needed. This means that harmonisation } \\
\text { would go through EU. }\end{array}$ & - \\
\hline 量 & $\begin{array}{l}\text { - Harmonisation requires a political } \\
\text { decision. }\end{array}$ & $\begin{array}{l}\text { - Possible harmonisation is connected to the outcome } \\
\text { of the RES Directive negotiations. }\end{array}$ & $\begin{array}{l}\text { - Focal is what the status of GoOs is; is the } \\
\text { transfer among countries or companies. If } \\
\text { transfer is not restricted would the investments } \\
\text { concentrate strongly? } \\
\text { - Can lead to "support competition" which } \\
\text { would eventually harmonise the support lev- } \\
\text { els. This affects whether it is possible to have } \\
\text { national schemes. }\end{array}$ \\
\hline
\end{tabular}

